University of Louisville

ThinkIR: The University of Louisville's Institutional Repository

Electronic Theses and Dissertations

$5-2013$

\title{
The feeling of faith : a Thomistic account of religious emotions.
}

John K. Dryden 1976-

University of Louisville

Follow this and additional works at: https://ir.library.louisville.edu/etd

\section{Recommended Citation}

Dryden, John K. 1976-, "The feeling of faith : a Thomistic account of religious emotions." (2013). Electronic Theses and Dissertations. Paper 373.

https://doi.org/10.18297/etd/373

This Doctoral Dissertation is brought to you for free and open access by ThinkIR: The University of Louisville's Institutional Repository. It has been accepted for inclusion in Electronic Theses and Dissertations by an authorized administrator of ThinkIR: The University of Louisville's Institutional Repository. This title appears here courtesy of the author, who has retained all other copyrights. For more information, please contact thinkir@louisville.edu. 
THE FEELING OF FAITH: A THOMISTIC ACCOUNT OF RELIGIOUS EMOTIONS

\author{
By \\ John Dryden \\ B.A., University of Louisville, 2000 \\ M.A., University of Louisville, 2003

\begin{abstract}
A Dissertation
Submitted to the Faculty of the

College of Arts and Sciences of the University of Louisville in Partial Fulfillment of the Requirements

for the Degree of
\end{abstract}

Doctor of Philosophy

Department of Humanities

University of Louisville

Louisville, Kentucky

May 2013 
Copyright 2013 by John Dryden

All rights reserved 

THE FEELING OF FAITH: A THOMISTIC ACCOUNT OF RELIGIOUS EMOTIONS

\author{
By \\ John Dryden \\ B.A., University of Louisville \\ M.A., University of Louisville
}

A Dissertation Approved on

April 19, 2013

by the following Dissertation Committee

Dr. Robert Kimball

Dissertation Director

Dr. Thomas Maloney

Dr. Mary Ann Stenger

Dr. Guy Dove 


\section{DEDICATION}

This dissertation is dedicated to my wife

\section{Julie Dryden}

whose sacrifice and encouragement made the completion of this project possible. 


\section{ACKNOWLEDGMENTS}

I would like to thank my dissertation advisor, Dr. Robert Kimball, for his guidance and thoughtful questions and comments. I would also like to express my gratitude to Dr. Thomas Maloney for introducing me to the brilliance of Thomas Aquinas in a way that only Dr. Maloney can. I cannot thank Dr. Stenger enough for being such an inspiration to me for many years. Also, many thanks to my parents and family who have always encouraged me to follow my calling, even if it did not always seem like the practical decision. Finally, I would like to thank my wife without whom I would be lost. 


\section{ABSTRACT \\ THE FEELING OF FAITH: A THOMISTIC ACCOUNT OF RELIGIOUS EMOTIONS \\ John Dryden}

April 19, 2013

This dissertation is a philosophical analysis of religious emotions. It draws upon Thomas Aquinas's theory of the passions to build and apply a framework for thinking about religious emotions and their role in the spiritual life. The first two chapters are dedicated to building the theoretical framework. Chapter one outlines Aquinas's theory of emotions in a very general way and compares this account to recent versions of cognitivism. By placing Aquinas in conversation with contemporary accounts, I show that his theory is able to capture the central insights of this mainstream philosophical view. According to the Thomistic account that emerges in this chapter, emotions are psychosomatic forms of concern. In the second chapter, I begin to outline what makes an emotion a religious emotion. Drawing on Robert Neville's theory of religious symbols, I suggest that religious emotions are emotions that have religious symbols interpreted in a devotional context ${ }^{1}$ as their object. With this account of religious emotions in hand, the next two chapters are dedicated to illustrating and applying this framework in a phenomenological and comparative mode. In chapter three, I apply the framework to illustrate its promise in highlighting common emotional patterns across religious

\footnotetext{
${ }^{1}$ I am using "devotional context" in a technical sense to refer to the context of conforming oneself to ultimacy. Devotional, in this sense, does not mean expressing love and adoration to some deity. While this might be an example of a devotional context in my technical usage, my sense is much broader than this. See chapter two for more details.
} 
traditions. In chapter four, I show how this account can also illuminate the diversity of emotional religious life both across and within religious traditions. In the final chapter, I use this model to explore the role of religious emotions in the religious life, particularly the relationship among religious emotion, cognition, and practice. 


\section{TABLE OF CONTENTS}

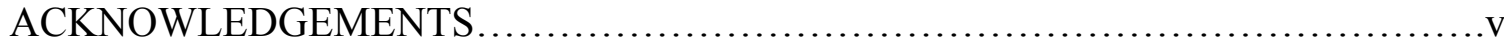

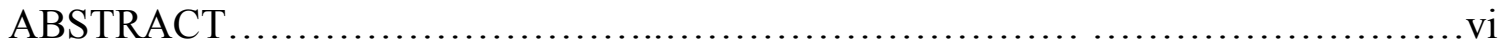

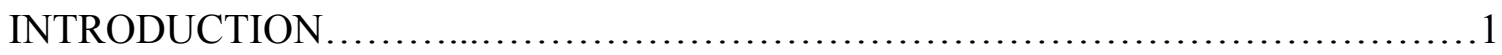

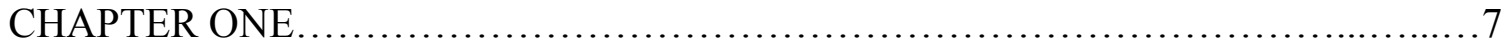

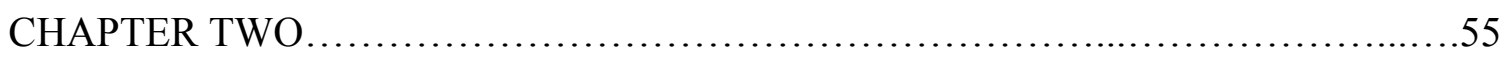

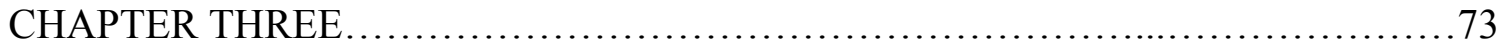

CHAPTER FOUR .......................................................... 108

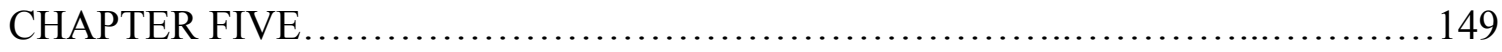

CONCLUISION ............................................................. 174

REFERENCES....................................................... 180

CURRICULUM VITAE....................................................... 191 


\section{INTRODUCTION}

The academic study of emotions is currently experiencing a multidisciplinary resurgence. Within the past decade, anthropology, experimental psychology, neuroscience, evolutionary biology, philosophy, musicology, and literary studies (just to name a few disciplines), have all made valuable contributions to our understanding of the emotions. Recently, philosophers, theologians, and religious studies scholars have begun to apply these findings to specifically religious emotions or the role of emotions in a religious context. However, the academic literature on religious emotions is still insignificant relative to the vast amount of work dedicated to religious belief and practice. This fact is peculiar given the longstanding assumption of a close and complex relationship between religion and emotion. Remembering that ancient Greek theater was a form of worship, both Plato and Aristotle observed its ability to evoke emotional responses. Additionally, the mainstream Christian interpretation of the spiritual life as a dialectic between fear and love is a notion that can be traced back to Plato's late work Pheilbus. ${ }^{2}$ More recently, romantic philosophy emphasized this emotional and intuitive aspect of religion. In his 1830 edition of The Christian Faith, Friedrich Schleiermacher famously identified the basis of religion in a feeling of absolute dependence. "The piety which forms the basis of all ecclesiastical communions is, considered purely in itself,

\footnotetext{
${ }^{2}$ Petri Järveläinen, "What are Religious Emotions?,” in Religious Emotions: Some Philosophical Explorations, ed. by Willem Lemmens and Walter Van Herck (Cambridge: Cambridge Scholars Publishing, 2008), 12.
} 
neither a Knowing nor a Doing, but a modification of Feeling ..."3 Building on Schleiermacher's work, Rudolf Otto remarks on the general failure of orthodox Christianity to attend to the important, non-rational aspect of religious experience. "Orthodox Christianity manifestly failed to recognize [the value of the non-rational element in religion], and by this failure gave to the idea of God a one-sidedly intellectualistic and rationalistic interpretation."4

However, during the middle of the twentieth century, academic work on religion and emotion was sparse for a number of reasons. First, the rise of positivism resulted in little attention paid toward the emotions generally. In terms of the social sciences, Ole Riis and Linda Woodhead write that this "led to a focus upon those aspects of religion that, like church attendance or neurological activity, can be observed and measured in a way that is dissociated from the personality and social position of the investigator. From this perspective, even belief, in so far as it can be clearly articulated and recorded, seems more solid and significant than feeling." Paul Tillich observed that philosophers and scientists accepted a distorted version of Schleiermacher's emphasis on religion as feeling in order to privatize religion and reduce its influence. "The word 'feeling' has induced many people to believe that faith is a matter of merely subjective emotions, without a content to be known and a demand to be obeyed. This interpretation of faith was readily accepted by representatives of science and ethics, because they took it as the

\footnotetext{
${ }^{3}$ Friedrich Schleiermacher, The Christian Faith, trans. H. R. Mackintosh and J. S. Stewart (Edinburg: T. \& T. Clark, 1999), 5.

${ }^{4}$ Rudolf Otto, The Idea of the Holy, trans. John W. Harvey (London: Oxford University Press, 1950), 3.

${ }^{5}$ Ole Riis and Linda Woodhead. The Sociology of Religious Emotion. (Oxford: Oxford University Press, 2011), 2.
} 
best way to get rid of interference from the side of religion in the process of scientific research and technical organization."6

In analytic philosophy, the renewed interest in emotion theory is often traced back to Robert Solomon's 1976 work The Passions. ${ }^{7}$ In what he calls "the myth of the passions," Solomon writes about misunderstandings of the emotions that have plagued Western philosophy from Plato forward. Solomon argues that Christian theologians and Western philosophers have been prone to view the emotions negatively as irrational and involuntary bodily happenings. According to this myth, the emotions present a challenge to rational thought and thus need to be subdued and controlled. He then sets this traditional view as the foil to his own interpretation of the emotions as cognitive and, to some extent, voluntary. In what has come to be known as cognitivism, Solomon argues that the emotions are not mere subjective feelings. Instead, human emotions often contain cognitive content which, for Solomon, take the form of evaluative judgments. In the wake of Solomon's work, cognitivism has become the dominant theory in the philosophy of emotion. While there are various versions of cognitivism, they all share and emphasize the recognition that emotions often possess intentionality. Emotions are directed at objects and are not merely subjective bodily feelings. ${ }^{8}$ Moreover, cognitivist theories share the view that the higher cognitive content of important human emotions is a necessary condition for the emotion itself and not simply the stimulus from which emotional reactions occur.

\footnotetext{
${ }^{6}$ Paul Tillich, The Dynamics of Faith (New York: Harper Row, 1957), 39.

${ }^{7}$ Robert Solomon, The Passions (Garden City, NY: Anchor Press, 1976).

${ }^{8}$ Important cognitivist philosophers (in some form or other) include the following: Robert Solomon, Martha Nussbaum, Robert Roberts, Ronald de Sousa, John Deigh, and Aaron Ben-Ze'ev.
} 
There are two important developments to note in analytic philosophy of emotion since the rise of cognitivism. First, recent critics, while accepting a cognitivist understanding of the emotions, have attacked Solomon's view of the history of philosophy as being too simplistic. According to these criticisms, it was the departure from traditional views, not the traditional views themselves, that led to the conception of emotions as irrational forces acting upon us against our will. For instance, Thomas Dixon argues that it was the secularization of psychology in the nineteenth century that led this view. ${ }^{9}$ Recent cognitivist philosophers of emotions have even returned to classical philosophy as a source of ongoing relevance to contemporary discussions of emotions. ${ }^{10}$ Within just the past two years, there have been three books published on Aquinas' theory of emotions and its relevance to contemporary philosophy of emotion. ${ }^{11}$ Secondly, this renewed interest in the emotions was quickly applied to other areas of philosophy, particularly ethics and aesthetics. Through the work of philosophers such as Iris Murdoch, John Casey, Charles Taylor, and Martha Nussbaum, the insight that the virtues and the emotions are necessary components to the moral life gained ascendancy in analytic philosophy. ${ }^{12}$ In aesthetics, current topics of research such as the paradox of fiction and the paradox of tragedy explore the relationship between cognitive emotions

\footnotetext{
${ }^{9}$ Thomas Dixon, From Passions To Emotions: The Creation of a Secular Psychological Category (Cambridge: Cambridge University Press, 2003), 3.

${ }^{10}$ See Martha Nussbaum, Upheavals of Thought: The Intelligence of Emotions (Cambridge: Cambridge University Press, 2001). Nussbaum draws upon Aristotelian and Stoic resources to develop her cognitivist account of emotions.

${ }^{11}$ See the following: Diana Fritz Cates, Aquinas on the Emotions: A Religious-Ethical Inquiry (Washington D.C.: Georgetown University Press, 2009). Nicholas Lombardo, The Logic of Desire: Aquinas on Emotion (Washington D.C.: Catholic University of America Press, 2011). Robert Miner, Thomas Aquinas on the Passions: A Study of Summa Theologiae, 1a2ae 22-48 (Cambridge: Cambridge University Press, 2011).

${ }^{12}$ See the following: Iris Murdoch, Existentialists and Mystics: Writings on Philosophy and Literature (London: Chatto \& Windus, 1997). John Casey, Pagan Virtue: An Essay in Ethics (Oxford: Clarendon Press, 1990). Charles Taylor, Sources of the Self: The Making of the Modern Identity (Cambridge, MA: Harvard University Press, 1989). Martha Nussbaum, Upheavals of Thought: The Intelligence of Emotions (Cambridge: Cambridge University Press, 2001).
} 
and the arts. ${ }^{13}$ Remarkably, however, little attempt has been made to apply recent developments in emotion theory to so-called religious emotions or toward central issues in the philosophy of religion. As Willem Lemmens and Walter Van Herck write, until recently there as been "almost total negligence ... of the relation between religion and emotions in contemporary philosophical theory of emotions." 14

It is in this light of the current state of philosophy of emotions that I would like to situate this current project. In broad terms, this work draws on classical resources, particular the thought of Thomas Aquinas, to build and apply a framework for thinking about religious emotions. The first two chapters are dedicated to building the theoretical framework. Chapter one outlines Aquinas's theory of emotions in a very general way and compares this account to recent versions of cognitivism. By placing Aquinas in conversation with contemporary accounts, I show that that his theory is able to capture the central insights of this mainstream philosophical. According to the Thomistic account that emerges in this chapter, emotions are psychosomatic forms of concern. In the second chapter, I begin to outline what makes an emotion a religious emotion. Drawing on Robert Neville's theory of religious symbols, I suggest that religious emotions are emotions that have religious symbols interpreted in a devotional context as their object. With this account of religious emotions in hand, the next two chapters are dedicated to illustrating and applying this framework in a phenomenological and comparative mode. In chapter three, I apply the framework to illustrate its promise in highlighting common emotional patterns across religious traditions. In chapter four, I show how this account can not only illuminate common emotional patterns, but also the

\footnotetext{
${ }^{13}$ See Mette Hjort and Sue Laver, ed., Emotion and the Arts (Oxford: Oxford University Press, 1997).

${ }^{14}$ Willem Lemmens and Walter Van Herck, ed., Religious Emotions: Some Philosophical Explorations (Cambridge: Cambridge Scholars Publishing, 2008).
} 
diversity of emotional religious life both across and within religious traditions. In the final chapter, I use this model to explore the role of religious emotions in the religious life, particularly the relationship between religious emotion, belief, and practice. 


\section{CHAPTER ONE \\ AQUINAS AND CONTEMPORARY EMOTION THEORY}

\section{Introduction}

There are several reasons why scholars interested in emotion theory might want to examine Thomas Aquinas's treatment of the passions. From a historical perspective, Aquinas's treatise is significant in that, at the time of its composition, it probably constituted the longest and most systematic discussion of the passions ever written. ${ }^{15}$ Susan James argues that this comprehensive account of the passions had tremendous influence on early modern philosophy and was widely read and discussed throughout the seventeenth century. ${ }^{16}$ Robert Miner explains that the rationalist philosophers of the early modern period were "responding to the non-mechanistic, teleological concepts of the passions articulated by Thomas Aquinas." ${ }^{\prime 17}$ According to Miner, if we are fully to understand the contemporary concept of emotion, we must see how it emerged from this long history of multiple transformations. ${ }^{18}$

Besides historical concerns, the resurgence of virtue ethics in moral philosophy has led to a renewed interest in Aquinas as a principal representative of virtue theory.

\footnotetext{
${ }^{15}$ Nicolas Lombardo, The Logic of Desire: Aquinas on Emotion (Washington D.C.: The Catholic University of America Press, 2011), 1.

${ }^{16}$ Susan James, Passion and Action: The Emotions in Seventeenth Century Philosophy (Oxford: Clarendon Press, 1997), 30.

${ }^{17}$ Robert Miner, Thomas Aquinas on the Passions: A Study of Summa Theologiae 1a2ae 22-48 (Cambridge: Cambridge University Press, 2009), 1.

${ }^{18}$ Robert Miner, Thomas Aquinas on the Passions, 4.
} 
Given the centrality of the emotions in his ethical theory, recent scholarship in moral philosophy has witnessed renewed interest in Aquinas's treatise. For instance, Eleonore Stump identifies Aquinas's emphasis on the role of the passions in virtue as what distinguishes his theory from Aristotle's. "Aquinas goes so far as to maintain that the passions - or the suitable formulated intellectual and volitional analogues to the passions — are not only the foundation of any real ethical life but also the flowering of what is best in it." ${ }^{19}$ Similarly, Diana Fritz Cates argues that for Aquinas "human emotions are matters of ethical concern and are, to a limited extent, subject to ethical formulation." ${ }^{20}$

Aquinas's account of the emotions also might be of particular interest to scholars who are sympathetic toward his theological commitments, for Aquinas's treatise is embedded in and plays an important part in his larger systematic theology. According to Nicolas Lombardo, “Aquinas's account of emotion centers on his account of desire. In turn, it is desire that gives the Summa Theologiae its exitus-reditus structure: Aquinas begins with God and then traces how creation flows from God's desire and returns to him through ours. Consequently, to follow the theme of emotion through the Summa is to follow the guiding principle around which Aquinas organized his most mature thought."21 Given the explicitly theological import of Aquinas's account, it might be of particular interest to scholars who, like Lombardo, work within the Christian tradition or to scholars of religion working in either a historical or comparative mode.

I have chosen to use Aquinas's theory of the passions as a resource for my account of religious emotions, not because of its historical influence or because of any

\footnotetext{
${ }^{19}$ Eleonore Stump, “The Non-Aristotelian Character of Aquinas's Ethics: Aquinas on the Passions," Faith and Philosophy 28 (2011): 31.

${ }^{20}$ Diana Fritz Cates, Aquinas on the Emotions: A Religious-Ethical Inquiry (Washington D.C.: Georgetown University Press, 2009), 27.

${ }^{21}$ Nicholas Lombardo, The Logic of Desire, xi. "Exitus-reditus" can be translated as 'going forth-return."
} 
theological commitments, but because I perceive his theory of the passions to be a plausible account of the emotions generally and can be particularly illuminating when applied to emotions in a religious context. To show the plausibility of his account, I will compare his theory to various versions of cognitivism, a mainstream contemporary view in analytic philosophy. I will argue that Aquinas's account, while not a cognitivist view, is able to capture the same central insights. The goal of this chapter is not to offer a full exposition or a close reading of Aquinas's "Treatise on the Passions."22 Instead, the focus is on placing Aquinas in conversation with contemporary philosophy of emotion. In so doing, a more robust and adequate account becomes available, and it is this broadly Thomistic account that I will apply to my analysis of religious emotions in later chapters. In this chapter, I will begin by offering a brief examination of the state of contemporary philosophical emotion theory, focusing on various versions of the mainstream cognitivist theory. I will then turn my attention toward Aquinas's account of the passions. Finally, I will compare these two approaches, outlining the contributions Aquinas's theory can offer contemporary philosophy of emotion.

\section{Feeling, Behavior, and Psychoanalysis}

Currently, the most widely accepted theory of emotions in analytic philosophy is cognitivism. William Lyons defines a cognitive theory of emotions as "one that makes some aspect of thought, usually a belief, central to the concept of emotion and, at least in some cognitive theories, essential to distinguishing the different emotions from one

\footnotetext{
${ }^{22}$ For an excellent example of such a project, see Robert Miner, Thomas Aquinas on the Passions: A Study of Summa Theologiae Ia2ae 22-48 (Cambridge: Cambridge University Press, 2009).
} 
another." ${ }^{23}$ Of course, cognitivism does not go uncriticized and there are many competing theories. However, there is general agreement that, as the non-cognitivist philosopher Jenefer Robison states, "the insights of the cognitive theory have to be preserved in any satisfactory theory of emotion." ${ }^{24}$ Understanding the value of cognitivism requires viewing it as a response to previous views, particularly the "feeling" theory, behaviorism, and psychoanalytic accounts. Thus, I will begin by focusing on an analysis of three early works that both challenge these previous theories and were important to the rise of contemporary cognitivism and the revival of philosophical interest in the emotions generally. ${ }^{25}$ The first two philosophers, Errol Bedford and Anthony Kenny, do not set out to give an account of emotion. Working squarely within the Wittgensteinian ordinary-language tradition, they are primarily concerned with how we come to know the meaning of specific emotion terms like 'shame,' 'anger,' and 'fear.' Given this focus, it is unclear whether they should be properly categorized as cognitivists. However, their criticism of feeling and behaviorist theories, namely that they do not allow us to make sense of emotion words, were influential in later, clearly cognitivist, theories. Working from the phenomenological tradition, Robert Solomon does offer an account of emotion on cognitivist lines. However, in this section I will focus on his criticism of psychoanalytic theories.

In Errol Bedford's 1957 article "Emotions," criticism is directed toward the two prevailing views of emotions: 1) emotions as feelings and 2) emotions as behavioral dispositions. His criticisms of both theories follow similar lines. First, both theories do

\footnotetext{
${ }^{23}$ William Lyons, Emotion (Cambridge: Cambridge University Press, 1993), 33.

24 Jenefer Robinson, Deeper Than Reason (Oxford: Clarendon Press, 2005), 3.

${ }^{25}$ See Errol Bedford, "Emotions," in The Philosophy of Mind, ed. V. C. Chappell (Englewood Cliffs, NJ: Prentice Hall, 1962), and Anthony Kenny, Action, Emotion, and Will (New York: Routledge and Kegan Pall, 1963).
} 
not account for how we can distinguish among various emotions. Second, they cannot account for the intuition that particular emotions are often open to rational assessment. Bedford specifically targets William James's theory as a typical example of the feeling theory according to which, as James's writes, “an emotion is a feeling, or at least an experience of a special type which involves feeling." 26 In his essay "What is an Emotion?" James explains that "our natural way of thinking about these standard emotions is that the mental perception of some fact excites the mental affection called the emotion, and that this later state of mind gives rise to bodily expression. My thesis on the contrary is that the bodily changes follow directly the PERCEPTION of the exciting fact, and that our feeling of the same changes as they occur IS the emotion."27 For James, an emotion is simply the feeling of bodily changes that occur as automatic responses to the perceived environment. However, identifying emotion with bodily feeling does not allow us to distinguish among different emotions. Beford observes that indignation and annoyance are different emotions even though, on introspection, the feeling element in each is indistinguishable. ${ }^{28}$ Not only is he claiming that feeling is inadequate to distinguish different emotional states, but he even goes so far as to claim that feeling is neither necessary nor sufficient for the proper use of an emotional term. For example, we often ascribe jealousy to individuals while admitting that they might not feel jealous. ${ }^{29}$ According to the Thomistic theory I will argue in favor of latter, feelings are a necessary

\footnotetext{
${ }^{26}$ Errol Bedford, "Emotions," in The Philosophy of Mind, ed. V. C. Chappell (Englewood Cliffs, NJ: Prentice Hall, 1962), 110.

${ }^{27}$ William James, "What is an Emotion?" in What is an Emotion?: Classic and Contemporary Readings, ed. Robert Solomon (New York: Oxford University Press), 67. (Emphasis James'.)

${ }^{28}$ Errol Bedford, "Emotions," 111.

${ }^{29}$ Errol Bedford, "Emotions," 112-3.
} 
condition for emotion. However, Bedford's central point is well taken: emotions are more than mere feelings.

The understanding of emotions as feelings not only fails to explain how we distinguish among various emotions, it also fails to account for why we consider particular emotions, or the lack thereof, to be (un)justified,(in)appropriate, or otherwise open to rational assessment. Such expression as "you ought to be ashamed" or "you have no reason to be afraid" would be nonsensical if emotions were nothing more than the feeling of bodily changes. Beford rhetorically asks "what reasons could be given for or against a feeling, or for or against its 'inappropriateness' to a situation? If someone were to say 'I felt a pang this afternoon,' it would be meaningless to ask whether it was a reasonable or unreasonable pang." ${ }^{30}$ Bodily feelings, such as an itch or toothache, are not open to moral or rational assessment in the way the emotions often are. The feeling theorist could of course deny that such expressions have literal meaning, but at the cost of the common understanding of such expressions.

Bedford also rejects behaviorist accounts of emotion on the same two fronts. Just as the feelings of indignation and annoyance are too similar to account for our ability to distinguish the two, we cannot distinguish between shame and embarrassment based on their nearly identical behavior responses. ${ }^{31}$ Distinguishing such emotions requires more than the knowledge of the psychological behavior involved. We need to analyze the logical and narrative structure in which the emotions occur. Shame is distinguished from embarrassment in that shame implies a moral failing, whereas embarrassment implies merely being in a socially awkward situation. The feeling and behavior of shame and

\footnotetext{
${ }^{30}$ Errol Bedford, "Emotions," 121.

${ }^{31}$ Errol Bedford, "Emotions," 116.
} 
embarrassment may be identical, but the thought content is the crucial differentiating factor.

Finally, Bedford argues that behaviorist accounts also fail to account for the fact that emotions are often open to rational assessment: "The way in which a man behaves will determine whether he is or is not angry. But if he is angry, the behavior evidence for this is not in itself relevant to the question whether his anger is justified or unjustified." 32 Reducing emotion to behavior or behavioral disposition eliminates the possibility of assessing the emotions in terms of their appropriateness. The thought content of an emotion is not only the crucial differentiating factor between two emotions, it is also the crucial element in assessing the appropriateness of an emotion. Bedford asks us to consider a case of unjustified resentment where "B does something that is to A's advantage, although A thinks that it is to his disadvantage." ${ }^{\prime 33}$ Not only is A's belief that she has been taken advantage of necessary to classify it as a case of resentment, but the rational ground of this belief is necessary to determine whether the resentment is appropriate in the given circumstances. Thus, for Bedford, the meaning of emotion terms cannot be reduced to purely somatic feelings and behaviors. Instead, reference must be made to value judgments.

In his book Action, Emotion, and Will, Anthony Kenny also critically responds to feeling theorists (particularly David Hume) and behaviorists (particularly Gilbert Ryle) for roughly the same reasons as Bedford. However, Kenny is more explicit in where these theories go wrong, and, in being more explicit, places emphasis on the concept of intentionality — a concept that becomes a hallmark of contemporary cognitivist theories

\footnotetext{
${ }^{32}$ Errol Bedford, "Emotions," 120.

${ }^{33}$ Errol Bedford, "Emotions," 120.
} 
of emotion. Highlighting the criticism that feeling and behavior are inadequate to distinguish various emotional states, Kenny makes a distinction between sensations (feelings) and emotions, arguing that only emotions have an intentional structureemotions are directed at objects whereas sensations are not. A fluttering in the stomach (a sensation) is not about anything beyond itself, whereas my fear is always a fear of something. Emotions have a property, intentionality, that both sensations and actions lack and thus emotions cannot be reduced to either sensations or behavior dispositions. The central problem with theories equating the emotions with feelings or behavior is that they fail to capture the intentionality of emotions - emotions are directed toward objects.

There are two additional yet related points to note in Kenny's understanding of emotions that will become important in later cognitivist theories. First, Kenny makes a distinction between material and formal objects. The formal object of $x$ ing is the object under that description which must apply to it if it is to be possible to $x$ it. ${ }^{34}$ For example, there are multiple potential material objects of my gratitude. I can feel gratitude towards my mechanic fixing my car at no charge, toward my professors helping me in revising my papers, or toward my wife for remaining married to me during my $\mathrm{PhD}$ program. But the formal object of gratitude is what must apply in order for it to count as gratitude. So we might say the formal object of gratitude is some perceived good which is freely given by some person who is also perceived as good in some respect. Thus, emotions are distinguished based on their formal rather than their material object, the evaluative category under which the material object is placed, rather than the particular object as such. The second important point to note is that, for Kenny, the intentionality of emotions is a necessary feature of the concept of emotion itself. It is not a mere

\footnotetext{
${ }^{34}$ Anthony Kenny, Action, Emotion and Will, 189.
} 
contingent matter of fact that one fears what one perceives as dangerous, but does not fear what one perceives as pleasant. Rather there is a necessary and logical relationship between fear and the dangerous. It is logically impossible for me to be angered at someone's action that I simply perceive as a benefit towards me. It is logically impossible for me to fear something that I know has already occurred. This observation is important for Kenny because if emotions were nothing but sensations or behavioral dispositions, there would be no logical constraints on the type of object each emotion could have. The fact that I am angered at perceived slights rather than benefits would simply be a contingent fact rather than a logical necessity. ${ }^{35}$

In his 1976 work The Passions, Robert Solomon offers his influential and controversial theory of emotions as evaluative judgments. ${ }^{36}$ I will have more to say about this theory in the next section of this chapter, but here I want to focus on Solomon's criticism of the alternative views. Since we have seen the general line of attack against feeling and behaviorist theories, I will limit myself to his criticisms of psychoanalytic theories of emotions. Solomon primarily targets Freud in this criticism, although he admits that Freud's theory is too complex to sum up easily. However, he identifies three major conceptions of the emotions in Freud, all of which are based on a hydraulic model where pressures from the unconscious build up and attempt to discharge by entering consciousness. ${ }^{37}$ Freud sometimes conceives emotions as these unconscious forces themselves; other times he thinks of the emotions as the forces when they erupt and are directed toward some particular person or event; and still other times, Freud

\footnotetext{
${ }^{35}$ Anthony Kenny, Action, Emotion and Will, 191-2.

${ }^{36}$ Robert Solomon, The Passions (Garden City, NY: Anchor Press, 1976), 144.

${ }^{37}$ Robert Solomon, The Passions, 145.
} 
conceives these emotions as the feeling of these erupting forces, a mere

epiphenomenon. ${ }^{38}$

Solomon claims that the net result of this hydraulic model is the minimization of the importance of consciousness in behavior. If the emotions are unconscious forces building pressure until they discharge in behavior, then there is little room for conscious agency and moral responsibility in human behavior and human emotions. ${ }^{39}$ Working within the existentialist tradition, Solomon argues that the acceptance of the psychoanalytic model is an instance of bad faith. "But whatever its popularity, [the hydraulic metaphor] . . . emerges as a hollow technical pretense which again attempts to reduce our emotions to something less than wholly human and distinctly beyond the range of our own responsibility. ... Every time one adopts such a viewpoint, ... he or she is guilty of precisely this self-serving and irresponsible self-deception." ${ }^{40}$ The central defect of the psychoanalytic theory, according to Solomon, is the passivity it assumes. It assumes the emotions are something not truly our own for which we are morally responsible.

Dissatisfaction with the views that the emotions are feelings, behavior dispositions, or non-rational forces erupting from the subconscious led to a recognition that an adequate understanding of the emotions needs to capture the intentionality of emotions and thereby the ability to explain how we distinguish subtle differences among various emotions. Additionally, a theory of emotions must explain the fact that emotions are often open to rational and moral assessment. In what would become the mainstream

\footnotetext{
${ }^{38}$ Robert Solomon, The Passions, 144-5.

${ }^{39}$ Robert Solomon, The Passions, 145-6.

${ }^{40}$ Robert Solomon, The Passions, 149.
} 
philosophical position, cognitivism attempts to capture these features by equating the emotions with forms of cognition.

\section{Cognitivism and Contemporary Emotion Theory}

The idea that thoughts are central to or involved in the emotions or the passions is nothing new. William Lyons writes that "Aristotle's account is a cognitive account, not because he believed that emotions affected our judgment, but because he also believed that judgments or cognitions were central to emotions." ${ }^{\prime 1}$ In her Upheavals of Thought, Martha Nussbaum traces the idea that emotions are appraisals or value judgments back to the Stoics. ${ }^{42}$ Even Plato argues that hope and fear involve assertions, and thus can be evaluated in terms of truth and falsity. ${ }^{43}$ However, contemporary cognitivism, which will be the focus in this chapter, arose in response to the theories criticized above and as a result of change in philosophical methodology. ${ }^{44}$ There are many different versions of cognitivism distinguished by the form of cognition they take to be central to the concept of emotion and by whether the theory takes any other elements, such as feeling or desire, to be necessary to the concept of emotion. The first classificatory division I wish to make is between "strong cognitivism" and "weak cognitivism." Strong cognitivism claims that cognition in the form of judgment or belief is a necessary condition of the concept of emotion. Weak cognitivism, on the other hand, takes a broader view of cognition to potentially include both perceptual and conceptual cognition. The second division is

\footnotetext{
${ }^{41}$ William Lyons, Emotions (Cambridge: Cambridge University Press, 1980), 33.

${ }^{42}$ Martha Nussbaum, Upheavals of Thought: The Intelligence of Emotions (Cambridge: Cambridge University Press, 2001), 3-4.

43 Plato, Philebus 40a-c.

${ }^{44}$ John Deigh shows how contemporary cognitivism was a result of a change in methodology from introspection to linguistic analysis. John Deigh, "Cognitivism in the Theory of Emotions," Ethics 104 (1994): 83-84.
} 
between what I will call conservative and liberal cognitivism. Conservative cognitivism identifies emotions with cognitions, whereas liberal cognitivism introduces further elements (feelings, desires, etc.) into the analysis of emotion. This makes for four possible categories: strong/conservative cognitivism, strong/liberal cognitivism, weak/conservative cognitivism, and weak/liberal cognitivism. While not all specific cognitivist theories would fit neatly into one of the four categories, this classification will be useful in evaluating the strength and weaknesses of various versions of cognitivism and to show what an analysis of Aquinas's theory can contribute. In this section I will argue that the weak/liberal version of cognitivism is the most plausible. To show this, I will begin by comparing representative examples of the two versions of strong cognitivism and argue that the liberal version is more plausible. Secondly, I will compare this strong-liberal version of cognitivism with a weak-liberal version and argue that the weak version is superior. This method will allow the strengths and weaknesses of cognitivism to become clear and prepare the ground for placing Aquinas's theory in conversation with contemporary views.

In his 1976 work The Passions, Robert Solomon offers what he calls "a subjective theory of the passions." Solomon grounds this theory of emotions in the phenomenological concept of intentionality ${ }^{45}$ All emotions are about something and that which they are about is called its intentional object. Whereas Kenny's central distinction is between material (the particular) object and the formal (the classificatory) object, Solomon's central distinction is between the material object (the object as it exists in objective reality) and the intentional object (the object as it is experienced, interpreted

\footnotetext{
${ }^{45}$ As we saw, the concept of intentionality is also central to Kenny's account. However, Kenny borrows the concept from medieval philosophy rather than from the phenomenological tradition.
} 
and evaluated). This distinction becomes necessary upon the realization that, in many instances, the "object" of our emotion is a nonexistent object. I may fear the government spies who have infiltrated my classroom disguised as students, even if there are no such government spies. If no distinction between material and intentional object is made, then it is difficult to analyze such situations in a satisfying manner. We would be forced to suggest that either 1) such emotions have no object (since there are no government spies in my classroom), 2) that the object of the emotion is simply "in my head", or 3) that I do not know what I am afraid of (I think I am afraid of government spies, when in actuality I am afraid of innocent students). But no option is satisfactory because I am afraid of government spies which are not simply in my head. It should be noted that this is decidedly not a Cartesian distinction between mental representation and physical object; in fact, it is a rejection of such a distinction. He writes: "This is not to defend an absurd 'two-worlds' view, a 'private' world within which we enact our emotional dramas and a public world of 'the facts.' There are rather two standpoints, one detached and one personally involved." ${ }^{46}$ It is from the standpoint of personal involvement that the emotions have their place. But this does not make emotions merely subjective. Even the most delusional emotions, Solomon writes, "virtually always have some basis in Reality (the most extreme paranoid does not make up the objects of his fear), and no object of an emotion is simply what it is 'in Reality.",47 Thus, the objects of emotions are in his view always intentional rather than material objects.

In order to account for this intentionality, Solomon argues that the emotions are self-involved, evaluative judgments. "What is an emotion? An emotion is a judgment (or

\footnotetext{
${ }^{46}$ Robert Solomon, The Passions, 176.

${ }^{47}$ Robert Solomon, The Passions, 177.
} 
a set of judgments), something we do. An emotion is a (set of) judgment(s) which constitute our world, our [subjectivity], and its 'intentional objects.' An emotion is a basic judgment about our Selves and our place in our world, the projection of values and ideals, structures and mythologies, according to which we live and through which we experience our lives. ${ }^{\text {"48 }}$ Solomon makes clear that on his analysis, the emotions are not somatic responses to cognition; rather they are forms of cognition. My fear is my judgment that I am in a dangerous situation. My grief is my judgment that I have suffered a severe loss. ${ }^{49}$

Solomon rejects identifying the emotions with feelings on the same grounds articulated by Bedford and Kenny, and he is explicit that not only is feeling insufficient, it is also not necessary. One can have an emotion without any detectable sensation or feeling, and one can have the sensations that often accompany emotions (fluttering in the stomach, etc.) without having an emotion. ${ }^{50}$ Similarly against the behaviorist, behavior is neither necessary nor sufficient according to Solomon, for we can pretend to have an emotion we do not have and some emotions are never manifested in behavior. ${ }^{51}$ Nor is desire necessary for emotions, although on this point Solomon is less than clear. He claims that emotions and desires are two species of passions. ${ }^{52}$ However, he also claims that emotions are "filled with desires which sometimes become intentions and commitments. ${ }^{, 53}$ It seems that, for Solomon, the emotions are more fundamental than desires for he claims that while natural desires such as thirst and hunger are not based on

\footnotetext{
${ }^{48}$ Robert Solomon, The Passions, 187-8.

49 Robert Solomon, The Passions, 187.

${ }^{50}$ Robert Solomon, The Passions, 161.

${ }^{51}$ Robert Solomon, The Passions, 166.

52 Robert Solomon, The Passions, 132.

53 Robert Solomon, The Passions, 280.
} 
emotions, the desires which are not pure biological needs (desire for happiness, friendship, success) "are built upon the structure provided by our emotions." "54 These desires emerge from our self-involved evaluative judgments - the emotions. Thus, for Solomon, the emotions are identified with self-involved, evaluative judgments.

We can now begin to compare Solomon's position to another strong cognitivist position, but of the liberal variety. In his 1980 book Emotion, William Lyons offers a "causal-evaluative theory of emotion." ${ }^{, 55}$ According to Lyons, emotions paradigmatically include the subject's beliefs about the situation he/she is in and an evaluation of that situation in relations to him/herself. However, an emotion is more than an evaluative judgment according to Lyons. At least certain emotions also necessarily include the wants or desires that are caused by the evaluative judgment and lead to behavior. Finally, the evaluative judgments and the desire cause somatic changes, which results in feeling. ${ }^{56}$ The crucial differentiating factor between Lyons' and Solomon's theory is the "causal" aspect of the causal-evaluative theory, which refers not to the fact that emotions in general cause abnormal physiological changes and feelings. As Lyons states, "for X to be an emotional state, $\mathrm{X}$ must include an evaluation which causes abnormal physiological changes. Both the evaluation and the physiological changes are necessary conditions for $\mathrm{X}$ being an emotional state, but neither are separately sufficient. Jointly they are."57 Adding physiological changes and their accompanied feeling as a condition for emotion is an improvement to Solomon's theory. In his attempt to distinguish emotional evaluative judgments from other disinterested evaluative judgments, Solomon writes that

\footnotetext{
${ }^{54}$ Robert Solomon, The Passions, 134.

${ }^{55}$ William Lyons, Emotion (Cambridge: Cambridge University Press, 1980) 53.

${ }^{56}$ William Lyons, Emotion, 57.

${ }^{57}$ William Lyons, Emotion, 58.
} 
'the key to the difference is the adverbs, 'disinterestedly,' 'causally,' and 'calmly.'

Emotions are self-involved and relatively intense evaluative judgments."58 But what can account for this intensity if not either feeling or desire? Perhaps Solomon could reply that the intensity lies in the strength of the conviction of the evaluative judgment. Perhaps my fear becomes less intense as I become less convicted that my students are government spies. But this doesn't explain why two people might have varying levels of intensity with very similar evaluative judgments. Two siblings may have two very different levels of intensity to their grief of a passing parent, even though the evaluative judgment is similar in both cases. This difference in intensity could occur even if both siblings were equally convinced that the parent had in fact died and both placed a similar value on this event. In short, emotions are psychosomatic, and Solomon's theory, in the attempt to refute the "feeling theory," places too little emphasis on the somatic aspects of emotions. If feelings were as peripheral to emotions as Solomon suggests, then the feeling I have when I am angry would be scarcely more related to my anger than the feeling of cottonmouth I might happen to have at the same time. ${ }^{59}$

One final important difference between Solomon's and Lyon's theory is their understanding of intentionality and the distinction between a material and an intentional object. While Lyons makes important clarifications between formal and particular objects, Solomon's understanding of intentionality and intentional object is to be preferred. Lyon's distinction between formal and particular objects is identical to

\footnotetext{
${ }^{58}$ Robert Solomon, The Passions, 188.

${ }^{59}$ In later works, Solomon admits this failure of giving proper weight to feeling in his theory: "I used to think that [evaluative judgment] was all that was essential to emotional experience, and again, I treated feelings of arousal and the like as experiential marginalia.... I am now coming to appreciate that accounting for bodily feelings ... in emotion is not a secondary concern ...." However, he never offers an account of what the place for bodily feeling is. Robert Solomon, "Emotions, Thoughts, and Feelings: Emotions as Engagements with the World," in Thinking About Feeling, ed. Robert Solomon (Oxford: Oxford University Press, 2004), 85.
} 
Kenny's distinction between formal and material objects. The formal object is the conceptual object that is non-contingently related to it. ${ }^{60}$ For instance, the formal object of fear is the dangerous. In other words, the formal object is the evaluative category under which a particular object falls on a particular occasion. Lyons defines the particular object as "some particular item — such as a thing, a person or animal, an event, or the content of one's own beliefs or imaginings, to name a few possibilities — which is the target or focus of an actual emotional state." ${ }^{\prime 61}$

Lyons then distinguishes between material and intentional objects. This distinction is similar to Solomon's, but the way these objects relate to the emotions is importantly different in the two theories. For Lyons, as opposed to Solomon, the object of an emotion can be a material object. A particular object is also a material object when this object really exists in the world, otherwise it is an intentional object. ${ }^{62}$ So, the object of my classroom fear is a material object if and only if the students are, in fact, government spies. This is not to say that all intentional objects are illusory objects, for I may love my dead grandmother even though I fully recognize she does not exist. In this case, my grandmother is an intentional, but not an illusory object. The object of my classroom fear, on the other hand, is both intentional and illusory because they are not government spies and my fear involves the illusory belief that they are government spies. The problem with Lyons distinction is that it is a sharp one and it fails to allow for degrees of subjectivity. Examining an example similar to the classroom example above, Lyons writes that the object is intentional because the object is "in some way

\footnotetext{
${ }^{60}$ William Lyons, Emotion, 101.

${ }^{61}$ William Lyons, Emotion, 104.

${ }^{62}$ William Lyons, Emotion, 107.
} 
manufactured by my mind." ${ }^{, 63}$ But all emotional cognition is in some way manufactured by the mind. There is a distinction to be made between the object as it is in reality and as someone experiences, interprets, evaluates, and relates it to him/herself. But all experience, emotional and otherwise, is as someone experiences it. Even Solomon's unemotional, detached standpoint is still a human standpoint.

There have been a number of objections raised against identifying the cognitive content of emotions with evaluative judgments. As we saw, the initial impetus toward contemporary cognitivism was the result of a dissatisfaction of feeling and behavior centered theories on the grounds that they could not explain the intentionality of emotions. However, this criticism of revival theories, while accurate, does not by itself warrant equating the cognitive content of emotions with evaluative judgments. John Deigh observes that "something can be an intentional object even if the subject has no beliefs about it and even if the subject's state of mind is such that only certain things can be its object. ... When a dog relishes a bone, the bone is the object of delight. Yet it does not follow that the dog has any beliefs about the bone."64 While equating the cognitive content of emotions with evaluative judgments does capture the intentionality of emotions, it has the unfortunate implication that animals lacking the ability to make evaluative judgments do not experience emotions. This observation has led many scholars toward a more qualified version of cognitivism that models the cognitive content of emotions on perception rather than propositional thought. A successful theory that treats the emotions as a kind of perception would still be able to account for intentionality, without limiting the phenomenon to human emotions.

\footnotetext{
${ }^{63}$ William Lyons, Emotion, 107.

64 John Deigh, "Cognitivism in the Theory of Emotions," 835.
} 
In response to such criticisms, Robert Roberts offers a "mildly 'cognitive' account" of emotions where the "basic paradigm is that emotions are a kind of perception, and perceptions in the relevant sense may, but need not, be propositional." More specifically, Roberts claims that the kinds of perception that constitute emotions is "concerned-based construals." The concept of construal escapes easy definition, but Roberts's most direct statement is that "a construal is a perceptual event or state in which one thing is grasped in terms of something else. The 'in terms of' relation can have as its terms any of the following: a sense perception, a thought, an image, a concept." ${ }^{96}$ For example, suppose a cab driver is approaching a woman who is standing on the curb when she begins to wave her arm. Seeing this as "hailing a cab," the driver slows down only to realize the woman was greeting a friend across the street. The cab driver may have made the judgment that the woman was hailing a cab, but the experience was more than the judgment. It was a perceptual experience seen in certain terms (as hailing a cab). Roberts clarifies that "construals have an immediacy reminiscent of sense perception. They are impressions, ways things appear to the subject; they are experiences and not just judgments or thoughts or beliefs. ${ }^{, 67}$

Emotions, for Roberts, are a particular type of construal, namely construals that are based on and permeated with concern: "I use 'concern' to denote desires and aversions, along with attachments and interests from which many of our desires and aversions derive. ${ }^{\prime 68}$ On this account, fear involves construing an event, person, object, etc. as aversive where the aversive "look" depends upon concern(s) of the subject.

\footnotetext{
${ }^{65}$ Robert Roberts, Emotions: An Essay in the Aid of Moral Psychology (Cambridge: Cambridge University Press, 2003), 111 and 132.

${ }^{66}$ Robert Roberts, Emotions, 76.

${ }^{67}$ Robert Roberts, Emotions, 75.

${ }^{68}$ Robert Roberts, Emotions, 142.
} 
Remorse is a construal of some particular action or omission as a culpable violation of standards that the subject is concerned (i.e. desires) to honor. Sadness is a construal of some event or state of affairs as a loss of something to which one is attached. Like the strong cognitive theories discussed above, the cognitive content is the central and distinguishing element of emotional occurrence. However, for Roberts, the cognitive content is a construal rather than judgment.

Roberts offers several reasons to prefer the identification of the cognitive content of emotions as construal rather than judgment. First, there are instances in which the cognitive content of an emotion clashes with one's judgment. Roberts explain that "we might say that the emotion makes a judgment (a proposal about reality); but this 'judgment' is just the appearance or phantasia. The subject's judgment often coincides with the emotion's 'judgment,' but often it does not." ${ }^{\prime 69}$ A particular Epcot attraction offers guests the virtual reality experience of hang gliding. Acrophobics will experience fear despite their judgment that they are not actually hundreds of feet of the ground. On Roberts's analysis, this would be due to the fact that the guests construe the situation as one of hang gliding. And while there are cases where a change in judgment amounts to a change in emotion, Roberts is correct that this does not entail the emotion is the judgment. He observes: "It may be, instead, that the change of judgment tends to carry with it a changed view of things. ${ }^{, 70}$ Secondly, it is possible to assent to all relevant evaluative judgments without having a corresponding emotion. Consider a case of faded grief. If grief centrally is the judgment that "someone has been irrevocably lost and that this person is deeply important to me," then how are we to explain the lack of grief after

\footnotetext{
${ }^{69}$ Robert Roberts, Emotions, 89.

${ }^{70}$ Robert Roberts, Emotions, 90.
} 
it fades? I still believe I irrevocably lost a friend in an auto accident ten years ago and this person is still deeply important to me, but I no longer feel grief. Of course, the liberal version of strong cognitivism could point to the fact that the judgment no longer causes abnormal bodily changes that result in feeling. Also, it might at first glance seem that this objection could apply to Roberts's own theory, for the construal of the situation in the grief and post-grief periods remains constant. However, Roberts claims the element of concern is both the reason why the grief fades and what protects him from this criticism. After the grief has faded, the element of concern no longer permeates the construal. On the other hand, Roberts notes that evaluative judgments can be made without concern for what is evaluatively judged. ${ }^{71}$ Similarly, Roberts points out that it is difficult to explain forgiveness on the evaluative judgment model. In forgiveness, the judgment that one has negatively offended you remains, but the anger does not. Roberts notes that it is "one of the many advantages of the view that emotions are appearances and not judgments that it explains phenomena like forgiveness. ${ }^{, 72}$

Finally, we have control over our emotions in a way that we do not with our judgments. For instance, I can mitigate my fear by the way in which I construe the situation, even while the judgment regarding the dangerousness of the situation stays constant. It is much more difficult to change or abandon one's judgments. ${ }^{73}$ Thus, the weak version of cognitivism that identifies the emotions as a kind of perception avoids the standard criticisms of the strong cognitivist theory while still being able to capture the intentionality of emotions and the subtlety of our emotional lives in a way the feeling and

\footnotetext{
${ }^{71}$ Robert Roberts, Emotions, 101.

${ }^{72}$ Robert Roberts, Emotions, 101.

${ }^{73}$ Robert Roberts, Emotions, 103.
} 
behaviorist theories could not. As we shall see, it is also the version of cognitivism that is closest to Aquinas's theory.

\section{Aquinas's Account of the Passions}

Reconstructing Aquinas's account of the emotions presents a number of difficulties. First, Aquinas's understanding of what he calls "the passions" is couched in a rather complex philosophical psychology. It is impossible to come to even a cursory understanding of Aquinas's thought on the human passions without at least discussing his understanding of apprehension (in both its sensitive and intellective forms), his understanding of the appetite (also in both its sensitive and intellective forms), the relationship between apprehension and the appetite, and the relationship between sensitive and intellective apprehension. Moreover, this philosophical psychology has a long and distinguished history of critical engagement. All I can do here is to present a very basic account of Aquinas's theory of the passions and those elements of his psychology which are absolutely necessary for such a basic reconstruction of his theory.

However, even if I am successful in this regard, a further difficulty arises in comparing Aquinas's thought with contemporary theories of emotions because the concept of emotion is a modern one that Aquinas does not employ. As Nicolas Lombardo notes, “The central difficulty in reconstructing Aquinas's account of emotion is that Aquinas never wrote about emotion. He wrote about appetites, passions, affections, habitus, virtues, vices, grace, and many other subjects that relate to the contemporary category of emotion, but the word 'emotion' has no direct parallel in the Latin vocabulary 
of the thirteenth century." ${ }^{, 74}$ There are two central Thomistic concepts that might correspond to the modern concept of emotion: passions and affections. Lombardo notes that Aquinas scholars unanimously interpret affection as a broad category that includes both the passions, which are movements of the sensitive appetite, and movements of the will or intellective appetite. ${ }^{75}$ So, affection refers to a broad category that includes the passions, but also includes the non-passional affections of the intellective appetite. There is also general scholarly agreement that particular psychological states that Aquinas refers to as passions (love, hope, despair, fear, anger, etc.) refer to particular states that correspond to particular emotional states. The central debate concerns whether particular non-passional affections would also correspond to particular emotional states. If so, it would be appropriate to compare Aquinas's account of the affections in general with modern accounts of emotion. If not, restricting the comparison to the passions would be more appropriate.

Diana Fritz Cates agrees with Lombardo that the term 'affectus' denotes a broad category that includes movements of both the sense and intellective appetites. Nonpassional affections are simple movements of the will that do not involve a commotion of the soul. Moreover, she assumes that the narrow category of passions is coextensive with the modern category of emotion. "I am interested," she acknowledges, "in emotions, rather than affections. I analyze as emotions what Aquinas calls passions (passiones), which are mediated by the body and do involve a 'commotion of the soul.","76 According to Lombardo, this is a mistake because he does not accept the assumption that emotions necessarily involve physiological change. This assumption, which Lombardo rejects,

\footnotetext{
${ }^{74}$ Nicolas Lombardo, The Logic of Desire, 15.

${ }^{75}$ Nicolas Lombardo, The Logic of Desire, 76n.

${ }^{76}$ Diana Fritz Cates, Aquinas on the Emotions, 8.
} 
makes it seem as if there is a correspondence between the concept of emotion and the concept of passion because Aquinas is clear that passions, by definition, involve the body and physiological change, whereas non-passional affections do not. But if we do not make the assumption that emotions involve physiological change and its feeling accompaniment, this leads to Lombardo's view that there is a "conceptual correspondence between emotion and [Aquinas's] category of affections.",77

As the above debate indicates, the problem lies less with Aquinas's distinction between passions and affections and more with our rather blunt and ambiguous concept of emotion. Questions that would need to be asked to resolve this debate are about the concept of emotion, not the concepts of passions or affections. For instance, can one feel emotions toward universal concepts of the intellect (i.e., can one feel angry at injustice in general as opposed to some particular act of injustice)? Do the emotions necessarily involve bodily feeling? Do the emotions necessarily involve physical change? I will primarily focus on Aquinas's theory of passions as emotions, although I am unable to give an essentialist definition of emotion that would fully justify this. ${ }^{78}$ Instead, I think a more fruitful way of approaching the concept of emotion is to elucidate paradigmatic, but non-essential, characteristics of emotions. ${ }^{79}$ For instance, the emotions are paradigmatically felt, are typically accompanied with bodily changes, and are usually directed toward particular objects or events. Additionally, part of my claim in chapter three will be that Aquinas's account of the passions in particular can help illuminate the

\footnotetext{
${ }^{77}$ Nicolas Lombardo, Logic of Desire, 18.

${ }^{78}$ The concept of emotion has proven notoriously difficult to define by way of a philosophical analysis of necessary and sufficient conditions. This has led many contemporary philosophers to offer paradigmatic accounts of emotions rather than essentialist definitions.

${ }^{79}$ Robert Roberts takes this approach in his Emotions: An Essay in the Aid of Moral Psychology (Cambridge: Cambridge University Press, 2003), 60-65. Here he outlines a dozen paradigmatic 'facts' that a theory of emotions needs to explain.
} 
nature of religious experience. It can serve as a reminder to the phenomenologist of religion that religious experience is often first and foremost an experience of a material context rather than a rarefied mystical experience. For all of these reasons, my focus will be on the category of the passions.

Aquinas's most extended treatment of the passions appears in the Summa Theologiae I-II 22-48. However, Aquinas never offers a comprehensive definition of passion. ${ }^{80}$ Perhaps the closest he comes to such a definition is in his approving quote of John Damascene: "Passion is a movement of the sensitive appetite when we imagine good or evil.. ${ }^{81}$ However, this definition does not fully capture Aquinas’s view, for it does not make explicit the somatic aspect of the passions which Aquinas holds to be a necessary component. He explains: "Passion ... is not found in the soul, except accidentally: but the composite [of body and soul], which is corruptible ...."82 For Aquinas, the passions do not belong properly to the mind or to the body, but to the living, embodied (human) animal as a whole. ${ }^{83}$ This view has contemporary advocates as well. For instance, Peter Goldie, reacting against what he perceives as an overintellectualization of emotions in cognitivism, writes that "our entire mind and body is engaged in the emotional experience, and all the feelings are 'united in consciousness' in

\footnotetext{
${ }^{80}$ Robert Miner notes that this lack of a concise and complete definition of the passions accords with Aquinas's usual dialectical method. Aquinas "does not desire that his writings should spare his readers the trouble of thinking. Rather than provide a complete definition of passion at the beginning, Aquinas employs a more subtle strategy. He desires that the reader should sift through the proposals of a range of auctoritates ... so that she might arrive at a conception that includes elements of the integral tradition." Robert Miner, Thomas Aquinas on the Passions, 31.

${ }^{81}$ Thomas Aquinas, Summa Theologiae I-II, q. 22, a. 3, trans. Fathers of the English Dominican Province (New York: Benzinger Bros., 1948).

${ }^{82}$ Thomas Aquinas, Summa Theologiae I-II, q. 22, a. 1, trans. Fathers of the English Dominican Province (New York: Benzinger Bros., 1948).

${ }^{83}$ Diana Fritz Cates observes that Aquinas's refusal to reduce the passions to either cognition or bodily changes "will likely appeal to readers who are unsatisfied with intellectualist accounts that neglect the body, on the one hand, and reductionist scientific materialist accounts, on the other." Diana Fritz Cates, Aquinas on the Emotions: A Religious-Ethical Inquiry, 10-11.
} 
being directed toward its object: united 'body and soul,' 'heart and mind."'84 Aquinas's emphasis on the emotions belonging to the composite leads Nicolas Lombardo to reconstruct Aquinas's basic position as follows: “A passion is a physiological and psychological response to the apprehension of a sensible good or a sensible evil, that is, an object that is known through the senses, and judged to be good or evil." 85 This is a fair working definition of Aquinas's understanding of the passions, although, as we shall see, it requires some qualification. To flesh this out, I want to begin by discussing the concept of the appetite in general and the sensitive appetite specifically. Given the appetite's close interaction with apprehension, I will then discuss Aquinas's understanding of sensitive apprehension and the relationship between sensitive and intellective apprehension. This will put us in a position to compare Aquinas's theory with the versions of contemporary cognitivism discussed above.

Eleonore Stump observes that "it is not easy to provide a satisfactory translation of 'appetitus,' especially in a single word: 'desire,' 'tendency,' 'inclination,' 'attraction,' are all more or less unsatisfactory possibilities." ${ }^{, 86}$ The reason for such difficulty is the fact that the appetite can take so many different forms based upon the nature of the objects toward which the appetite responds and the type of knowledge necessary for the appetite to respond to the object. One temptation I want to avoid at the outset is thinking of the appetite as most basically forms of hunger, thirst, and sex drive. Taking this as our model will distort Aquinas's understanding of the passions. The various forms of appetitive motion are too subtle and complex to be modeled in this way. Cates observes

\footnotetext{
${ }^{84}$ Peter Goldie, The Emotions: A Philosophical Exploration (Oxford: Clarendon Press, 2000), 55.

${ }^{85}$ Nicolas Lombardo, The Logic of Desire: Aquinas on Emotion (Washington D.C.: The Catholic University of America Press, 2011), 20.

${ }^{86}$ Eleonore Stump, Aquinas (London and New York: Routledge, 2003), 496n40.
} 
that the forms of appetitive motion include "being-attracted-to, tending-away-from, rising-up-against, being-crushed-by, being-at-rest-in, being-ill-at-ease-with, and the like. Unfortunately, when many people who study the emotions hear the term 'appetite,' they think 'hunger' or 'sex', and at that point they stop thinking clearly and creatively about the relationship between appetite and emotion." 87

Perhaps we can get a clearer picture of Aquinas's concept of the appetite by marking his distinction between three broad types of appetite. Aquinas writes that:

all things in their own way are inclined by appetite towards good, but in different ways. Some are inclined to good by their natural inclination, without knowledge, as plants and inanimate bodies. Such an inclination towards good is called 'a natural appetite.' Others, again, are inclined towards good, but with some knowledge; not that they know the aspect of goodness, but that they apprehend some particular good; as in the sense, which knows the sweet, the white, and so on. The inclination which follows this apprehension is called 'a sensitive appetite.' Other things, again, have an inclination towards good, but with a knowledge whereby they perceive the aspect of goodness; this belongs to the intellect. $^{88}$

Here Aquinas distinguishes the various types of appetites based on the type of apprehension/cognition, or lack thereof, involved in the inclination. By identifying the passions as movements of the sensitive appetite, Aquinas suggests that passions are inclinations towards or away from some sensory cognition of concrete particular objects perceived as good or bad in some respect. Thus, in order to fully understand various forms of appetitive motion, we must understand the nature of apprehension, particularly the distinction and relationship between sensory and intellective apprehension.

For Aquinas, sensory apprehension is broader than simply perceiving particulars through the senses. Aquinas notes that in higher animals, a particular object needs to be

\footnotetext{
${ }^{87}$ Diana Fritz Cates, Aquinas on the Emotions, 10.

${ }^{88}$ Thomas Aquinas, Summa Theologiae I, q. 59, a.1, trans. Fathers of the English Dominican Province (New York: Benzinger Bros., 1948).
} 
apprehended not only at the time of its sensation, but also when it is absent. Otherwise, the appetite would never be moved to seek something absent. As Aquinas states it: "Therefore an animal through the sensitive soul must not only receive the species of sensible things, when it is actually affected by them, but also must retain and preserve them." $" 89$ Thus, objects of memory and imagination are also objects of sensory apprehension.

Additionally, it is necessary for the sensitive apprehension to apprehend properties of both present and imagined objects that are not immediately available to the five external senses. Aquinas writes: "But the animal needs to seek or to avoid certain things, not only because they are pleasing or otherwise to the senses, but also on account of other advantages and uses, or disadvantages." 90 The sheep must in some way be able to apprehend the wolf as dangerous, for it does not flee the wolf based on its sensible properties. Likewise the bird must perceive the straw as useful for nest building. Aquinas recognizes that nonhuman animals "perceive these intentions only by some natural instinct," but claims that humans perceive them by means of a "coalition of ideas." 91 Unfortunately, Aquinas only minimally elaborates on what he means by a "coalition of ideas," but he labels this power the cogitative power or the particular reason, "for it compares individual intentions, just as intellectual reason compares universal intentions."92 The important point here is that the sensory apprehension does not include only sense perception of some particular object. Nor is it confined to sense perception,

\footnotetext{
89 Thomas Aquinas, Summa Theologiae I, q. 78, a.4, trans. Fathers of the English Dominican Province (New York: Benzinger Bros., 1948).

90 Thomas Aquinas, Summa Theologiae I, q. 78, a.4, trans. Fathers of the English Dominican Province (New York: Benzinger Bros., 1948).

91 Thomas Aquinas, Summa Theologiae I, q. 78, a.4, trans. Fathers of the English Dominican Province (New York: Benzinger Bros., 1948).

92 Thomas Aquinas, Summa Theologiae I, q. 78, a.4, trans. Fathers of the English Dominican Province (New York: Benzinger Bros., 1948).
} 
memories, and imaginings. The objects of sense apprehension can include all such objects combined with an evaluation of their relevance to the subject's concerns and interests. Aquinas refers to such a combination as an "intention." 93 He claims: "The apprehensive power is not drawn to a thing, as it is in itself; but knows it by reason of an 'intention' of the thing, which 'intention' it has in itself, or receives in its own way.",94

In his analysis of human nature, Aquinas distinguishes between sensory and intellective apprehension. The simplest way to make the distinction between the two is to say that sensory cognition apprehends particulars whereas intellective cognition apprehends universal concepts which are abstracted from sense perceptions. However, the fact that Aquinas makes this theoretical distinction should not imply that the two forms of cognition operate independently of one another. As Lombardo notes, "it is a structural clarification, and they should be understood as usually simultaneous and mutually interpenetrating." ${ }^{95}$ Similarly, Cates remarks that "in the final analysis, it is not the 'intellect' or the 'sense' that apprehends an object; it is the person who apprehends it." 96 Not only do we form concepts by abstracting universal features from particular sensory cognitions, but acts of the intellective apprehension can influence the way in which sensible objects appear. This last point is important for understanding how Aquinas's account can capture emotional subtlety, and thus requires some explanation. Paralleling the sensitive appetite, Aquinas's psychology also contains the intellective appetite (i.e., the will). Whereas the sensitive appetite responds to cognitions

\footnotetext{
${ }^{93}$ Nicholas Lombardo, The Logic of Desire, 21. Lombardo interprets Aquinas's concept of intention as a perception (in the broad sense to include memories and imaginings) colored by cognitive evaluation.

${ }^{94}$ Thomas Aquinas, Summa Theologiae I-II, q. 22, a.2, trans. Fathers of the English Dominican Province (New York: Benzinger Bros., 1948).

${ }^{95}$ Nicholas Lombardo, The Logic of Desire, 22.

${ }^{96}$ Diana Fritz Cates, Aquinas on the Emotions, 171.
} 
or particular objects as they are perceived as good or bad in some way, the intellective appetite responds to universal concepts of the intellect. He writes: "Now the sensitive appetite does not consider the common notion of the good, because neither do the senses apprehend the universal. ... But the will [the intellectual appetite] regards good according to the common notion of the good." 97 Aquinas writes that the will can long for wisdom ${ }^{98}$ or rejoice in justice. ${ }^{99}$ But highlighting the close and interactive relationship between the sensitive and intellective parts of the soul, he says: "And if this joy [of the will] be increased though the perfection of justice, it will overflow into the sensitive appetite, in so far as the lower powers follow the movement of the higher." Commenting on this "overflow" theory, Lombardo writes: "The will first moves the intellect by the vehemence of its affections regarding some object, so that the intellect causes the particular reason to form some intentional object that engages the passions. This intentional object then immediately prompts a response from the sense appetite."101 On Lombardo's interpretation, it is not simply that the will overflows to the sensitive appetite, but also that the intellect overflows to sensory apprehension. This seems necessary given that the sensitive appetite always responds to some intentional object. Moreover, it is not difficult to see how the intellect could change intentional objects of the sensory appetite. Suppose I find a stray dog in my neighborhood. Given that I am a dog lover, I would probably respond with joy of having made a new friend.

\footnotetext{
97 Thomas Aquinas, Summa Theologiae I, q. 82, a.5, trans. Fathers of the English Dominican Province (New York: Benzinger Bros., 1948).

98 Thomas Aquinas, Summa Theologiae I, q. 30, a.1, trans. Fathers of the English Dominican Province (New York: Benzinger Bros., 1948).

99 Thomas Aquinas, Summa Theologiae I, q. 59, a.5, trans. Fathers of the English Dominican Province (New York: Benzinger Bros., 1948).

${ }^{100}$ Thomas Aquinas, Summa Theologiae I, q. 59, a.5, trans. Fathers of the English Dominican Province (New York: Benzinger Bros., 1948).

${ }^{101}$ Nicholas Lombardo, The Logic of Desire, 90.
} 
However, if my neighbor then informs me that the dog has rabies, the intentional object would immediately change. This change would not be a result of any change in sensory input. Rather the concept of rabies would change the evaluation of the object in relation to my concerns and interests. Thus, my joy might immediately change to fear, compassion, or both. This close interaction between the sense and intellect is necessary for a charitable interpretation of Aquinas's theory and will help address criticisms highlighted later in this chapter.

Now that we have examined Aquinas's notion of the sensitive appetite in general, we can begin to explore how the various "movements" and objects of the sensitive appetite allow Aquinas to distinguish between various passions. The two principal movements of the sensitive appetite, according to Aquinas, are attraction and repulsion: "Now, in the movements of the appetitive faculty, good has, as it were, a force of attraction, while evil has a force of repulsion." 102 When an animal perceives an object as good in some way (useful, suitable, pleasing), it is attracted to the object; when it perceives an object as bad in some way (harmful, unsuitable, discordant), it is repulsed. From the two principles, Aquinas identifies six first-order passions, which I will refer to as the 'moments' of attraction and repulsion. The three moments of attraction are love, desire/longing, and joy/delight. "The first change the object produces in our appetite," he says, "is a feeling of its agreeableness: we call this love." ${ }^{103}$ Out of this feeling of agreeableness arises desire which is the striving for some sort of union (physical, communal, possessive, etc.) with the object of attraction. He continues: "So a

\footnotetext{
102 Thomas Aquinas, Summa Theologiae I-II, q. 23, a.4, trans. Fathers of the English Dominican Province (New York: Benzinger Bros., 1948).

${ }^{103}$ Thomas Aquinas, Summa Theologiae I-II, q. 26, a. 2, trans. Timothy McDermott (Notre Dame, IN: Ava Maria Press, 1991), 205.
} 
pleasurable object by attuning our appetite to itself makes us love, by attracting us to its absent self makes us desire." 104 Joy or delight results when the desired union has been achieved. The three corresponding moments of repulsion are hate, aversion, and sorrow. Hate is the orientation away from that which is perceived as bad in some way. Aversion is the striving away from the object of hate, and sorrow results when the striving away has been unsuccessful.

In addition to these six first-order passions, Aquinas also identifies five secondorder, irascible passions that result from perceived difficulties in the three-fold movement of attraction and repulsion. The two irascible passions of attraction are hope and despair. Hope occurs when the object of desire is perceived as difficult, but possible, to obtain. Despair occurs when the object of desire is perceived as so difficult as to be nearly impossible to obtain. The three irascible passions of repulsion are daring, fear, and anger. Daring occurs when the object of aversion is perceived as possible and worth trying to overcome. Fear results when the object of aversion is perceived as virtually impossible to either overcome or escape. Anger is a special case for Aquinas. It occurs when the evil is already upon the subject (where sorrow would normally be), but the object is still deemed worth trying to overcome in some way.

This is clearly meant simply as a basic formal framework. The phenomenological characteristics of two instances of the same passion might be quite different depending upon the subject or object of the passion and the circumstances in which the passion occurs. But it is the formal structure that makes a passion one of a particular type. Also, Aquinas does not limit his analysis to these eleven basic passions. He is able to analyze

\footnotetext{
${ }^{104}$ Thomas Aquinas, Summa Theologiae I-II, q. 30, a. 2, trans. Timothy McDermott (Notre Dame, IN: Ava Maria Press, 1991), 208.
} 
many other passions on this same basic framework by either specifying the object of the passion or expanding the narrative structure in which the passion occurs. For instance, Aquinas defines shame as a form of fear where the object of fear is external disgrace. ${ }^{105}$ Envy is a form of sorrow at another person's joy. ${ }^{106}$ Dismay is a sort of neutral despair where the failed attempt at attainment of the object is not perceived as harmful (as is the case with despair) ${ }^{107}$ Compassion is a mixture of sorrow and desire. It is a sorrow that results from identifying with another person who has been harmed which results in the desire to help. ${ }^{108}$ Also, Aquinas seems to suggest that one experience can be analyzed in multiple ways depending upon one's point of view. For instance, often desire or longing can be seen as a kind of sorrow because one perceives the absence of the desired object as present. ${ }^{109}$

Some contemporary scholars reject this long tradition of attempting to identify basic passions upon which more complex emotions are built. Robert Roberts argues while lists of basic emotions do highlight certain relationships between emotions, they also hide certain similarities and differences. He suggests that we will be more readily able so see the variety of ways in which various emotion types relate to one another if we avoid the temptation of creating a schema of basic emotions. ${ }^{110}$ While I agree that there are many ways to fruitfully organize various emotions in order to illuminate similarities

\footnotetext{
105 Thomas Aquinas, Summa Theologiae I-II, q. 42, a. 4, trans. Fathers of the English Dominican Province (New York: Benzinger Bros., 1948).

${ }^{106}$ Thomas Aquinas, Summa Theologiae II-II, q. 36, a. 1, trans. Fathers of the English Dominican Province (New York: Benzinger Bros., 1948).

${ }^{107}$ Thomas Aquinas, ST I-II, q. 41, a. 3, trans. Fathers of the English Dominican Province (New York: Benzinger Bros., 1948).

${ }^{108}$ Thomas Aquinas, ST II-II, q 30, a. 1, trans. Timothy McDermott (Notre Dame, IN: Ava Maria Press, 1991), 208.

${ }^{109}$ Thomas Aquinas, ST I-II, q. 36, a. 1. trans. Timothy McDermott (Notre Dame, IN: Ava Maria Press, 1991), 213.

${ }^{110}$ Robert Roberts, Emotions, 191.
} 
and dissimilarities, some organizational pattern is better than none. Roberts goes on to classify emotions based on offense, fault, defect, loss, etc., which presumably highlights certain similarities at the cost of others. So while there are certainly other ways to fruitfully organize particular emotion types, Aquinas's account is one that allows for great flexibility and the ability to capture the subtlety of our emotional lives.

\section{Comparing Aquinas's Theory and Cognitivism}

With Aquinas's basic account of the passions in place, we can begin to compare his theory to the various versions of cognitivism explored above. However, further important nuances of the theory will emerge during the process of comparison. We saw that cognitivism arose out of the difficulties of alternative views in capturing the intentionality and rationality of the emotions. I will begin by arguing that Aquinas's theory is able to capture these central insights. I will then compare Aquinas's theory with the previously considered views, showing how Aquinas is able to avoid central criticisms directed against cognitivism and how a more robust understanding of the emotions can emerge from such a comparison. I will conclude by addressing various criticisms raised against Aquinas's theory.

In the criticisms of non-cognitivist views above, we saw the importance of intentionality in explaining how various emotions are distinguished from one another. Emotions as both thoughts and perceptions capture the intentionality of emotions, for thoughts and perceptions are obviously intentional. But Aquinas, for reasons to be discussed later, clearly wants to distinguish cognition, broadly construed, and emotion. But he is nonetheless able to account for intentionality of emotions by appealing to their 
conative, rather than their cognitive, properties. The passions depend upon and respond to apprehensions of intentional objects, giving the passions themselves their intentional character. And as we saw, Aquinas distinguishes particular emotions based on the formal object they are conatively directed toward or away from.

The second charge against the feeling and behavioralist theories was that they cannot account for how the emotions can be proper objects of rational assessment. If the emotions are nothing more than bodily feeling, it would be nonsensical to speak of them as rational or irrational, appropriate or inappropriate. Of course, strong cognitivism is well-poised to explain this feature, since propositional thought, the essential element in emotions on this theory, can be rational or irrational. The problem with this response is that not all emotions are open to rational assessment. As John Deigh points out regarding animal and infant emotions, "If a creature lacks reason, it lacks the faculty whose operations are presupposed in descriptions of states of mind as rational or irrational, reasonable or unreasonable."111

Aquinas claims that there is even a certain sense in which animal passions can be said to be reasonable in a very limited sense: "[The passions] obey the reason in their own acts, because in other animals the sensitive appetite is naturally moved by the estimative power; for instance, a sheep, esteeming the wolf as an enemy, is afraid."112 Animal emotions naturally follow an instinctive judgment that aids their well-being and flourishing. But in human beings, the emotions are rational in an extended sense. He writes: "The sensitive appetite is naturally moved by this particular reason [the cogitative power]. But this same particular reason is naturally guided by the universal reason. ...

\footnotetext{
111 John Deigh, "Cognitivism in the Theory of Emotions," 847.

112 Thomas Aquinas, Summa Theologiae I, q. 81, a. 3., trans. Fathers of the English Dominican Province (New York: Benzinger Bros., 1948).
} 
Therefore it is clear that universal reason directs the sensitive appetite . . and this appetite obeys it. ... Anyone can experience this in himself: for by applying certain universal considerations, anger or fear or the like may be modified or excited."113 As one reflects and thinks about one's own situation, this reflecting and thinking shapes the way the situation intentionally appears. Cates observes that "one is more likely to apprehend a particular comment as hurtful and as a cause for anger if one believes that the person who made it is one's friend (rather than a mere acquaintance), and the friend could have known the comment would expose a painful vulnerability."114 Thus the anger is rational to the extent that the beliefs that shape the apprehension are rationally grounded. But this does not entail that the emotions are the beliefs.

The rational functions of the soul not only shape the emotions we experience, but also can direct which emotions we experience. Aquinas writes that "from the apprehension of something by the intellect there can follow a passion in the lower appetite ... in so far as that which is understood by the intellect in a universal way is represented in the imagination in particular, thus moving the lower appetite." ${ }^{\prime 15}$ In the example of the rabid dog above, my understanding of rabies directed my joy to fear through the sense perception and imagination. Thus my fear was rationally grounded to the extent that my belief that the dog had rabies was rationally grounded. Aquinas is able to deal with the challenges because of the rich interplay between the sensory and intellective apprehension. However, unlike strong cognitivism, Aquinas's theory allows

\footnotetext{
113 Thomas Aquinas, Summa Theologiae I, q. 81, a. 3, trans. Fathers of the English Dominican Province (New York: Benzinger Bros., 1948).

114 Diana Fritz Cates, Aquinas on the Emotions, 215.

115 Thomas Aquinas, Truth 26.3 ad 13, trans. James V. McGlynn (Indianapolis, IN: Hackett, 1994).
} 
human emotions to be open to rational assessment without denying that non-rational animals experience emotions.

Like the various versions of cognitivism, Aquinas is able to capture the intentionality and rationality of the emotions. However, the central difference between Aquinas's theory and cognitivism is the way these features are accounted for. Unlike cognitivist philosophers, Aquinas explicitly distinguishes cognition and emotion. However, his rationale is not so easy to determine. Question 22, article 2 asks whether passion is in the appetitive part rather than the apprehensive part. Quoting Aristotle's Metaphysics, Aquinas writes 'that 'good and evil,' i.e. the objects of the appetitive power, 'are in things themselves.' On the other hand the apprehensive power is not drawn to a thing, as it is in itself; but knows it by reason of an 'intention' of the thing. ... Hence we find it stated that 'the true and the false,' which pertain to knowledge, 'are not in things, but in the mind.' Consequently it is evident that the nature of passion is consistent with the appetitive, rather than with the apprehensive part." ${ }^{\text {116 }}$ Aquinas claims that in apprehension, we are not drawn to the object; rather we 'know' the object, truly or falsely. However, the passions somehow involve being moved by the object. As Miner states, "Apprehension brings the thing to us, as it were, through its sensible or intelligible species. Appetite, by contrast, moves us toward the thing itself." ${ }^{, 17}$ But how are we to make sense of Aquinas's notion of the passions as a movement of the sensitive appetite. Surely Aquinas's theory is not so crude as to suggest that I locomotively move every time

\footnotetext{
${ }^{116}$ Thomas Aquinas, Summa Theologiae I-II, q. 22, a. 2, trans. Fathers of the English Dominican Province (New York: Benzinger Bros., 1948).

${ }^{117}$ Thomas Miner, Thomas Aquinas on the Passions, 15.
} 
I experience fear, longing, and the like. This language is even more strange given that joy and sorrow are described in the language of rest. ${ }^{118}$

Robert Miner notes three reasons behind Aquinas's language of movement. First, while the passions are not equated with bodily and physiological change, they do involve such change. ${ }^{119}$ Aquinas would agree with Lyons that bodily change is a necessary condition of emotions, for there is an ordered and intimate connection between the body and mind. The language of motion can remind us of the bodily aspect of the passions. Secondly, the passions often do move us toward ends. Miner writes, "Aquinas privileges the category of 'motion' ... because he wants the likeness of motion to evoke the pattern of human life itself, conceived as a return to the end."120 In this sense, Aquinas observes with Roberts that the emotions involve concerns: desires, aversions, attachments, and interests. $^{121}$ But given that we can, as Roberts admits, have construals without concerns (and therefore without emotions), why should we identify emotions primarily with construals rather than with concerns? If we were to translate Aquinas's theory into the language of Roberts, we could say that the human emotions are construal-based concerns rather than concern-based construals. Or perhaps more accurately we should say emotions are concerns in response to intentions, where intentions are the objects of sense apprehension (perceptions, memories, imaginings, etc.) combined with an appraisal of their relevance to the subject's interests. By equating the emotions with cognitions, cognitivism over-intellectualizes the emotions, neglecting their somatic and conative

\footnotetext{
${ }^{118}$ See, for example, Thomas Aquinas, Summa Theologiae I-II, q. 25, a. 1, trans. Fathers of the English Dominican Province (New York: Benzinger Bros., 1948) where he says that in joy and sadness we find "something belonging to repose."

119 Robert Miner, Thomas Aquinas on the Passions, 44.

${ }^{120}$ Robert Miner, Thomas Aquinas on the Passions, 41.

121 Robert Roberts, Emotions, 142.
} 
character. A satisfactory theory of emotions needs to capture not simply intentionality, but what Maurice Merleau-Ponty referred to as motility. ${ }^{122}$ Like intentionality, motility involves being directed toward objects, but motility also makes essential reference to the body and bodily movement. The emotions are not only about objects, they also move us — to tears, to laughter, to contemplation, to action.

However, the primary reason behind Aquinas's language of movement is that Aquinas is drawing on Aristotle's definition of motion as an actualization of potentiality. In this sense, movement means something like alteration or transformation. Miner says, "A passion is an alteration that involves a change either from one contrary to another (e.g. from pleasure to sorrow), or from a privation to a quality (e.g. from being calm to being angry)." ${ }^{123}$ However, I would add to Miner's account that emotions involve not only alterations of psychological states, but are also centrally involved in alterations or transformations of character. For instance, if I have been habituated into evaluating a large range of sensory objects as dangerous resulting in many occasions of inappropriate fear, this will shape my character as a coward. A common method of transforming one's cowardly character is to deliberate illicit experiences of fear in order to be able to more accurately evaluate an object's potential affect on one's well-being. Thus, emotions not only move us toward external ends, but the cultivation of emotions move us toward internal ends of character.

Given Aquinas's emphasis on the conative character of emotion and his language of movement, I propose to reconstruct his definition of emotion as psychosomatic forms of transformational concern toward objects of sensory apprehension. While a full

\footnotetext{
${ }^{122}$ See Maurice Merleau-Ponty, "The Spatiality of One's Own Body and Motility" in Phenomenology of Perception (London: Routledge, 2002).

${ }^{123}$ Robert Miner, Thomas Aquinas on the Passions, 40.
} 
justification of this reconstruction will emerge only after I discuss Aquinas's account of particular emotions in chapters three and four, let me here offer preliminary support by discussing some of the key terms of this definition, beginning with 'concern.' I am drawing on Roberts use of the term 'concern' "to denote desires and aversion, along with the attachments and interests from which many of our desires and aversions derive." ${ }^{124} \mathrm{I}$ have chosen to replace "appetite" with "concern" in order to dislodge the common misconception that Aquinas's models the passions on basic drives like hunger, thirst and sex. ${ }^{125}$ When we examine Aquinas's treatment of particular passions in later chapters, we will see that his understanding of appetitive movement is much too subtle to be understood in this way. ${ }^{126}$

By “transformational," I am attempting to capture Aquinas's use of the language of "movement" while avoiding the misconception that this refers to locomotion. Peter King explains that "in medieval philosophical jargon, an emotion is a potency whose principle of actualization is external to its subject; in contemporary terms, an emotion is a reaction." ${ }^{127}$ Having an emotion involves a change from one state to another. That is to say, the passions are occurrent rather than dispositional. We can distinguish my disposition to fear at the sight of birds from the occurrent state of fear. Aquinas has much to say about habits and dispositions in the five questions directly following his treatment of the passions, but he distinguishes between the passions and dispositions. In addition to

\footnotetext{
124 Robert Roberts, Emotions: An Essay in Aid of Moral Psychology, 142. Again, Roberts, unlike Aquinas, identifies emotions with construals based on concerns, not the concern itself.

125 We will see below that Roberts falls prey to this misconception in his reading of Aquinas.

${ }^{126}$ I have already given some indication for why the emotions are better understood as concerns rather than construals based on concerns. However, I offer further justification for this in my discussion of Aquinas's account of love in chapter three.

${ }^{127}$ Peter King, "Aquinas on the Emotions," in The Oxford Handbook of Aquinas, ed. Brain Davies and Eleonore Stump (Oxford: Oxford University Press, 2012), 211.
} 
capturing notion that passions are reactions and occurrent, "transformational" is also intended to capture the idea that emotions motivate action and move us toward external ends. Additionally, "transformational" conveys the idea that the cultivation of emotions results in internal change of character.

Finally, the term psychosomatic is used to remind us of Aquinas's insistence of the importance of the body in emotions. For Aquinas, the emotions involve both a formal and material element. He writes that "in the passions of the soul, the formal element is the movement of the appetitive power, while the bodily transmutation is the material element. Both of these are mutually proportionate; and consequently the bodily transmutation assumes a resemblance to and the very nature of the appetitive movement."128 For Aquinas, the emotions necessarily involve bodily change and its feeling accompaniment. Moreover, there is a close connection between the two. As Peter King explains, "the physiological changes . . . are what make the associated psychological state an emotion: a desire is only a desire if its motivational force is felt in the proper way, and mutatis mutandis for the other emotions." 129

I will now conclude by addressing common criticisms raised against Aquinas's theory. Each of the three cognitivist philosophers examined above offers criticisms of Aquinas's account. In The Passions, Solomon only briefly mentions Aquinas. When he does, he lumps him in with Socrates, Plato, Aristotle, Augustine, Kant, Spinoza, and Schopenhauer as philosophers who thought the main business of philosophy to be "to

\footnotetext{
128 Thomas Aquinas, Summa Theologiae I-II, q. 44, a. 1, trans. Fathers of the English Dominican Province (New York: Benzinger Bros., 1948). I explore this issue further in the section on fear in chapter four.

${ }^{129}$ Peter King, "Aquinas on the Emotions," in The Oxford Handbook of Aquinas, ed. Brain Davies and Eleonore Stump (Oxford: Oxford University Press, 2012), 211.
} 
develop the powers of reason to enable us to control the raging forces 'from below.",130 However, the passions are not treated by Aquinas as raging forces from below. The passions are not a challenge to rational thought. First, the emotions for Aquinas are not irrational in the sense that they are always acting against reason. To the contrary, the emotions generally attract us toward that which is beneficial and away from that which is harmful. The emotions may conflict with the dictates of reason, but they need not and generally do not. In fact, it is precisely this view of the passions as resistant to reason that Aquinas argues against in question 83 article 3 of I-II of the Summa.

Williams Lyons addresses Aquinas's theory in more detail. Lyons writes that “the difficulties of [Aquinas's] theory derive from its jettisoning of the cognitiveevaluative aspects of emotion ... in favor of a pared-down causal chain from object to perception to impulse and its physiological accompaniments. Aquinas must ultimately account for the differences between, say, love and hate, in terms of impulse alone."131 Lyons operates with an example of MacGregor, who loves a particular dog, and MacKay, who hates the same dog. ${ }^{132}$ On his analysis of Aquinas's theory, the sole fact that explains the difference between the love and hate is that MacGregor is drawn toward the dog and MacKay is not. But this is not what differentiates love and hate according to Aquinas. Rather, it is the formal object. In love, the response is toward an object seen as good; in hate, the object is perceived as evil. Lyons doesn't see how this can be the case on Aquinas's account because "this would imply that there has taken some process by which it has been decided that or judged that [the object] is good [or bad]. This, we have

\footnotetext{
${ }^{130}$ Robert Solomon, The Passions, 11.

${ }^{131}$ William Lyons, Emotion, 37.

${ }^{132}$ William Lyons, Emotion, 37.
} 
seen, is not the case."133 However, there has been such a process according to Aquinas, namely sensory apprehension (which includes the cogitative power) operating in conjunction with the intellective faculties. Lyons mistakes sensory apprehension with a very simple form of sense perception, and thus fails to appreciate the nuance of Aquinas's theory.

Lyons also claims that Aquinas cannot accommodate backward-looking emotions, for there is generally no impulsion with such emotions: "Sorrow at a loss, such as the death of a best friend, does not impel a person towards or away from anything, or even to do anything at all. After all one cannot do anything. One cannot bring back the dead. Action is irrelevant, and so must be any impulse to action." ${ }^{134}$ One could respond that grief involves the desire or wish that the person was not irrevocably lost. But even this move is not totally necessary to save Aquinas's account, for as we saw the primary usage of movement (which I take Lyons to mean by impulse) is not a movement of locomotion or action, but Aristotle's definition of movement as "the actualization of what exists potentially, insofar as it exists potentially."135 By “movement," Aquinas does not primarily mean "impulse to action" (although that may be a type of movement), but actualization of potential. Thus, appetitive movement is the actualization or activation of potential concerns. Understood in this way, Lyon's criticism loses its force.

Robert Roberts attacks Aquinas's theory for relegating the emotions to the sensitive appetite. He offers four reasons for rejecting such a proposal, two of which have to do with the relationship between emotions and the body. The first of these is essentially the same line presented by Lyons: the emotions need not incline us to move

\footnotetext{
${ }^{133}$ William Lyons, Emotion, 37.

${ }^{134}$ William Lyons, Emotion, 37.

${ }^{135}$ Aristotle, Physics, 3.1.
} 
physically toward or away from the object. ${ }^{136}$ I will let my reply to Lyons on this same issue stand. A second criticism is that "it is at least questionable whether an emotionepisode must, to be a genuine emotion, generate or be accompanied by some bodily change analogous to penile arousal or salivation." ${ }^{\prime 137}$ The example used to illustrate this objection points to a larger problem with Roberts's analysis of the sensitive appetite. As mentioned previously, modeling the sensitive appetite on the sex and food drive, as Roberts does, oversimplifies Aquinas's account of the passions. But Aquinas does claim that bodily change (and its feeling accompaniment) is a necessary feature of the passions, which is the central issue of Roberts's criticism: For instance, "nostalgia seems to be an emotion with a minimal arousal dimension." ${ }^{, 138}$ In response to Roberts's criticism, one could classify such cases, with a heavy dose of exegesis, as, in Aquinas's terms "simple affections without passion or commotion of the soul." ${ }^{139}$ Roberts anticipates this move when he writes that "[Aquinas's] response to these examples is to deny they are emotions. ${ }^{140}$ However, Aquinas never denies simple affections of the intellectual appetite are emotions; he denies they are passions. Whether or not non-passional affections are instances of modern emotions is an entirely separate question. Still, I do not think cases of nostalgia could be for Aquinas non-passional affections, for he distinguishes the sensitive and intellective appetite by claiming that the sensitive appetite (passion) is a response to some apprehended particular good, whereas the intellective appetite (non-passional affection) is a response to the intellectual apprehension of the

\footnotetext{
${ }^{136}$ Robert Roberts, "Thomas Aquinas on the Morality of Emotions," History of Philosophy Quarterly 9 (1992): 291.

137 Robert Roberts, "Thomas Aquinas on the Morality of Emotions," 295.

${ }^{138}$ Robert Roberts, "Thomas Aquinas on the Morality of Emotions," 295.

139 Thomas Aquinas, Summa Theologiae I, q. 82, a. 5, trans. Fathers of the English Dominican Province (New York: Benzinger Bros., 1948). Robert Miner takes this approach in his response to Roberts's criticism. See Robert Miner, Thomas Aquinas on the Passions, 36-38.

${ }^{140}$ Robert Roberts, “Thomas Aquinas on the Morality of Emotions," 295.
} 
good in general. ${ }^{141}$ Nostalgia seems to necessarily involve the memory of some particular event or person. So, I think the better response is to grant Roberts that there may be emotions without a noticeable feeling element, ${ }^{142}$ but deny that this is a devastating critique. Feelings are at least paradigmatic of emotional occurrences such that Thomas's theory can serve as an important corrective on overly cognitivist theories in this regard.

The second two criticisms offered by Roberts concern the relationship between the emotions and the intellect. Roberts writes that "virtually all human emotions are inseparable from conceptual or rational powers in a way that most instances of the sensory appetites are not.."143 But as I argued above, understanding the seamless interaction between the intellective and sensitive functions is crucial for an adequate understanding of Aquinas's theory. Aquinas can admit that, in the human animal, the conceptual and rational powers shape our sensory apprehension and thereby shape human emotions. Roberts focuses on anger in this critique because Aquinas specifically states that the provocation to anger is always something that is regarded as unjust. ${ }^{144} \mathrm{He}$ concludes: "This suggests that to be angry ... requires a minimal mastery of some moral concepts: just, responsible, blameworthy, etc.... The implication of what I am saying is that most of the emotions that humans experience are never experienced by animals, and do not, therefore, belong to a non-rational appetite." ${ }^{, 45}$ However, Aquinas agrees, first of all, that anger is a special case: "Anger is a desire for vengeance. Now vengeance

\footnotetext{
141 Thomas Aquinas, Summa Theologiae I, q. 59, a. 1.

142 However, from introspection on my own experience, nostalgia does involve feeling.

143 Robert Roberts, "Thomas Aquinas on the Morality of Emotions," 291.

144 Thomas Aquinas, Summa Theologiae I-II, q. 47, a. 2, trans. Fathers of the English Dominican Province (New York: Benzinger Bros., 1948).

${ }^{145}$ Robert Roberts, "Thomas Aquinas on the Morality of Emotions," 291-2.
} 
implies a comparison between the punishment to be inflicted and the hurt done... Now to compare and to draw an inference is an act of reason. Therefore anger, in a fashion, requires an act of reason." ${ }^{\text {146 }}$ Aquinas's allows for something like anger in animals based on the natural instinct of the estimative powers, ${ }^{147}$ but would obviously deny that animals experience human anger or any other human emotion. There is an analogical relationship between animal and human emotions, such that animal fear, sorrow, anger are like but not identical to human fear, sorrow, and anger. Our higher cognitive abilities do change our emotional experiences, but that does not mean they are rational in a strong sense. What Aquinas primarily intends to convey by placing the human passions in the sensory appetite is that they are directed at particulars. I do not get angry at injustice in general or the concept of injustice, but at particular acts of injustice.

A final criticism by Roberts of placing the emotions in the sensory appetite is that "the objects of emotions are not always represented sensorily or in sensory-like images." ${ }^{148}$ He offers an example of Mary who is indignant at the president for always choosing the most bellicose "peace plans." In these moments of indignation, Mary is not necessarily subject to any sense impressions of the president, nor to any imaginal counterpart of such sense impressions. Such impressions may increase the likelihood or strength of the impressions, "but no such sense object is the object of the emotion in the way that another's body is an object of sexual desire, or a salmon steak is an object of gustatory desire. Even if she can see [the president's] face, it is not that she is mad at; she is mad at [the president], and furthermore she is mad at him for a reason that cannot

\footnotetext{
${ }^{146}$ Thomas Aquinas, Summa Theologiae I-II, q. 46, a. 4, trans. Fathers of the English Dominican Province (New York: Benzinger Bros., 1948).

${ }^{147}$ Thomas Aquinas, Summa Theologiae I-II, q. 46, a. 4, trans. Fathers of the English Dominican Province (New York: Benzinger Bros., 1948).

${ }^{148}$ Robert Roberts, "Thomas Aquinas on the Morality of Emotions," 293-4.
} 
be represented to the senses." ${ }^{149}$ However, like the previous criticism, this fails to notice the rich intentionality of Aquinas's notion of sensory apprehension. Aquinas never suggests that the intentional object of sensory apprehension is limited to sense data, a sensory object, or a mental image. It can also include value laden perceptions, memories, and imaginings. But it is limited to particulars, and Mary is indignant at this particular president for this particular peace plan. Nor do we have passional reactions toward general concepts. Despite the truth in Roosevelt's claim, we do not fear, in an emotional sense, fear itself.

\section{Conclusion}

I agree with Roberts that "no theory of emotion ... accommodates [all the facts about emotions] gracefully." ${ }^{150}$ However, Aquinas's account of the passions does capture paradigmatic emotional states fairly well. But more importantly, he provides significant correctives on mainstream cognitivist accounts. Aquinas's account enables us to view the emotions as intentional, but in a way that captures important symmetries between human and nonhuman emotions. He forces us to attend to the embodied aspect of emotional experience, a feature too often overlooked in the cognitivist attempt to correct feeling and behavioralist theories. Like Roberts, he brings to our attention the importance of concern in emotional experience. But unlike Roberts, he places concern at the very center of emotional experience, rather than cognitions and construals that arise out of concerns. For Aquinas, the emotions are psychosomatic forms of transformational concern which are differentiated based upon the formal nature of their intentional object.

\footnotetext{
${ }^{149}$ Robert Roberts, "Thomas Aquinas on the Morality of Emotions," 290.

${ }^{150}$ Robert Roberts, Emotions, 64.
} 
In further chapters, I will show how this conception of the emotions generally can help illuminate the nature of religious emotions specifically. On this account, what makes an emotion a religious emotion is the intentional object, in this case religious symbols. But before we can flesh this out, we must look first at the nature of religious symbols. 


\section{CHAPTER TWO}

\section{RELIGION, RELIGIOUS SYMBOLS, AND RELIGIOUS EMOTIONS}

\section{Introduction}

According to the Thomistic account of the emotions outlined in chapter one, the emotions are psychosomatic forms of transformational concern (desires, aversions, attachments, interests, etc.) toward intentional objects of sensory apprehension. Moreover, particular emotions and emotion-types are distinguished in terms of their formal object. If we are to apply this account of the emotions generally to consider what a religious emotion might be or what makes a particular emotion religious, at least some appeal will have to be made to the formal object. In this chapter, I will combine the Thomistic theory of emotions generally with Robert C. Neville's theory of religious symbols to begin to develop an account of religious emotions. According to this theory, religious emotions are psychosomatic forms of transformational concern with religious symbols interpreted in a devotional context as their formal object. The primary goal of this chapter is to clarify what I mean by "religious symbols interpreted in a devotional context" and how this understanding of the object of religious emotions can contribute to recent philosophical work on religious emotions. This will put me in a position to offer an analysis of specific religious emotions in the following two chapters. 


\section{Religion}

The project of this chapter requires me to begin by offering a brief working definition of religion. The concept of religion is, of course, notoriously vague, and there is no shortage of proposed definitions of religion or proposals that academics should abandon the category all together. I want to be clear that I am not offering an essentialist definition of religion, nor do I want to suggest my definition should be considered normative for other projects. However, it is important to offer a tentative and heuristic definition for the purposes of this project. In this context, I take religion to be a set of interrelated and traditional human practices performed in response to perceived ultimacy with the end of individual, social, and/or global transformation. ${ }^{151}$

The concept of ultimacy is perhaps more vague than religion, and it needs to be if it is going to be a category of cross-cultural comparison. One could take a denotative approach and define ultimacy as the perceived reality symbolized by concepts of God, Brahman, the Dao, Buddha Nature, etc. But this would fail to say what makes these perceived realities "ultimate." Perhaps we could better define ultimacy as that which conditions and gives meaning to all of existence or the absolute value that conditions all other values. Robert Neville suggests it is better to think of two related senses of "ultimacy." In the ontological sense, ultimacy refers to the ultimate ground or principle of being. In the anthropological sense, it refers to the ultimate goal of human existence. ${ }^{152}$ Of course, many traditions symbolize ultimacy in both of these senses and the two senses are often connected even if one sense receives greater emphasis. The

\footnotetext{
${ }^{151}$ My emphasis on the transformative/soteriological aspect of religion is indebted to John Hick's interpretation of religion. See John Hick, An Interpretation of Religion: Human Responses to the Transcendent (New Haven, Yale University Press, 2004).

152 Robert C. Neville, Realism in Religion: A Pragmatist's Perspective (Albany, State University of New York Press, 2009), 183.
} 
ultimate reality symbolized as God in the monotheistic traditions determines an ultimacy of human life which might be symbolized as communion with God. In non-theistic traditions, great emphasis might be placed on the anthropological sense. For example, as Robert Neville and Wesley Wildman note, in some forms of Buddhism "it is ultimately important to realize there is no ontological ultimate, or at least nothing ontological to refer to ultimately." ${ }^{153}$ By transformation, I am referring to the process of change from some non-ideal state of existence to an ideal state of existence. In this respect, I am highlighting the soteriological dimension of religion, whether understood as a transformation from exile to shalom, sin to righteousness, pride to submission, samsara to moksha, suffering to nirvana, chaos to harmony, etc. Finally, by practices I am referring to the means by which this transformation is thought to occur, although I will have to give a fuller account of practices in the final chapter of this project.

It is also important to briefly explain what I mean by the qualifiers "traditional" and "interrelated." By "traditional" I simply mean that the practices and the symbols used in practices are culturally embedded and acquired. I do not mean that the practices are necessarily institutionalized, although they often are. A recent Pew Research survey found that one-fifth of all adult Americans and a third of adults are "religiously unaffiliated." 154 Of these unaffiliated adults, many described themselves as "spiritual but not religious." ${ }^{255}$ My qualification of traditional is not meant to exclude those practices that do not take place in an institutionalized setting. But it is designed to suggest that

\footnotetext{
${ }^{153}$ Robert C. Neville and Wesley J. Wildman, "Introduction," in Ultimate Realities, ed. Robert C. Neville (Albany: State University of New York Press, 2001), 2.

${ }^{154}$ Luis Lugo, “'Nones' on the Rise: One-in-Five Adults Have No Religious Affiliation,” The Pew Forum on Religion and Public Life (Washington D.C.: Pew Research Center, 2012), 9.

155 Luis Lugo, “'Nones' on the Rise: One-in-Five Adults Have No Religious Affiliation,” The Pew Forum on Religion and Public Life (Washington D.C.: Pew Research Center, 2012), 9.
} 
those who practice some sort of religiously unaffiliated spirituality acquire the symbols used in practice from their surrounding community and culture, even if they do not always recognize that this is the case. For example, half of those unaffiliated adults claimed to feel a deep or spiritual connection with nature. ${ }^{156}$ This identification with nature (which may well count as a practice) involves symbols (nature, mother earth, etc.), which are culturally and communally acquired. By "interrelated" I mean that the various practices are all related to, in some way or another, some sort of transformational goal, even if that goal remains inchoate to those engaged in the practices.

\section{Neville's Theory of Religious Symbols}

The primary thesis of Neville's work on religious symbols is that religious symbols are to be understood through three related but different kinds of analyses. ${ }^{157}$ According to Neville, "the first is the study of what religious symbols refer to and how they refer. Only by distinguishing a class of religious referents is it possible to say in any more than a conventional form what makes a symbol religious." ${ }^{158}$ The second element in Neville's theory is interpretation. Drawing on Charles Peirce's semiotics, Neville claims that all interpretations involve an irreducible triadic structure. In addition to the signified and the signifier, an analysis of interpretation must take into account the interpreter. ${ }^{159}$ In addition to reference and interpretation, the third type of analysis concerns the meaning of religious symbols as defined by their place within a semiotic system. Neville explains that "the meaning-analysis involves showing how symbols are

\footnotetext{
${ }^{156}$ Luis Lugo, “'Nones' on the Rise: One-in-Five Adults Have No Religious Affiliation,” The Pew Forum on Religion and Public Life (Washington D.C.: Pew Research Center, 2012), 9-10.

${ }^{157}$ Robert C. Neville, The Truth of Broken Symbols, xviii.

${ }^{158}$ Robert C. Neville, The Truth of Broken Symbols, xviii.

${ }^{159}$ Robert C. Neville, Religion in Late Modernity, 46.
} 
embedded within symbol systems, and how symbol systems relate to one another, interdefining and overlapping."160 Given the close relationship between interpretation, reference, and meaning, it is difficult to treat each area independently, but, in what follows, I will try to do this as far as it is possible, showing how each of them can provide conditions for the concept of religious emotions.

For my purposes, it makes most sense to begin with the element of interpretation. Neville defines interpretation as "an interaction between interpreters and their world guided by the signs and semiotic systems of their culture."161 According to Neville, one of the unique and valuable aspects of Peirce's semiotics is his thesis that interpretation is a triadic relation of sign, object, and interpreter. While much modern philosophy focuses on the dyadic relation of mental image to real object, Pierce emphasized the fact that a sign relates to its object because an interpreter takes it to do so. ${ }^{162}$ Neville argues that it is particularly important to keep in mind the purposes of the interpreter when considering religious symbols. He identifies three broad interpretive contexts, each one distinguished from the others based on the purpose of the interpreter. "The theological context," writes Neville, "is shaped by concerns for intercommunicability across all contexts [and] for universality of statement." ${ }^{\prime 63}$ The primary goal in the theological context is theoretical understanding, clarity, and systemization. The product of interpretation in the theological context is generally abstract doctrine and theory. Concerning the communal context, Neville writes that "the dominant purpose . . is the shaping and direction of the life of

\footnotetext{
${ }^{160}$ Robert C. Neville, The Truth of Broken Symbols, xviii.

${ }^{161}$ Robert C. Neville, Religion in Late Modernity, 46.

${ }^{162}$ Robert Cummings Neville, "A Peircean Theory of Religious Interpretation," in Pragmatism and Religion, ed. Stuart Rosenbaum (Urbana and Chicago: University of Illinois, 2003), 290.

${ }^{163}$ Robert C. Neville, Religion in Late Modernity, 60.
} 
the community." ${ }^{\prime 164}$ In this context, religious symbols presented in songs, liturgies, art, and architecture can serve to bind the community together and shape communal identity. Finally, Neville claims that "the devotional context for religious symbols is dominated by the purposes of conforming the soul or self to the religious object in whatever respects the symbols can represent the object." ${ }^{\prime 165}$ It is important to note that Neville uses "devotional context" as a technical term, and by devotion he does not mean expressing love and adoration to some deity. He means using religious symbols to conform oneself to ultimacy, regardless of how this ultimacy is conceived. In this context, the concern is not so much about gaining a theoretical understanding of the divine or whether such symbols bind together and give shape to the community, but rather the attempt to engage such symbols in a pragmatic way in order achieve certain religious ends. Religious symbols in this context are supposed to transform the interpreters to be in better accord with what they symbolize.

Neville notes that "symbols for devotional contexts can be far more fantastical and imaginatively extreme than those in theological or social contexts. Not believing in gods in any literal sense, Tibetan Buddhists meditate on horrific images of bloody gods girdled with skulls in order to become awakened from their sleep. Christians, Daoist, and Muslims meditate on hells for similar reasons." ${ }^{.166}$ As we will see, this is not to suggest that symbols on the devotional level lack reference. However, the existential concern that permeates the devotional level shapes the way in which these symbols refer and often the very symbols utilized. Not paying enough attention to the context can result in misinterpretation and confusion. The symbols of bloody gods with skulls will not be an

\footnotetext{
${ }^{164}$ Robert C. Neville, Religion in Late Modernity, 60.

${ }^{165}$ Robert C. Neville, Religion in Late Modernity, 60.

${ }^{166}$ Robert C. Neville, Religion in Late Modernity, 60.
} 
effective symbol if one's purpose is gaining a theoretical understanding of the divine. Conversely, Neville notes that "the high abstractions at the outcome of theological investigation are likely to be so removed from symbolic powers of transformation as to be inefficacious and symbolically barren" in a devotional context. ${ }^{167}$ Given my focus on the soteriological dimension of religion, my focus will be on symbols operating in a devotional context and religious emotions, as I will explore them, have as their object symbols interpreted in this context. More will have to be said about the analysis of interpretation later on, but first we must turn our attention to reference.

The analysis of reference is important according to Neville, for what makes a sign a religious symbol is its reference to ultimacy. However, the issue of religious reference is highly problematic. Many religious traditions have a point at which they claim that ultimacy is not an object or a thing. Rather, the ultimate transcends all finite things. Neville puts the problem of reference succinctly when he asks, "If the religious object... is beyond reference to finite things, is [the religious object] beyond reference? If the answer is yes, then [the religious object] cannot be engaged, and Peirce's theory of interpretation is of no help. If the answer is no, then we have to speak to the issue of nonfinite reference." ${ }^{\prime 168}$ Neville's proposed solution to this difficulty is to suggest that religious symbols do not refer to the infinite as such. Rather they refer, directly or indirectly, to what he calls "finite/infinite contrasts." Neville defines a finite/infinite contrast as "some finite thing to which reference can be made that is taken to be a boundary line or world-founding element in the culture, community, or person bearing

\footnotetext{
${ }^{167}$ Robert C. Neville, The Truth of Broken Symbols, 151.

168 Robert Cummings Neville, “A Peircean Theory of Religious Interpretation," in Pragmatism and Religion, ed. Stuart Rosenbaum (Urbana and Chicago: University of Illinois, 2003), 290.
} 
the referring symbol."169 While it is a finite object that is primarily referred to in a religious symbol, the term 'contrast' is meant to suggest that the object is taken to be of such importance that the symbol, through negation, also points beyond the finite worldfounding element. Thus, the object of a religious symbol is neither the infinite as such nor the finite world-founding element as such, but to the finite in contrast to the infinite. As Neville proposes, the real object of a religious symbol is "the situation that would obtain if the finite thing did not exist or have its world-constructing importance. In short, the contrast has to do with the importance of the finite thing for the contingent existence of the world, in some respect, or the world of human meaningfulness."170 While this account of religious symbolic reference is obviously vague and abstract, it is purposefully so because Neville wants a theory that is open to the various ways cultures and religious traditions articulate this contrast. To clarify, Neville writes:

The obvious grand example of a finite/infinite contrast in the West is the existence of the physical cosmos: without that there would be the infinite, or nothing. In Western monotheisms, the infinite is often given a positive interpretation as creator. East Asian religions such as Daoism and Confucianism often do not identify the existence of the cosmos per se as a finite/infinite contrast but rather its internal order and processive principles such as the Dao. ... Some South Asian traditions, for instance Vedanta and Vaishnava, focus the existence and creation theme in ways analogous to [the West]. But others such as Buddhism are careful to deny the possibility of focusing referentially on the existence of the cosmos and deny anything positive in the infinite or emptiness that is the true condition of form. ${ }^{171}$

In addition to the physical cosmos as a whole, the grounds for the world of human meaningfulness can serve as the site of a finite/infinite contrast, for without such grounds

\footnotetext{
${ }^{169}$ Robert C. Neville, Religion in Late Modernity, 46.

170 Robert C. Neville, The Truth of Broken Symbols, 70.

${ }^{171}$ Robert C. Neville, Religion in Late Modernity, 46.
} 
of value and meaning (whether symbolized as God or in some other way) the physical world might exist, but a meaningful and purposeful world would not.

To clarify this concept of "finite-infinite contrast," Neville, drawing on Kant's epistemology, distinguishes it from schema and schema images. For Kant, a schema is a rule by which a non-empirical category of the understanding is associated with a mental image. Similarly, a schema of a finite-infinite contrast is a "set of symbols that schematizes the finite/infinite contrast to finite proportions."172 For example, representations of heaven or paradise schematize the finite/infinite contrast as the goal of human life to a spatial image. The divine is not really a king on a throne in a place with streets paved with gold. But imagining the infinite in this way may (depending on certain conditions of the interpreter) help structure the relationship between the interpreter and the religious end. ${ }^{173}$ Finally, schema images are specific symbols of finite/infinite contrasts. Neville explains that "a schema is a rule for generating a schema image. If heaven as a spatialized place for the infinite is a schema, the schema images might be a garden place, a throne room, a mansion, a banquet table, and so forth." 174

On Neville's analysis, there are three modes of reference: conventional, iconic, and indexical. However, it is the distinction between iconic and indexical reference that is crucial for my purposes. In iconic reference, Neville writes that "the symbol, broadly conceived, has an inner structure and the reality referred to is taken to be like that structure." 175 In iconic reference, the object is taken to be like the symbol in some respect. There are various ways in which the object may be taken to be like the symbol,

\footnotetext{
172 Robert C. Neville, Religion in Late Modernity, 48.

173 Robert C. Neville, Religion in Late Modernity, 48.

174 Robert C. Neville, Religion in Late Modernity, 48.

${ }^{175}$ Robert C. Neville, Religion in Late Modernity, 54.
} 
but it will only be so in certain respects and not in others. Neville cites myths and narratives as having iconic reference and, as such, they are taken to be disclosive of reality by the engaged interpreter. But this disclosure is not a simple isomorphic mirroring of reality. Dostoevsky's Crime and Punishment can tell us something about reality despite the fact that there is no historical personage corresponding to the character of Raskolnikov. When we read the novel, we might recognize that psychological or social reality is, in some respects, like the narrative, all the while knowing it to be a work of fiction. Religious myths and narratives work in similar fashion, except that the referent is not simply a psychological or social reality, but a finite/infinite contrast.

Neville writes that indexical reference involves "a symbol's pointing to or indicating its object, whatever else it says iconically or conventionally.""176 Peirce's paradigm example of indexicality was the way an effect refers to its cause (although not all indexical signs are taken to be caused by the object). Smoke billowing from a house is an indexical sign of fire. In such cases, the symbol points toward something other and unlike the symbol. While all forms of reference operate in all three interpretive contexts, in the devotional context, indexical reference is emphasized. Neville explains, "In general, indexically referring signs connect interpreters causally with the realities interpreted. . . For religions, indexical reference is important because it is crucial for attunement to ultimate realities."177 In a devotional context, a symbol refers indexically to ultimacy when the symbol allows the devotee to engage with ultimacy even though the devotee does not take the symbol to be iconic of ultimacy. For example, devotees might meditate on horrific images of hell in order to be aroused from complacency, which

\footnotetext{
${ }^{176}$ Robert C. Neville, The Truth of Broken Symbols, 41.

${ }^{177}$ Robert C. Neville, "A Peircean Theory of Religious Interpretation," in Pragmatism and Religion, ed. Stuart Rosenbaum (Urbana and Chicago: University of Illinois, 2003), 281.
} 
prevents the end of transformation. Thus, the image of hell points the devotee toward ultimacy, even though the devotee would certainly not think the image of hell is iconic of the divine. Of course this distinction often causes confusion because symbols which are effective when taken as indexical can mistakenly be taken as iconic. Neville explains that "a person indexically related to Jesus such that love of God and neighbor animates the person's life has a true reference, even though the person might be hopelessly naïve and prone to error when ascertaining who the historical Jesus was."178

This leads me to a final important distinction in Neville's analysis of reference: the distinction between primary and secondary referents. Neville explains that "the primary referent [of a religious symbol] is the religious object, which is best understood as a contrast joining something finite and something infinite.... The secondary referent is to the symbolizers' own culture, stage of life, and state of soul. That a finite thing can function in a finite/infinite contrast is relative to the nature of the interpreter referring to it." ${ }^{179}$ For instance, parents as religious symbols will probably not be able to refer to God for someone who has been abused by their parents. Creation ex nihilo can serve as a symbol only for those cultures that place importance on physical cosmology. Western students often find it difficult to see how the Hindu goddess Kali, who is always portrayed as a wild-eyed, frightening figure with a belt made of human limbs and wearing a garland of skulls, could possibly refer to the divine. However, it is not simply accidents of birth or culture that determine if a symbol can engage the interpreter. There is also the issue of cultivated competency. Neville analogizes that "musical connoisseurs have the competence to hear things their novices miss. Westerners, until trained, cannot

\footnotetext{
${ }^{178}$ Robert C. Neville, “A Peircean Theory of Religious Interpretation,” 281.

${ }^{179}$ Robert C. Neville, Religion in Late Modernity, 53.
} 
hear what ordinary Chinese people hear in traditional Chinese music." ${ }^{\prime 180}$ Learning to semiotically engage reality requires cultivation of potentialities, which, according to Neville, involves "learning though imitation and association what cannot be said significantly in words."

Learning through imitation highlights the third element in religious symbolism: meaning. Neville's makes a distinction between network and content meaning. He writes that "network meaning is the meaning structure defined by a semiotic code, according to which there is a range of signs to which a given sign can refer. . . Content meaning, by contrast, are those by which reality is engaged." ${ }^{\prime 182}$ Grasping network meaning involves understanding the intracode relations among symbols. An analysis of network meaning consists in making explicit these intracode relationships between various symbols, not the relationship between symbols and reality. Neville writes that network meaning "is not an intentional study of actual interpretations, in which real objects are engaged, but only of possible interpretations as these are made possible by semiotic structures. The symbols in their extensional structure are referred to other signs of objects, not to real objects themselves."183 To take a religious example, I might begin an analysis of the network meaning of the Gospel of Mark's description of the baptism of Jesus by making explicit that the symbolic image of the Spirit descending upon Jesus refers to the symbolic image of the Spirit hovering over the waters in Genesis. I could continue this for as long as my familiarity with the semiotic code allowed without ever leaving the system of symbols that make up the Christian scriptures - without ever

\footnotetext{
${ }^{180}$ Robert C. Neville, Religion in Late Modernity, 185.

${ }^{181}$ Robert C. Neville, Religion in Late Modernity, 186.

182 Robert C. Neville, Religion in Late Modernity, 186.

${ }^{183}$ Robert C. Neville, Religion in Late Modernity, 49.
} 
engaging with reality. But this is not to suggest, in post-structuralist fashion, that there is nothing beyond the text. This suggestion confuses the structure of network meaning with the structure of content meaning. ${ }^{184}$ Neville writes that "signs have content meaning when a person is able to use them, along with the relevant referents and interpretants in their coded network, to refer to and interpret realities so as to shape and be shaped through engagement." 185 Thus, the ability to grasp the content meaning of a symbol system is relative to the secondary referent, as outlined above. And while content meaning is the more important in the sense that through content meaning, reality is engaged, this is not to deny the importance of network meaning in interpretative engagement. For often it is a network of symbols that an interpreter uses to engage reality rather than a single, isolated symbol.

Neville observes that network meaning is often learned in religious community long before the symbols might be used to interpret finite/infinite contrasts. For instance, Neville writes that "childhood vests one with a host of . . symbols of religious matters. These symbols are picked up from the media, from school, perhaps from participation in a religious community, and from friends who have their own religious communities.","186 One often becomes acquainted with the network meaning of religious symbols to some degree in community and only later have an experience that, as Neville phases it, "shocks the person suddenly to see the limits, the particularity, the peculiarity, the finiteness of the life-world."187 This might be an experience of natural sublimity, an awareness of deep moral obligation, or the facing of disease or death. Either way, the person becomes

\footnotetext{
${ }^{184}$ Robert C. Neville, Religion in Late Modernity, 49.

${ }^{185}$ Robert C. Neville, Religion in Late Modernity, 186.

${ }^{186}$ Robert C. Neville, The Truth of Broken Symbols, 163.

187 Robert C. Neville, The Truth of Broken Symbols, 163.
} 
somewhat conscious of the spiritual dimension of life. If they have inherited religious symbols from their community, they may quite naturally translate such experiences in terms of these ready-made systems. Keeping in mind that for Neville the term 'divine' simply means a finite/infinite contrast, he notes that "the point to be emphasized is the shift from merely interpreting one's life within the play of religious symbols to using those symbols to engage the divine. This requires actual interpretive engagements of the divine, often sparked by limit-situation encounters, by employing symbols intentionally."188

\section{Religious Emotions}

With this much of Neville's theory of religious symbolism in place, we can begin to explore how it can contribute to a philosophical analysis of religious emotions. To illustrate this potential, I will begin by reviewing one of the few, if not the only, philosophical analyses of the concept of religious emotion. I will then show how understanding religious emotions as psychosomatic forms of transformational concern with religious symbols interpreted in a devotional context as their object can contribute to this work.

In his article "What are Religious Emotions?", Petri Järveläinen employs a weak/liberal version of cognitivism to offer an account of religious emotions. In considering the conditions for an emotion in general, he writes that "all emotions involve an affective feeling component and an evaluative cognitive component," where the cognitive component is conceived broadly to include thoughts, images, memories,

${ }^{188}$ Robert C. Neville, The Truth of Broken Symbols, 165. 
perceptions, etc. ${ }^{189}$ In addition to these two generic conditions, Järveläinen identifies three specific conditions for religious emotions. According to the cognitive object condition, Järveläinen states that "religious emotions involve a thought of the divine as their essential component," where "the term divine is an open term that does not define strictly any theological content. It just refers to something outside the human mind and world." Secondly, according to the depth condition, Järveläinen writes that "in order to be deemed religious, emotions have to be self-regarding" in the sense that they are existentially significant. ${ }^{191}$ For example, suppose someone stumbles upon a living nativity scene and experiences delight. This delight is not religious if it is simply a response to the quaintness of the scene. If a tourist in a Japanese temple experiences wonder at the sight of the images of the gods, this is not a religious wonder if the object of this wonder is merely the extraordinary craftsmanship of the temple and the representations of the gods or if the representations of the gods do not in some way signify one's commitments, personality, and ultimate concern. Finally, the existential significance of certain narratives, images, hymns, etc. are derived from the practical religious life. According to this pragmatic condition, Järveläinen writes that "emotions are religious if they are situated in, or are reminiscences of, religious practices.. ${ }^{, 192}$ Thus, according to Järveläinen, emotions are religious when the object of the emotion involves a thought of the divine that is apprehended as existentially significant though participation in a religious community.

\footnotetext{
${ }^{189}$ Petri Järveläinen, "What Are Religious Emotions?,” in Religious Emotions: Some Philosophical Explorations, ed. by Willem Lemmens and Walter Van Herck (Cambridge: Cambridge Scholars Publishing, 2008), 15-16.

190 Petri Järveläinen, "What are Religious Emotions?," 18-19.

191 Petri Järveläinen, "What are Religious Emotions?," 20.

192 Petri Järveläinen, "What are Religious Emotions?," 22.
} 
For reasons given in chapter one, I do not fully accept Järveläinen's cognitivist understanding of emotion and do not think he pays enough attention to conative elements of emotion. However, I do think that Järveläinen's three conditions for religious emotions at least provide a good starting point for discussing the concept of religious emotion. According to Järveläinen's cognitive object condition, the object of religious emotions is a thought of the divine, where the divine refers to the transcendent, "something outside the human mind and world."193 However, it is difficult to see how the transcendent, as such, could possibly serve as an object of experience, much less of sensory apprehension in the Thomistic sense. This difficulty is acute only if one recognizes the categorical difference between ordinary objects and the transcendent. For instance, in his book Perceiving God, William Alston assumes that a non-sensory perception of God is possible and argues that this type of religious experience is normative based on the nature of God. He writes, "It seems clear that a non-sensory appearance of a purely spiritual deity has a greater chance of presenting Him as He is than any sensory presentation."194 However, Alston's language of 'a purely spiritual being' fails to appreciate this categorical difference (by making the transcendent out to be some sort of all-powerful ghost) and, as a result, fails to appreciate the problem of religious experience. As Nick Zangwill argues, "[God] is so different that we should doubt whether there are and could be perceptual experiences of [God]."195 Järveläinen's definition of the divine as something outside the mind and world recognizes this

\footnotetext{
193 Petri Järveläinen, "What are Religious Emotions?," 18-19.

${ }^{194}$ William Alston, Perceiving God: The Epistemology of Religious Experience (Ithaca, NY: Cornell University Press, 1993). 20.

${ }^{195}$ Nick Zangwill, “The Myth of Religious Experience,” Religious Studies 40 (2004): 3.
} 
categorical transcendence, but he does not offer an explanation for how the divine so conceived could possibly serve as an object of emotion.

Applying Neville's theory, I want to suggest that the transcendent as such is not and could not be the object of religious emotions, for it cannot be the object of cognition. Qualifying Järveläinen's cognitive object condition, I define the object of religious emotions not as the infinite or the transcendent as such, but as intentionally interpreted schema images of finite/infinite contrasts in a devotional context. This revision of the cognitive object condition not only allows for the object to be a possible object of emotion, but it also explains why the depth condition and the pragmatic condition are necessary for the concept of religious emotion. Precisely because the symbolic images refer (directly or indirectly) to limit experiences and are interpreted as having content meaning, such emotional concerns will be existentially significant and meet Järveläinen's depth condition. Finally, symbolic intentional interpretations of finite/infinite contrasts are only possible when one has achieved a certain degree of fluency in the network meaning of some symbolic system. These symbolic systems and network meaning are always culturally embedded and acquired through participation in community. As a result, religious emotions will be, as Järveläinen states, "situated in, or are reminiscences of, religious practices."196 Thus, Neville's theory of religious symbolism contributes to Järveläinen's discussion of religious emotion not only by qualifying the cognitive object of the emotion, but also by allowing us to see the connection between the three specific conditions of religious emotion.

There is an additional contribution made by Neville's distinction between the iconic and indexical modes of reference. His emphasis on indexical reference in the

\footnotetext{
${ }^{196}$ Petri Järveläinen, "What are Religious Emotions?," 22.
} 
devotional context allows for a wide variety of images to potentially serve as religious symbols. Indexical reference allows religious symbols to be "far more fantastical and imaginatively extreme than those in theological or social contexts." ${ }^{197}$ As a result, there are a wide variety of religious emotions. Scholars studying religious emotions from a variety of disciplines increasingly hold the view that religious emotions are not limited to a particular type. For instance, Robert Roberts writes that "Religious emotions . . come in most standard emotion-types: joy, sorrow, fear, gratitude, hope, anger, awe, reverence, compassion, contrition, hatred."198 Similarly, sociologists Ole Riis and Linda Woodhead state that "[a religious emotion] is not some distinctive experience, sensation, or identifiable set of emotions. When a writer like Rudolf Otto (1994/1931) tries to identify authentic religion with a particular type of feeling (a sense of mysterium tremendum et fascinans), or when Karen Armstrong (2007) says that 'all religions are designed to teach us how to live, joyfully, serenely, and kindly, in the midst of suffering,' they take a wrong turn." ${ }^{\prime 199}$ There is no religious emotion per se; rather, any emotion can be religious. Like Armstrong, I focus on the transformative aspect of religion, but joy and serenity are not the only emotions aroused by religious objects. Nor do all traditions share the same conception of the soteriological end. In continuing to develop this account of religious emotions, the next two chapters illustrate this wide diversity of religious emotions, religious ends, and the connection between the two.

\footnotetext{
${ }^{197}$ Robert C. Neville, Religion in Late Modernity, 60.

${ }^{198}$ Robert Roberts, "Emotions Research and Religious Experience," in The Oxford Handbook of Religion and Emotion, ed. John Corrigan (Oxford: Oxford University Press, 2008), 493.

${ }^{199}$ Ole Riis and Linda Woodhead, A Sociology of Religious Emotions (Oxford: Oxford University Press, 2010), 54.
} 


\section{CHAPTER THREE}

\section{AN ANALYSIS OF RELIGIOUS EMOTIONS OF ATTRACTION}

\section{Introduction}

In chapter one, I articulated and argued for the Thomistic account of the emotions as psychosomatic forms of transformational concern toward objects of sensory apprehension. Chapter two was primarily concerned with specifying the object of religious emotions as religious symbols interpreted in a devotional context. My primary aim of the next two chapters is to argue that understanding religious emotions as psychosomatic forms of transformational concern toward devotional symbols of ultimacy can provide a fruitful framework for analyzing specific religious emotions and comparing religious emotional experiences across religious traditions. In order to illustrate the wide diversity and variety of religious emotions, the organization of this chapter and the next mirrors Aquinas's list of basic passions. This chapter will consider the five passions of attraction (love, longing, joy, hope and despair) and the next will consider five passions of repulsion (hate, disgust, sorrow, fear and anger). One advantage of Aquinas's theory, which I hope will become apparent, is its ability to illustrate not only the logic of particular emotions considered by themselves, but also the various relationships and connections among particular emotions. These connections will be particularly

illuminating when considered in a religious context. Since the first chapter was primarily focused on Aquinas's account of the emotions generally, I will begin by offering an 
analysis of Aquinas's account of the specific passions of attraction. I will then analyze religious examples of these passions (or close analogues of these passions) from diverse traditions (Judaism, Islam, Hinduism, and Buddhism) on the framework developed in the previous two chapters. Considering each emotion in its generic form first will allow me to illustrate how sensitivity to the relationship between the passions and common patterns of emotion can illuminate commonalities and diversity of values within and between religious traditions. While this chapter is focused on the passions of attraction, there are also important connections and patterns between certain passions of attraction and passions of repulsion, for example between love and hate or between longing and sorrow. These connections will be addressed in the following chapter. Once this analysis and application is illustrated for both the passions of attraction and repulsion, I will be in a position to begin to explore the relationship between religious emotion and religious belief and practice.

\section{The Passion of Love}

Usage of the term 'love' is highly varied. We speak of loving a spouse, loving our child, loving a pet, loving wine, the love of reading, the love of wisdom, and the love of God. For Aquinas, love (amor), in its most proper sense, is a passion. As such, the passion of love is a principle or fundamental inclination of the sensitive appetite toward some particular cognized good. However, other usages of the term love are legitimate by way of analogy. For instance, we may speak of a plant loving the sun because, like love in its proper sense, this natural love exhibited in the plant is a principle of movement 
toward some suitable end, ${ }^{200}$ but unlike love proper, this suitable object is not perceived by the plant. It can be analogously said that the philosopher loves wisdom or that the prophet loves justice, but, like natural love, this is love only in "a wider and extended sense," 201 for the object, while cognized, is not particular. Aquinas thus avoids the claim that the usages of the term 'love' in these widely varied contexts are complete equivocations. They are all fundamental inclinations toward some good. But in its proper sense, amor refers to the passion of love. As a passion, Aquinas writes that "the first change wrought in the [sensitive] appetite by the appetible object is called 'love,' and is nothing else than complacency in that object; and from this complacency results a movement towards that same object, and this movement is 'desire;' and lastly there is rest which is 'joy.",202 For Aquinas, the passion of love is not a movement of the appetite towards an object, but a principle of movement. Love, in this sense, is the root of and grounds for all the other passions. This description of love as a principle of movement allows Aquinas to explain how, according to the ordinary usage of the term, love can persist through various emotional states. For instance, a parent's love for their child persists whether the parent is missing (longing for) or enjoying the company of the child.

Robert Roberts reserves the term 'attachment' to refer to this principle at the root of other passions, but observes some of the same central features as Aquinas. "A significant part of the evidence that a person has an attachment to someone is the emotions that he or she experiences in response to the vicissitudes of the attachment's

\footnotetext{
200 Thomas Aquinas, Summa Theologiae I-II, q. 26, a. 1, trans. Fathers of the English Dominican Province (New York: Benzinger Bros., 1948).

${ }^{201}$ Thomas Aquinas, Summa Theologiae I-II, q. 26, a. 2, trans. Fathers of the English Dominican Province (New York: Benzinger Bros., 1948).

202 Thomas Aquinas, Summa Theologiae I-II, q. 26, a. 2, trans. Fathers of the English Dominican Province (New York: Benzinger Bros., 1948). In this quote, 'complacency' is a translation of the Latin 'complacentia,' which in this context does not denote lazy self-satisfaction, but something like 'finding acceptable or suitable.'
} 
object." ${ }^{203}$ For example, out of attachment (love) for my wife, I experience joy at her success, anger at those who mistreat her, fear when she is endangered, etc. Given that attachment is a concern rather than a concern-based construal (as Roberts takes joy, anger, fear, and emotions generally to be), he resists identifying attachment as an emotion. "So far, I have suggested that love, in the dispositional sense of attachment, is not an emotion but a disposition to a range of emotions." ${ }^{204}$ But Aquinas makes explicit that love in the sense of attachment is a passion. "Since, therefore, love consists in a change wrought in the appetite by the appetible object, it is evident that love is a passion." 205 This is consistent with my reconstruction of Aquinas's theory of emotions as forms of concern (rather than construals) toward objects of sensory apprehension. Roberts even admits that we often correctly identify cases of simple attachment and appreciation as emotions of love. Roberts simply marks these experiences as exceptions to his paradigm where such experiences are the concern itself rather than a construal based on a concern. $^{206}$ By identifying the emotions generally with the conative concern element rather than the cognitive construal element, the Thomistic theory captures our intuition that such cases are emotions.

Aquinas identifies two necessary elements involved in the passion of love: amor concupiscentiae (desirous love) and amor amicitiae (friendship love). Aquinas remarks that "the movement of love has a twofold tendency: towards the good which a man wishes to someone (to himself or to another) and towards that [person] to which he

\footnotetext{
${ }^{203}$ Robert C. Roberts, Emotions: An Essay in Aid of Moral Psychology (Cambridge: Cambridge University Press, 2003), 286.

${ }^{204}$ Robert C. Roberts, Emotions: An Essay in Aid of Moral Psychology, 288.

205 Thomas Aquinas, Summa Theologiae I-II, q. 26, a. 2, trans. Fathers of the English Dominican Province (New York: Benzinger Bros., 1948).

${ }^{206}$ Robert C. Roberts, Emotions: An Essay in Aid of Moral Psychology, 288.
} 
wishes some good. Accordingly, man has love of concupiscence towards the good that he wishes to another [or herself], and love of friendship towards him [or her] to whom he wishes some good. ${ }^{207}$ For Aquinas, every instance of the passion of love will contain both of these elements. Also, it is important to emphasize that the friend in friendship love is often simply oneself, not necessarily another person. I love the beer I am drinking at the moment with desirous love, but it is because I love myself with friendship love (because I desire good for myself) that I love the perceived good of beer. Additionally, friendship love is always primary and desirous love is derivative. If I did not love myself, I would not love the beer. Finally, our love for others can take either form. If I love someone merely for what they can do for me, the other is the object of my desirous love, not my friendship love. In such a case, the object of my friendship love is myself. Aquinas assumes that love of another for their own sake is possible and that the love of friendship can reach beyond the boundaries of the self. But if we love someone merely for the way their qualities fulfill some desire we have (they make us laugh, their wit is intellectually stimulating, their physical beauty is pleasing), the primary object of love is not the other person but the self.

Aquinas's distinction between desirous love and friendship love separates his account from what Eleonore Stump refers to a "the responsiveness account of love."208 On this account, love is simply a response to qualities the lover values in the beloved. One major weakness of such an account concerns its difficulty in explaining the specificity of love. If my love for my wife is a response to her physical beauty, her

\footnotetext{
207 Thomas Aquinas, Summa Theologiae I-II, q. 26, a. 4, trans. Fathers of the English Dominican Province (New York: Benzinger Bros., 1948).

${ }^{208}$ Eleonore Stump, "Love, By All Accounts," Proceedings and Addresses of the American Philosophical Association 80 (2006): 25.
} 
charm, or her intelligence, then why do I not love others who have these qualities in an even greater abundance? For Aquinas, such an account may be able to explain desirous love of another, but in such a case the primary object of love is the self, not the other. But if it is not because of the perceived qualities of the other that I have friendship love for the other, then how is genuine friendship love of another possible?

Aquinas's implicit answer to this question can be gleaned in his elaboration on the nature of friendship love as a union of affection (secundum affectum), which is distinguished from real union (secundum rem). ${ }^{209}$ Real union involves the lover being in the presence of the beloved, which is simply an effect of love because "love moves man to desire and seek the presence of the beloved, as of something suitable and belonging to him. ${ }^{, 210}$ The union of affection, however, is a richer notion and part of the very nature of friendship love. Whereas real union is caused effectively by love, Aquinas states that union of affection is "caused formally by love, because love itself is this union or bond." 211 In terms of how the union of affection applies to friendship love of others, Aquinas writes, "in love of friendship the lover identifies with his friend, regarding his fortunes and his very will as his own. . . L Loving takes us out of ourselves. It disposes us to intense preoccupation of thought with the beloved and abstracts us from other things." 212 The union of affection that constitutes love occurs in friendship when the distinction between the lover's interest and the interests of the beloved breaks down such that the lover "reckons what is good or evil to his friend, as being so to himself; and his

\footnotetext{
209 Thomas Aquinas, Summa Theologiae I-II, q. 28, a. 1, trans. Fathers of the English Dominican Province (New York: Benzinger Bros., 1948).

210 Thomas Aquinas, Summa Theologiae I-II, q. 28, a. 1, trans. Fathers of the English Dominican Province (New York: Benzinger Bros., 1948).

211 Thomas Aquinas, Summa Theologiae I-II, q. 28, a. 1, trans. Fathers of the English Dominican Province (New York: Benzinger Bros., 1948).

212 Thomas Aquinas, Summa Theologiae I-II, q. 28, a. 2, trans. Timothy McDermott (Notre Dame: Ave Maria Press, Inc., 1991), 207.
} 
friend's will as his own will." ${ }^{213}$ This results in a kind of sober ecstasy, according to Aquinas, for the lover is taken out of herself by caring and providing for the beloved for their own sake. ${ }^{214}$ When this occurs, the lover transcends his or her predisposition to desire things merely as a means to his or her own gratification. According to Thomas Miner's interpretation of Aquinas's account, friendship love may begin with desirous love but goes beyond it. We may be initially attracted to another for how they fit into our plans and how they serve our own ends. But friendship love moves beyond this to an affirmation of the other for their own sake. ${ }^{215}$

Love as union also has its modern defenders. For example, Roger Scruton, writing more specifically on romantic love, writes that the "friendship of esteem becomes love just so soon as reciprocity becomes community: that is, just so soon as all distinction between my interests and your interests is overcome." ${ }^{216}$ Critics of this type of union theory of love charge that it implies a loss of individual autonomy of the sort which is necessary for love. ${ }^{217}$ However, Aquinas can avoid some of the force of this criticism because he would not go so far as to say all distinctions between the lover's and the beloved's interests are overcome. Individuality is not lost in the type of union Aquinas describes. Instead, lovers "seek a suitable and becoming union — to live together, speak together, and be united together in other like things." ${ }^{218}$ Notice Aquinas does not say lovers seek to be united in all like things. Perhaps Aquinas's account of the union of love

\footnotetext{
${ }^{213}$ Thomas Aquinas, Summa Theologiae I-II, q. 28, a. 2, trans. Fathers of the English Dominican Province (New York: Benzinger Bros., 1948).

${ }^{214}$ Thomas Aquinas, Summa Theologiae I-II, q. 28, a. 3, trans. Fathers of the English Dominican Province (New York: Benzinger Bros., 1948).

${ }^{215}$ Thomas Miner, Thomas Aquinas on the Passions, 125-6.

${ }^{216}$ Roger Scruton, Sexual Desire: A Philosophical Investigation (London: Continuum, 2006), 230.

${ }^{217}$ See Irving Singer, The Pursuit of Love (Baltimore: John Hopkins University Press, 1994).

${ }^{218}$ Thomas Aquinas, Summa Theologiae I-II, q. 28, a. 1, trans. Fathers of the English Dominican Province (New York: Benzinger Bros., 1948). Emphasis added.
} 
is closer to Neil Delaney's theory, who argues that love is like a wish among sovereign sates to form a republican nation. A sovereign state recognizes that their own well-being is intimately connected with the well-being of the other states, but also appreciate the independence and sovereignty of the others. Similarly, in friendship love, the lover can appreciate the distinctiveness of the beloved, while also understanding that their own interest is intimately connected with the interests of the beloved. ${ }^{219}$

A related criticism of union theories claims that having concern for another simply for their own sake, which is taken to be at the very essence of love, is unintelligible on the union view. Bennett Helm writes that "by doing away with the distinction between my interests and your interests they have in effect turned your interests into mine and vice versa."220 The crux of this criticism as it applies to Aquinas is that friendship love of another is impossible if love formally is this union, and thus all love of others would be forms of desirous love. If the lover regards the fortunes of the beloved as her very own, then the good of the beloved is in the interest of the lover, and the lover fails to love the beloved simply for their own sake. While Aquinas does hold that friendship love is loving another for their own sake, he never claims such love is simply for the other's sake. We can make a distinction between disinterested love, which I think Aquinas would find unintelligible as a passion, and loving another for their own sake. In distinguishing friendship love from desirous love, Josef Pieper writes that "the test question ... is not: Do you find the other person likable, capable, 'nice'? Rather, the test question is: Are you glad for his existence, or do you have anything against it; can

\footnotetext{
${ }^{219}$ Neil Delaney, "Romantic Love and Loving Commitment: Articulating a Modern Ideal," American Philosophical Quarterly 33 (1996): 341-2.

${ }^{220}$ Helm, Bennett, "Love," The Stanford Encyclopedia of Philosophy (Fall 2009 Edition), ed. Edward N. Zalta, URL $=<$ http://plato.stanford.edu/archives/fall2009/entries/love/ $>$.
} 
you honestly say, 'It's good that he exists'?"221 For Aquinas, it is the union of affection that allows for an affirmative answer to this question, but this will necessarily entail that the lover is interested in the good of the beloved. Aquinas explains, "When a man loves another with the love of friendship, he wills good to him, just as he wills good to himself: wherefore he apprehends him as his other self."222 I may desire the good for my friend and, due to the union of interests, perceive the good of my friend to also be in my interest. But, in the love of friendship, I do not desire the good of my friend because it is in my interests, but because it is for the good of my friend.

Aquinas further analyzes particularly human forms of the passion of love by exploring its relationship to reason and the will. In this context, Aquinas distinguishes between the concepts of amor, dilectio, and caritas. "For love [amor] has a wider signification than the others, since every dilection [dilectio] or charity [caritas] is love, but not vice versa. Because dilection implies, in addition to love, a choice made beforehand ... and therefore dilection is ... only in the rational nature. Charity denotes, in addition to love a certain perfection of love, in so far as that which is loved is held to be of great price." ${ }^{\mathbf{2 2 3}}$ When Aquinas states that every dilection is love (amor), but not necessarily vice versa, he is referring to love in its wider usage as a principle of movement toward some suitable end. Given Aquinas's psychology, dilection as a pure affection of the will could not be a sensitive passion. So, every dilection is a principle of movement toward some suitable end, but no dilection is amor in the proper sense of a passion.

${ }^{221}$ Josef Pieper, Faith, Hope, Love (San Francisco: Ignatius Press, 1997), 205.

222 Thomas Aquinas, Summa Theologiae I-II, q. 28, a. 1, trans. Fathers of the English Dominican Province (New York: Benzinger Bros., 1948). Emphasis added.

${ }^{223}$ Thomas Aquinas, Summa Theologiae I-II, q. 26, a. 3, trans. Fathers of the English Dominican Province (New York: Benzinger Bros., 1948) 
I want to suggest that the distinction Aquinas makes between the passion of love (amor) and rational love (dilectio) is similar to a distinction Bennett Helm makes between caring and valuing. Caring, for Helm, involves both seeing something as worth pursuing and to have a projectable pattern of emotional responses involving the object, i.e. "to be afraid when its accomplishment is threatened, to be hopeful when it might well be achieved, to be angry at those who impede one's progress, to be frustrated at repeated failures, etc." ${ }^{224}$ Like Aquinas's love, caring provides the foundation for other emotional responses. Helm continues by observing that "there is a difference between those things one happens to care about and those things one cares about at least in part because of an understanding of the kind of person one finds worth being. We therefore need to distinguish between what one cares about and, I shall say, what one values: to value something is to be concerned with caring about it ... because of such an understanding." 225 To illustrate this distinction, Helm offers an example of a workaholic father whose career drive is negatively affecting his relationship with his family. He is able to understand on an intellectual level he and his children are missing out on something important given his focus on his career, but he feels no great loss. ${ }^{226} \mathrm{He}$ values family relationships in that he intellectually judges it to be important, but he does not care for his family on an emotional level.

Being housed in the rational soul, the objects of dilection are universals (courage, kindness, beauty, etc.), as are values. When Aquinas notes that dilection involves a choice, he is observing that we freely assent to our values in a way we do not with what we care about. The workaholic father, given his values, may want to care about his

\footnotetext{
${ }^{224}$ Bennett W. Helm, "Freedom of the Heart," Pacific Philosophical Quarterly 77 (1996): 76.

${ }^{225}$ Bennett W. Helm, "Freedom of the Heart," 78.

${ }^{226}$ Bennett W. Helm, "Freedom of the Heart," 72.
} 
family, even though he does not. Aquinas also notes that dilection involves a choice made before love. This is in concert with his view that the intellective soul (reason and will) has limited and indirect control over the passions. For example, reason can control the passions though its influence on the imagination as discussed in chapter one. ${ }^{227}$ Also, Helm's example of the workaholic father can explain why Aquinas warns the reader against supposing that dilection is a superior form of love simply because it occurs in the rational appetite: "But it is possible for man to tend to God by love, being as it were passively drawn by Him, more than he can possibly be drawn thereto by reason, which pertains to the nature of dilection, .... And consequently love is more Godlike than dilection." 228 Thomas Miner notes how this passage undermines the conventional wisdom that the most relevant form of love for rational creatures is one that proceeds from an act of will. "Amor sensitivus cannot be neglected by the rational creature in its motion toward God. . . . Lacking the energy of the sensitive appetite, the amor intellectualis Dei will be weak."

Helm's distinction can also help us understand Aquinas's remark on charity as the perfection of love. In Helm's language, charity is the freedom of the heart: "One's heart is free just in case one is able successfully to control what one in fact cares about, what heart one in fact has, and it is one's values that motivate this control."230 Charity, like freedom of the heart, occurs when "that which is loved is held to be of great price

\footnotetext{
227 Thomas Aquinas, Summa Theologiae I-II, q. 17, a. 7, trans. Fathers of the English Dominican Province (New York: Benzinger Bros., 1948).

${ }^{228}$ Thomas Aquinas, Summa Theologiae I-II, q. 26, a. 3, trans. Fathers of the English Dominican Province (New York: Benzinger Bros., 1948).

229 Thomas Miner, Thomas Aquinas on the Passions, 122.

${ }^{230}$ Bennett W. Helm, "Freedom of the Heart," 72.
} 
[value]. ${ }^{.231}$ Charity is present when our values ground and give shape to our love. This is precisely why charity, unlike amor or dilectio considered in themselves, is a virtue. Suppose the workaholic father, in a manner reminiscent of Kant's (in)famous philanthropist, has no emotional care for his family, but still manages to fulfill his duties as a father by showing up to every little league game, music recital, and birthday party (despite feeling guilt for being away from the office for even short period of time) simply because he intellectually recognizes the value of such actions. For Aquinas, the father may display continency and perseverance, but he lacks moral virtue because his rational values have not given proper shape to his passions. ${ }^{232}$

Thus far, Aquinas has only remarked on the formal aspects of love and its relation to reason and will. However, he also has much to say on the instrumental value of love. Aquinas notes the transformational nature of love on the subject, but is explicit that this transformation can be either for the better or for the worse. "Love of a suitable good perfects and betters the lover; but love of a good which is unsuitable to the lover wounds and worsens him."233 Aquinas observes that love can bring ecstatic fulfillment, selfless attitudes, and is necessary for friendship, ${ }^{234}$ but it can also cause excessive zeal, jealousy, envy, and even hatred. ${ }^{235}$ Nancy M. Martin and Joseph Runzo similarly note this duality of love in a religious context: "If the power of the emotion of love is not harnessed for self-transformation, then rather than enhancing the other-regarding perspective prescribed

${ }^{231}$ Thomas Aquinas, Summa Theologiae I-II, q. 26, a. 3, trans. Fathers of the English Dominican Province (New York: Benzinger Bros., 1948).

${ }^{232}$ See Thomas Aquinas, Summa Theologiae I-II, q. 58, a. 3, trans. Fathers of the English Dominican Province (New York: Benzinger Bros., 1948).

${ }^{233}$ Thomas Aquinas, Summa Theologiae I-II, q. 28, a. 5, trans. Fathers of the English Dominican Province (New York: Benzinger Bros., 1948).

${ }^{234}$ Thomas Aquinas, Summa Theologiae I-II, q. 28, a. 3, trans. Fathers of the English Dominican Province (New York: Benzinger Bros., 1948).

${ }^{235}$ Thomas Aquinas, Summa Theologiae I-II, q. 28, a. 4, trans. Fathers of the English Dominican Province (New York: Benzinger Bros., 1948). 
by religion, this emotion can increase attachment, partiality, and self-centeredness." 236

Finally, for Aquinas, love is the source of all human agency. "Every agent acts for an end, .... Now the end is the good desired and loved by each one. Wherefore it is evident that every agent, whatever it be, does every action from love of some kind."237 As the qualifier 'of some kind' suggests, Aquinas does not hold that every human action is rooted in the passion of love, but love in the broader sense as a principle of movement toward some end. The workaholic father's attendance at the little league game was rooted in rational love, but not the passion of love. This is not to dismiss the passion of love as superfluous. As we saw, Aquinas holds the passions to be necessary for virtuous action. Also Robert Miner notes, "Amor sensitivus constitutes the natural starting-point for love as experienced by the embodied creature. It is . . the soil from which rational love grows." Given this, sensitive love also serves as the foundation for the virtue of charity.

\section{The Passion of Longing}

While Aquinas devotes three full questions with a total of fourteen articles to the passion of love, the passion of longing demanded only a third of this treatment. ${ }^{238}$ But in this short space, Aquinas makes a couple of important distinctions that will clarify not only the logic of longing, but other passions as well, particularly as they occur in the human animal. In a manner similar to his treatment of amor, Aquinas begins by

\footnotetext{
${ }^{236}$ Nancy M. Martin and Joseph Runzo, "Love," in The Oxford Handbook of Religion and Emotion, ed. John Corrigan (Oxford: Oxford University Press, 2008), 310.

${ }^{237}$ Thomas Aquinas, Summa Theologiae I-II, q. 28, a. 6, trans. Fathers of the English Dominican Province (New York: Benzinger Bros., 1948).

${ }^{238}$ Aquinas uses the term concupiscentia to refer to this passion. This is usually translated as either 'concupiscence' or 'desire.' I prefer the term 'longing' to 'concupiscence' due to the rare usage of 'concupiscence' in contemporary English. I prefer 'longing' over 'desire' for reasons that will become clear in my analysis of Aquinas's theory.
} 
distinguishing concupiscentia in its proper sense as a passion from its extended sense as a pure affection of the will. He defines concupiscentia as "a craving for that which is pleasant," but notes this could refer to something intelligible (the desire for wisdom) or something perceptible to the senses. He writes, "Now concupiscence seems to be the craving for this latter pleasure, since it belongs to the united soul and body, as is implied by the Latin word 'concupiscentia.' Therefore, properly speaking, concupiscence is in the sensitive appetite, which takes its name from it." ${ }^{\prime 239}$ Aquinas's insistence that concupiscentia is a passion leads me to prefer the term longing to desire. Aquinas notes the term desiderium (desire) can be used properly as a pure affection, whereas concupiscentia is only used this way in an extended sense. Likewise, the term "desire" can refer to non-emotional states like motivation or preference, while longing has an emotional connotation.

Aquinas further elaborates the structure of longing by showing it in relation to love and delight. All three of these passions are directed at some object perceived to be valuable in some way. But since specific passions are distinguished by their formal object, more needs to be said to distinguish longing from love and delight. Aquinas argues that it is possible to perceive a single sensible good under difference aspects, and it is these aspects that distinguish the formal objects of love, longing and joy. Aquinas explains, "Wherefore the object of sensible pleasure causes love, inasmuch as, so to speak, it attunes and conforms the appetite to itself; it causes concupiscence, inasmuch as, when absent, it draws the faculty to itself; and it causes pleasure, inasmuch as, when present, it makes the faculty to find rest in itself. Accordingly, concupiscence is a

\footnotetext{
${ }^{239}$ Thomas Aquinas, Summa Theologiae I-II, q. 30, a. 1, trans. Fathers of the English Dominican Province (New York: Benzinger Bros., 1948).
} 
passion differing in species from both love and pleasure." ${ }^{240}$ Longing entails seeing the good as absent; and delight or joy involves perceiving the suitable object as obtained or present. Successfully writing a published book may be an object of longing (and hope), but it would not be in the logic of joy for me to rejoice now at successfully getting a book published months from now.

Aquinas concludes his treatment of longing by examining particularly human forms of the passion as it interacts with the intellect and will. In this context, Aquinas draws an important distinction between natural and non-natural longing. Natural longing, which is common to animals and humans, has as its object something suitable to the nature of the animals, i.e. food, drink, etc. The object of non-natural longing, which is peculiar to the human animal, is "pleasurable because it is apprehended as suitable to the animal: as when one apprehends something as good and suitable, and consequently takes pleasure in it." ${ }^{, 241}$ One aspect of this distinction involves the notion that natural longing has as its object something that is naturally pleasurable based on the biology of the organism, whereas the object of non-natural longing results in joy only because the object is understood as good and suitable. For example, I would be joyous upon winning this week's lottery, but only because I understand money as instrumentally valuable. Thus, my longing to win the lottery is a non-natural form of longing. This distinction will be important to religious forms of longing, for at least at first glance they will be of the nonnatural variety. Aquinas goes on to explain the close interaction of non-natural longing with reason and the imagination: "Man has not only universal reason, pertaining to the

\footnotetext{
240 Thomas Aquinas, Summa Theologiae I-II, q. 30, a. 2, trans. Fathers of the English Dominican Province (New York: Benzinger Bros., 1948).

${ }^{241}$ Thomas Aquinas, Summa Theologiae I-II, q. 30, a. 3, trans. Fathers of the English Dominican Province (New York: Benzinger Bros., 1948). Emphasis added.
} 
intellectual faculty, but also particular reason pertaining to the sensitive faculty, ... so that even rational [non-natural] concupiscence may pertain to the sensitive appetite. Moreover the sensitive appetite can be moved by the universal reason also, through the medium of the particular imagination." ${ }^{242}$ Here again Aquinas notes the rich interplay between reason and perception. Like Wittgenstein's notion of 'seeing-as,' Aquinas holds that we perceive particular objects as instances of universal concepts. Additionally, universal concepts give shape to our imagination and move the sensitive appetite by means of these images.

Before considering joy, one particular form of human longing needs to be considered —compassion. Aquinas writes that "compassion is heartfelt identification with another's distress, driving us to do what we can to help. ${ }^{243}$ For Aquinas, compassion is a type of combination of sorrow and desire. It is sorrow in that its object is the suffering of another (an evil), but it is also the longing to alleviate the suffering, and alleviation of suffering is a good. So it can be analyzed from two perspectives. I will have more to say about compassion as a sorrow in the next chapter, but here I want to notice that compassion depends not just on love generally (as all passions do), but on friendship love of another specifically. Only through the union of affection is the lover able to identify with the distress of the beloved. If that identification were not possible, the longing to alleviate the suffering would not be possible either. It is only in the sober ecstasy of love that compassion has a home.

\footnotetext{
${ }^{242}$ Thomas Aquinas, Summa Theologiae I-II, q. 30, a. 3, trans. Fathers of the English Dominican Province (New York: Benzinger Bros., 1948).

${ }^{243}$ Thomas Aquinas, Summa Theologiae II-II, q. 30, a. 1, trans. Timothy McDermott (Notre Dame: Ava Maria Press, Inc,. 1991), 360.
} 


\section{The Passion of Joy}

In his treatment of delight, Aquinas's method is similar to his treatment of love and longing such that I can abbreviate my exegesis. He begins by analyzing delight as a passion generally, and then proceeds to examine particularly human forms of delight as it interacts with reason and the imagination, for which he reserves the term 'joy.' He begins by defining delight generally as a movement of the sensitive appetite in response to a perception of achieving a state becoming to the subject's nature and he again notes the relationship between longing and delight: "just as before it desired that which it had not, so afterwards does it delight in that which it possess." 244 He then distinguishes delight in general from the particular human form of it, joy. This distinction is made on the same grounds as he distinguished natural from non-natural concupiscence. "For we take delight both in those things which we desire naturally, when we get them, and in those things which we desire as a result of reason. But we do not speak of joy except when delight follows reason."245 As in the case of non-natural concupiscence, when reason is brought to bear on particulars, delight transforms into joy. But in this context, Aquinas adds a further complexity. "Now whatever we desire naturally, can also be the object of reasoned desire and delight, but not vice versa."246

The qualifier 'not vice versa' serves to distinguish the passion of joy (which occurs when reason bears on particulars though the imagination) from the pure affection of joy. As in the case of love, there is a pure affection corollary of both desire and joy

\footnotetext{
244 Thomas Aquinas, Summa Theologiae I-II, q. 31, a. 1, trans. Fathers of the English Dominican Province (New York: Benzinger Bros., 1948).

${ }^{245}$ Thomas Aquinas, Summa Theologiae I-II, q. 31, a. 3, trans. Fathers of the English Dominican Province (New York: Benzinger Bros., 1948).

${ }^{246}$ Thomas Aquinas, Summa Theologiae I-II, q. 31, a. 3, trans. Fathers of the English Dominican Province (New York: Benzinger Bros., 1948).
} 
which Aquinas describes as "the mere movement of the will."247 Again, I want to suggest that the relationship between the pure affection of desire and the passion of longing and the relationship between the pure affection of joy and the passion of joy is similar to the relationship between valuing and caring cited above. We might think of the pure affection of desire as something similar to what Harry Frankfurt terms a secondorder desire. ${ }^{248}$ For instance, someone may intellectually desire an improved relationship with their spouse, without ever being emotionally moved by this object. Or, perhaps more accurately stated, they have a desire to have a longing for an improved relationship with their spouse. They may, through sheer force of will, attend marriage counseling, while their longings pull them elsewhere. Aquinas quotes approvingly of Augustine when he writes that the pure affections of "desire and joy are nothing else but a volition of consent to things we wish." 249 In this passage, Aquinas seems to be citing a case where the will and the passions are in harmony such that one consents to the longings and passionate joys that they actually have. In his discussion on the will itself, Aquinas makes the second-order nature of the will in this respect even more explicit when he writes that "it is in the power of the will not to will to desire or not to consent to concupiscence. And thus it does not necessarily follow the movement of concupiscence., 250

\section{The Passions of Hope and Despair}

\footnotetext{
247 Thomas Aquinas, Summa Theologiae I-II, q. 31, a. 3, trans. Fathers of the English Dominican Province (New York: Benzinger Bros., 1948).

${ }^{248}$ See Harry Frankfurt, "Freedom of the Will and the Concept of a Person," The Journal of Philosophy 68(1971): 5-20.

${ }^{249}$ Thomas Aquinas, Summa Theologiae I-II, q. 31, a. 4, trans. Fathers of the English Dominican Province (New York: Benzinger Bros., 1948).

${ }^{250}$ Thomas Aquinas, Summa Theologiae I-II, q. 10 , a. 3, trans. Fathers of the English Dominican Province (New York: Benzinger Bros., 1948).
} 
Aquinas considers hope and despair under one question divided into eight articles.

He begins by distinguishing hope from longing, joy, and despair. He offers four necessary conditions for hope, which taken together are sufficient. First, like all other passions of attraction, the object of hope is some perceived good. Secondly, hope is distinguished from joy in that the perceived good is some future good. Thirdly, while hope presupposes longing, it is distinguished from longing in that that future good is perceived to be difficult to obtain. Finally, hope is distinguished from despair in that the perceived good is not considered impossible to obtain. ${ }^{251}$ For Aquinas, despair is, in a sense, contrary to hope, which might make it seem odd to classify it as a passion of attraction. However, despair (along with love, longing, joy, and hope) has some perceived good as its object. However, in despair the perceived good is seen as impossible to obtain. Precisely because both hope and despair share a difficult to obtain good object, hope can quickly turn to despair. But despite its sometimes negative connotation, for Aquinas, despair can be a valuable passion and is often crucial for survival. Despair can prevent us from chasing pipe dreams and redirect our energy to more worthwhile pursuits. ${ }^{252}$

This observation on despair is related to a seemingly odd question raised by Aquinas: "Whether Hope Abounds in Young Men and Drunkards?"253 Aquinas's objectors argue that since hope implies steadiness and power, which drunks and youth clearly lack, they obviously do not abound in hope. The point of this strange question

\footnotetext{
${ }^{251}$ Thomas Aquinas, Summa Theologiae I-II, q. 40, a. 1, trans. Fathers of the English Dominican Province (New York: Benzinger Bros., 1948).

${ }^{252}$ Aquinas makes this point in terms of a dog who despairs at catching a rabbit that is too far away to catch. If the rabbit is in fact too far away to catch, the dog's despair has survival value. Thomas Aquinas, Summa Theologiae I-II, q. 40, a. 4, trans. Fathers of the English Dominican Province (New York: Benzinger Bros., 1948).

${ }^{253}$ Thomas Aquinas, Summa Theologiae I-II, q. 40, a. 6, trans. Fathers of the English Dominican Province (New York: Benzinger Bros., 1948).
} 
and even stranger objection is the issue of false hope. Aquinas answers his objectors by observing that since the youth lack wisdom and experience, because they have not suffered defeat or become aware of their own shortcomings, they are prone to see unattainable goods as attainable. Likewise, drunks are foolish and thoughtless of dangers and, therefore, "attempt everything and are full of hope." For Aquinas, not only is despair not necessarily counter to human flourishing, hope is not necessarily conducive to human flourishing. If hope is the result of a false judgment about what is rational and appropriate to pursue, it is not a rational and virtuous hope. But if the object of hope is, in fact, possible to obtain and worth pursing, it serves the efficacy of action. Aquinas explains that "the thought of its being difficult arouses our attention; while the thought that it is possible is no drag on our effort." ${ }^{, 254}$ Ronald de Sousa notes this feature of emotions generally which he sees as "species of determinate patterns of salience among objects of attention, lines of inquiry, and inferential strategies." 255

Before turning to the religious context, one final passion, which is often associated with religion and spirituality, bears mentioning. Aquinas defines wonder as "a kind of desire for knowledge; a desire which comes to man when he sees an effect of which the cause either is unknown to him, or surpasses his knowledge or faculty of understanding." 256 As a form of desire, wonder can lead to joy in much the same way that longing in general leads to joy when the object of longing is obtained. But in this context, Aquinas argues that wonder can cause joy even if the object of wonder (knowledge) is not obtained. In addition to the joy of getting what one longs for, Aquinas

\footnotetext{
${ }^{254}$ Thomas Aquinas, Summa Theologiae I-II, q. 40, a. 8, trans. Fathers of the English Dominican Province (New York: Benzinger Bros., 1948).

${ }^{255}$ Ronald de Sousa, The Rationality of Emotion (Cambridge: MIT press, 1997), 196.

${ }^{256}$ Thomas Aquinas, Summa Theologiae I-II, q. 32, a. 8, trans. Fathers of the English Dominican Province (New York: Benzinger Bros., 1948).
} 
states that the "very increase of desire brings with it an increase of pleasure, according as it gives rise to the hope of obtaining that which is loved." ${ }^{, 257}$ Aquinas had previously argued that there can be delight in hope because hope involves a present appraising of some future good. ${ }^{258}$ Thus when wonder involves the hope of attaining knowledge, it too can produce pleasure. But Aquinas even suggests that wonder can involve joy when there is no hope due to the cause surpassing our knowledge or understanding. This occurs not because we obtain the knowledge we desired or because we hope to obtain it, but simply because "the wonderer learns something new, that the cause is other than he had thought it to be." ${ }^{259}$ In such cases, the cause of the joy in wonder is the knowledge that we do not and cannot know.

While Aquinas does not offer different terms for wonder-with-the-hope-ofknowledge and wonder-without-the-hope-of-knowledge, Robert Fuller offers a similar distinction between curiosity and wonder. Curiosity is associated with attempts to understand and perhaps manipulate one's environment. Wonder, on the other hand, is more passive. In wonder, one is more reflective on the meaning of the unexpected. ${ }^{260}$ This understanding of the logic of wonder leads Fuller to suggest that wonder is a particularly important emotion to study in a religious context. In response to unexpected stimuli, wonder engages cognitive reflection that is predisposed to grant reality to an unseen order that lies behind or beyond the mundane level of existence."261 While I

\footnotetext{
${ }^{257}$ Thomas Aquinas, Summa Theologiae I-II, q. 32, a. 8, trans. Fathers of the English Dominican Province (New York: Benzinger Bros., 1948).

${ }^{258}$ Thomas Aquinas, Summa Theologiae I-II, q. 32, a. 3, trans. Fathers of the English Dominican Province (New York: Benzinger Bros., 1948).

${ }^{259}$ Thomas Aquinas, Summa Theologiae I-II, q. 32, a. 8, trans. Fathers of the English Dominican Province (New York: Benzinger Bros., 1948).

${ }^{260}$ Robert C. Fuller, Wonder: From Emotion to Spirituality (Chapel Hill: University of North Carolina Press, 2006), 8.

${ }^{261}$ Robert C. Fuller, Wonder: From Emotion to Spirituality, 150.
} 
agree that wonder is an important emotion to study in a religious context, I am not sure it is any more important than other emotions. In fact, I hope to show in this chapter that paying close attention to the connections between various emotional states can be illuminating in a religious context. It is to this part of the project that I now turn.

\section{Religious Passions of Attraction}

In chapter two, I offered a working definition of religion as a set of interrelated and traditional human practices performed in response to perceived ultimacy with the end of individual, social, and/or global transformation. Robert Neville offers three models of spiritual transformation and perfection which, he claims, cuts across religious boundaries, although certain religious currents may stress one model over the others. The first model, which he labels the soldier, is centrally concerned with the purification of the will.

"According the ancient model, a soldier in the heroic mold must have psychic integrity to such a high degree as to be able to wholly devote himself or herself to life-threatening tasks." 262 Joshua, Arjuna, the samurai, and medieval knights are paradigm religious examples of this model. The second model, the sage, is a model of spiritual enlightenment and wisdom. Finally, the saint, is the model of the perfection of impulses of the heart. "Psychic integrity can keep these impulses in check, and enlightenment plus wisdom can tell what they ought to be; but altering them so as to have only good impulses is another kind of spiritual perfection."263 Of course the ideal of religious transformation is often held to be a transformation of the entire self — of knowing, doing, and feeling; of heart, soul, and might. But we can focus on the model of the saint

\footnotetext{
${ }^{262}$ Robert C. Neville, Solider, Sage, and Saint (New York: Fordham University Press, 1978), 1.

${ }^{263}$ Robert C. Neville, Solider, Sage, and Saint, 2.
} 
to explore how religious traditions use religious symbols to transform the sensitive appetite to better conform to perceived ultimacy.

My main objective in this section is to show how the Thomistic emotional framework and Neville's theory of devotional symbols can be applied in comparative religious projects focused on religious emotional experience. What follows is simply an attempt to briefly illustrate the potential. For this application, my guiding thesis is that in the emotional lives of the ideal saints across religious traditions (here I will focus on Judaism, Islam, bhakti Hinduism, and Mahayana Buddhism), one can detect a common emotional dialectical pattern: an oscillation of religious joy and religious longing. This pattern often transfers to a similar oscillation of religious hope and despair. Of course, none of these traditions are single, uniform entities, but long histories of experience and thought. I hope the reader will forgive my generalizations, but I hope focusing on the ideal-type of saint makes this generalization more justifiable. But either way, this is all in the interest of illustrating the application of the theoretical framework. Even if I do not convince the reader of my guiding thesis, I hope that, in my failure, I still illustrate the framework's promise.

\section{Judaism}

The central goal of the love of God in Judaism is illustrated in the Shema, the fundamental command and statement of faith in Judaism: "Here, O Israel: The Lord our God is one Lord. You shall love the Lord your God with all your heart, and with all your soul, and with all your might."264 Moses Maimonides notes the passional nature of this command, with its emphasis on the heart as well as the mind and will. "And what is the

${ }^{264}$ Dt. 6:4-5, NRSV. 
proper love? It is that a person shall love the Lord with a very mighty and overflowing love so that his soul shall be attached to the love of God, constantly dwelling on it, as one who is lovesick and cannot take his mind away from his love for a particular woman."265 Aquinas notes the somatic feeling of sickness as the material aspect of the passion of love generally. "But in respect of the material element in the passion of love, i.e. a certain bodily change, it happens that love is hurtful, by reason of the change being excessive."266 By emphasizing the somatic aspects of the love of God, Maimonides suggests that one should love God passionately as opposed to simply value God through an affection of the will. Apparently Maimonides, unlike Kant, thinks pathological love can be commanded. But how is passionate love, which according to our framework is always directed at an object of sensory apprehension, possible at all in a Jewish context given the transcendent nature of the ultimate as its "object"? Martin and Runzo offer a clue when they observe that the study of the Torah "occasions a free emotional expression of love directed at the text itself. ${ }^{, 267}$ Here the text as the word of God serves as the indexical symbol of ultimacy and as the proximate object of religious love. This symbol structure, while necessary to engender the passions, is also, in part, what lends religious emotions generally and religious love particularly their potential for harm. Martin and Runzo note that "in spite of the intense love enjoined in the Torah, care must be taken not to let the love of the Torah displace the love for God, who is its source."268

\footnotetext{
${ }^{265}$ Moses Maimonides, "The Guide for the Perplexed," in The Jewish Mystical Tradition, trans. Ben Zion Bokser (New York: Pilgrim Press, 1993), 80.

${ }^{266}$ Thomas Aquinas, Summa Theologiae I-II, q. 28, a. 5, trans. Fathers of the English Dominican Province (New York: Benzinger Bros., 1948).

${ }^{267}$ Nancy M. Martin and Joseph Runzo, "Love," in The Oxford Handbook of Religion and Emotion, ed. John Corrigan (Oxford: Oxford University Press, 2008), 315.

${ }^{268}$ Nancy M. Martin and Joseph Runzo, "Love," 315.
} 
As Aquinas states, "Love of a suitable good perfects and betters the lover; but love of a good which is unsuitable to the lover wounds and worsens him."269

The Jewish mystical traditions of Kabbalah and Hasidism often describe love, both of others and of God, in terms of union. The Kabbalah love of neighbor that is to be cultivated before entering a synagogue is described as a "sense of communal and interpenetrating identity. ${ }^{, 270}$ Hasidic Rabbi Shneur Zalman of Lyady speaks of the experience of love as the softening of the boundary between individual identity and God. This love, according to Zalman, takes place in two phases. The first phase is one of "wonderous delight in God, with a great, a mighty joy, the joy of the soul to the very limits of its strength." 271 The second stage is one of longing where the soul yearns "to cleave to God, to be included in the source of life." ${ }^{, 272}$ Here we see the quest for the love of God resulting in phases of joy and longing. Like Aquinas, the Rabbi understands love to be at the root of religious longing and joy, but interestingly disrupts the order such that longing follows joy rather than vice versa.

Part of the reason for this disruption has to do with the nature of religious symbols such that we might expect a similar disrupted pattern across religious traditions that conceive ultimacy as a transcendent ontological reality. On Neville's theory, religious symbols are "broken.” Drawing on Paul Tillich's idea of "broken myth," Neville introduces the phrase "broken symbol" to indicate the fact that religious symbols, while engaging the interpreter with what they symbolize, also separate the interpreter from that,

\footnotetext{
${ }^{269}$ Thomas Aquinas, Summa Theologiae I-II, q. 28, a. 5, trans. Fathers of the English Dominican Province (New York: Benzinger Bros., 1948).

${ }^{270}$ Nancy M. Martin and Joseph Runzo, "Love," 316.

271 Shneur Zalman of Lyady, "Iggeret haKodesh," in The Jewish Mystical Tradition, trans. Ben Zion Bokser (New York: Pilgrim Press, 1993), 218.

${ }^{272}$ Shneur Zalman of Lyady, "Iggeret haKodesh," in The Jewish Mystical Tradition, trans. Ben Zion Bokser, 218.
} 
given the radical difference between the finite symbol and the infinite symbolized. As Neville writes, God is not "really a person like an old wise enthroned king, nor like a lusty mother, not a disembodied spirit with a voice like the Cheshire cat's smile."273 Our symbols, whether particular and concrete like a statue of Durga and the narrative of the Exodus or abstract like God and Emptiness, are creatures of creatures not Lords of Lords. However, interpreters of religious symbols are not always conscious of this brokeness. If I naïvely took the divine to be the imposing statue of Durga before me, joy might be an expected response. But this joy might give way to longing as I become aware of the broken nature of the symbol. But even for a devotee who is not so naïve, the dialectic of engagement and separation in the use of devotional symbols produces an oscillation between longing and joy.

We can detect a similar pattern of hope and despair in the Psalms, which may be due to symbols particular to the Jewish tradition. Commenting on the Adam and Eve banishment narrative, Stephen Prothero writes that "it sets into motion the two great contrapuntal themes in the Jewish story: a rhythm of wrongdoing, punishment, and exile; and a rhythm of covenant, breach, and new covenant." ${ }^{, 274}$ The recurring symbols of exile (from God, from Zion, from one another, etc.) and covenantal promise produce patters of despair and hope. The Psalmist writes, "As a deer longs for flowing streams, so my soul longs for you, O God. My soul thirsts for God, for the living God. When shall I come and behold the face of God?"275 While the language is of longing, the last question assumes the possibility of encountering God and the images of search and thirsting

\footnotetext{
${ }^{273}$ Robert C. Neville, The Truth of Broken Symbols (Albany: State University of New York Press, 1996), xi.

${ }^{274}$ Stephen Prothero, God Is Not One: The Eight Rival Religions That Run World-and Why Their Differences Matter (New York: HarperOne, 2010), 243.

${ }^{275}$ Psalm 42:1-2, NRSV.
} 
illustrate the arduous nature of reaching this end. Here the Psalmist places hope in the promise of God. But the Psalmist also offers beautiful pictures of despair: "By the rivers of Babylon - there we sat down and there we wept when we remembered Zion. On the willows there we hung up our harps. For there our captors asked us for songs, and our tormentors asked for mirth, saying, "Sing us one of the songs of Zion." ${ }^{, 276}$ Of course, this is also an expression for sorrow, for the absence of Zion is apprehended as evil. But insofar as the object is Zion (a symbol of the covenant), rather than the absence of it, it is religious despair. Of course, this despair is not permanent. God restores hope through the pattern of covenant, breach, new covenant. In a term borrowed from John Hick, this renewal of hope makes Judaism, along with the other major world religions, cosmically optimistic. $^{277}$

\section{Islam}

In Orthodox Islam, the Qur'an and the Hadith emphasize God's love for creation. The Fatihah, a prayer to God which opens the Qur'an and is referred to as the very essence of the Qur'an, emphasizes the loving mercy of God: "In the Name of God, the merciful Lord of mercy. Praise be to God, the Lord of all being, The merciful Lord of mercy., ${ }^{278}$ The emphasis on God's love of creation over human love for God in the Qur'an is a consequent of its form. Whereas the Hebrew Bible contains multiple genres including narratives, history, and poetry, all of which lend themselves to expressions of human love for the divine, the Qur'an, with the one exception of the Fatihah, is written in

\footnotetext{
${ }^{276}$ Psalm 137:1-4, NRSV.

277 John Hick, "The Religious Meaning of Life," in The Meaning of Life in the World Religions, ed. Joseph Runzo and Nancy M. Martin (Oxford: Oneworld Publications, 2000), 274.

${ }^{278}$ Koran 1:1, trans. N. J. Dawood (New York: Penguin, 1990), 84.
} 
the form of direct divine speech. However, through this direct divine speech comes striking, concrete images which serve as symbols of ultimacy. Detailed descriptions of paradise, for instance, illicit passionate responses of longing. Such images of paradise include soft couches, pomegranate trees, virgins, fine carpets, silk robes, temperate climates, silver goblets with ginger flavored water served by boys graced with eternal youth. The Qur'an promises that "when you gaze upon that scene, you will behold a kingdom blissful and glorious." 279

Neville remarks on the need for such concrete images in a devotional, as opposed to a theological, context Abstract concepts at the level of theological thought are likely to be inefficacious in terms of spiritual transformation. For the sake of spiritual transformation, symbols on the devotional levels are embellished, complex, and interwoven in a way that they are not at the theological level and its goal of communicability. ${ }^{280}$ Particular and imagistic symbols in religion are needed in order to engage individuals on an emotional level, and thus to be able to direct one's love, longing, and joy toward the religious object. And this is true for devotees at various levels of spiritual maturity, including those who can intellectually grasp abstract symbols. It is often assumed that particularistic imagery is associated with earlier stages of spiritual development. However, there is often profound depth in particularistic imagery that is only grasped by more religiously adept individuals. As Neville observes, "The issue is not so much what symbols are appropriate at each stage, but how symbols are appropriated. ${ }^{281}$ However, as we saw with Judaism, concrete symbolism, while necessary, is not without its dangers. The symbol itself can become the object of ultimate

\footnotetext{
${ }^{279}$ Koran 76:15, trans. N. J. Dawood (New York: Penguin, 1990), 578.

${ }^{280}$ Robert C. Neville, The Truth of Broken Symbols, 152.

${ }^{281}$ Robert C. Neville, The Truth of Broken Symbols, 170.
} 
concern. This danger led 8th century Islamic mystic Rabi'a Al-Adawiyyah of Basra to run through the streets with a torch in one hand and a bucket of water in the other. She aimed to pour water on the flames of hell and to torch paradise so that no one might mistakenly follow Islam out of fear of punishment or hope of reward, but simply for the sake of God. Interestingly, her own symbols of bucket and torch were as striking as those she needed to destroy, thus testifying to the need of such symbols. If the Thomistic understanding of religious emotions is correct, imagistic symbols are necessary if part of the transformative goal of a religious tradition is to transform passionate desires into love of the divine. As Miner writes, "Amor sensitivus cannot be neglected by the rational creature in its motion toward God. . . Lacking the energy of the sensitive appetite, the amor intellectualis Dei will be weak."

In Islam, transforming one's desires into the love of God is particularly pronounced in the mystical Sufi tradition where poetry is filled with themes of transformative love, longing, and joy. Rabi'a, for example, asks her readers to imagine God as an erotic lover. "The doors of kings are locked and guarded by their henchmen, but your door is open to those who call upon you. My Lord, each lover is now alone with his beloved. And I am alone with you." ${ }^{283}$ The 13th century mystic Jelaluddin Rumi emphasizes that the longing of separation is a necessary corollary of love for the divine. His parable "Completely Cooked" illustrates this emphasis:

A certain person came to the Friend's door and knocked. "Who's there?" "It's Me." The Friend answered, "Go away. There's no place for raw meat at this table." The individual went wandering for a year. Nothing but the thirst of separation can change hypocrisy and ego. The person returned completely cooked, walked up and down in front of the Friend's house, gently

\footnotetext{
282 Thomas Miner, Thomas Aquinas on the Passions, 122.

${ }^{283}$ Huston Smith, The World's Religions: Our Great Wisdom Traditions (San Francisco: HarperCollins, 1991), 260.
} 
knocked. "Who is it?" "You." "Please come in, my Self. There's no place in this house for two." 284

For Rumi, the transformative process of deification and the Sufi goal of union with God only occurs through the erosion of ego via longing and separation. The symbol of the self as raw meat in need of transformation and the symbol of wandering in separation elicit the very longing prescribed. But Rumi presents the journey of transformative love not only as a one of longing, but also as one of joy. "Come, come, whoever you are, Wanderer, worshiper, lover of leaving, it doesn't matter. Ours is a caravan of endless joy. Even if you've broken your vows a hundred times - Come, come, yet again come!"285 In this final line, Rumi directs the reader away from despair to hope. The soteriological end is difficult, as the hundred broken vows suggest. But Rumi's hope is rooted in his awareness that the agency of pursuit is not only at the human end. In a particular hadith, God says, "if [my servant] draws nearer to Me by handsbreadth, I draw nearer to Him by an armslength; and if he draws nearer to Me by an armslength, I draw nearer to him by a fathom; and if he comes to me walking, I come to him running."286 This symbol of God's agency, as in Judaism, restores hope of union and produces gratitude toward God.

\section{Bhakti Hinduism}

The cultivation of religious love in Hinduism is most visible in the bhakti tradition. According to this tradition, June McDaniel observes that "emotion is the path

\footnotetext{
284 Jelaluddin Rumi, “Completely Cooked," in The World's Wisdom: Sacred Texts of the World's Religions, ed. Philip Novak (New York: HarperOne, 1994), 326-7.

285 Jelaluddin Rumi, “The Caravan of Joy," in The World's Wisdom: Sacred Texts of the World's Religions, ed. Philip Novak (New York: HarperOne, 1994), 328.

${ }^{286}$ Philip Novak, ed., The World's Wisdom: Sacred Texts of the World's Religions (New York: HarperOne, 1994), 313.
} 
to God and is thus sacred. Rather than trying to eliminate emotion, the goal is to intensify emotion until it becomes powerful, over-whelming, the center of the devotee's being. ... Human emotion is transformed into divine emotion; it is boiled, thickened, purified, and redirected." ${ }^{287}$ In order to achieve this thickening and purification, the bhakti tradition symbolizes the divine in various relationships to the devotee in order to direct all forms of human love toward the divine. In the bhakti tradition, the devotee attempts to develop an multifaceted relationship with the divine. The devotee is brought into contact with the divine through various types of love relationships and through every form of sensation. ${ }^{288}$ For example the god Krishna is iconically depicted as a child, as a friend, and as an erotic lover. The North Indian Vishnu saint Surdas speaks of taking on the persona of Yashoda, the adoptive mother of Krishna, in order to direct parental love to the divine. ${ }^{289}$ Readers of the Bhagavad-Gita are offered a depiction of the divine Krishna as a trusted advisor and friend. The Bhagavata Purana paints Krishna as the object of loving adoration by the gopi girls. The use of multiple relational symbols serves to direct the devotee's entire love toward the divine. But as we saw in Judaism and Islam, a dialectical tension between love's longing and love's joy persists. Nancy Martin remarks, "From a devotional point of view, we are fundamentally lovers of God, and our life is a journey of ever-deepening love, marked also by intensified longing. Separation between self and God is absolutely essential for love and relationality to be possible, but it leaves us pining for complete union." 290

\footnotetext{
287 June McDaniel, "Emotion in Bengali Religious Thought," in Religion and Emotion: Approaches and Interpretations, ed. John Corrigan (New York: Oxford University Press, 2004), 259-60.

${ }^{288}$ Nancy M. Martin, "Love and Longing in Hinduism," in The Meaning of Life in the World's Religions, ed. Joseph Runzo and Nancy M. Martin (Boston: Oneworld Publications, 2000), 205.

${ }^{289}$ Nancy M. Martin and Joseph Runzo, "Love," 323.

${ }^{290}$ Nancy M. Martin, "Love and Longing in Hinduism," 212.
} 


\section{Mahayana Buddhism}

Thus far, I have considered emotions in the religious life of traditions that emphasize ultimacy as a transcendent (even if also immanent) ontological reality. However, the category of ultimacy itself proves difficult with many forms of Buddhism. As Malcolm David Eckel notes, “[Madhyamika Buddhists] are not out to uncover a secure and stable reality behind the changeable world of appearances; they want to demonstrate that there is no stable, ultimate reality." ${ }^{, 291}$ So, perhaps we could understand the Buddhist conception of ultimacy in terms of Emptiness. But according to Eckel, it is not Emptiness that is ultimate in Buddhism, but the awareness of Emptiness: "The Madhyamikas took the word ultimate (paramartha) as having a double reference: it could refer to the nature of reality (to Emptiness as the object of cognition) or to a person's awareness of the nature of reality. Of these two possible meanings, the second was considered the more important." ${ }^{, 292}$ From this perspective, it is the awareness of Emptiness (nirvana) that is ultimate in Buddhism. Thus, indexical religious symbols in Buddhism would be objects of sensory apprehension which point the subject toward this awareness. This could include a wide range of objects including stories of the Buddha, mandalas and other meditative aids, statues of the Buddha, stupas, and, as we will see, other sentient beings.

\footnotetext{
${ }^{291}$ Malcolm David Eckel with John J, Thatamanil, "Cooking the Last Fruit of Nihilism: Buddhist Approaches to Ultimate Reality," in Ultimate Realities, ed. Robert Cummings Neville (Albany, State University of New York Press, 2001), 127.

292 Malcolm David Eckel with John J, Thatamanil, "Cooking the Last Fruit of Nihilism: Buddhist Approaches to Ultimate Reality," in Ultimate Realities, ed. Robert Cummings Neville (Albany, State University of New York Press, 2001), 130.
} 
The clearest expression of the model of the saint in Mahayana Buddhism is the bodhisattva. The bodhisattva is one who has attained enlightenment, but out of compassion finds it appropriate to remain in the world of duality and illusion in order to assist all sentient beings toward the same goal of ending suffering through wisdom. Thus, on one level the bodhisattva can be considered an indexical symbol as some bodhisattvas, most notably Guanyin and Amida Buddha, serve as objects of devotion. But the bodhisattva is also the ideal end of Mahayana Buddhist transformation. The necessary corollary of the awareness of Emptiness (wisdom) is compassion. As Martin and Runzo note, "compassion complemented by wisdom forms the heart of the Buddhist path." 293 The transformation toward the ideal saint in Buddhism involves not simply the cultivation of compassion, but the cultivation of sympathetic joy. The following is a description of a priest of a Lotus Sect who was posthumously recognized as a bodhisattva: "He chanted the Lotus Sutra day and night. He had no fixed home but drifted from place to place. His heart was full of compassion; when he witnessed another's suffering, he felt it as his suffering, and when he witnessed another's joy, he felt it as his own happiness." 294

It is clear from this description that friendship love is a necessary precondition for the bodhisattva's compassion and joy. It is not a disinterested love, for it is in the interest of the bodhisattva to do what she can to eliminate the suffering of others. But it is a love for the sake of the other. It is the union of interests that make sympathetic joy and the longing of compassion possible, for the bodhisattvas feel the joy and suffering of others as their own. But one might ask why the sympathetic joy or the compassionate longing

\footnotetext{
${ }^{293}$ Nancy M. Martin and Joseph Runzo, "Love,” 311.

${ }^{294}$ Marian Ury, trans., Tales of Times Now Past: Sixty-Two Stories form a Medieval Japanese Collection (Berkeley: University of California Press, 1979), 90.
} 
of the Bodhisattva should count as a religious emotion on my framework. Is the emotion's object, the good of other sentient beings, a religious symbol of ultimacy? Malcolm Eckel describes a lecture the Dalai Lama gave at Harvard on the Buddhist concept of the self. Eckel writes that "He began speaking in English about the importance of compassion. If you want to know who you are, he said, learn to be compassionate toward your neighbor." ${ }^{295}$ The Dalai Lama then proceeded to give a more esoteric lecture on Emptiness in Tibetan. But the point here is that focusing on others, presumably both in the sufferings and joys, can point, attune, and conform the Buddhist toward what is ultimate - the awareness of the 'no-self' which just is the awareness of Emptiness. Or, as John Hick puts it, "liberation from $[d u k k h a]$ is achieved by transcending the ego point of view in order to participate in a more universal perspective. ${ }^{296}$ By transcending their ego and focusing on others, the bodhisattva opens herself to the religious oscillations of compassionate longing and sympathetic joy.

\section{Conclusion}

While I have focused here on using the Thomistic framework to identify common emotional patterns, I hope the reader can also glean other ways in which the framework could be put to use. For example, by analyzing expressions of religious emotions, the religious scholars can spot incongruences between the normative, orthodox meaning of some symbol and the way the symbol is interpreted by ordinary devotees. It can also help in the study of the history of symbolic meaning by tracing changes in emotional

\footnotetext{
295 Malcolm David Eckel with John J, Thatamanil, "Cooking the Last Fruit of Nihilism: Buddhist Approaches to Ultimate Reality," in Ultimate Realities, ed. Robert Cummings Neville (Albany, State University of New York Press, 2001), 130.

${ }^{296}$ John Hick, "The Religious Meaning of Life," in The Meaning of Life in the World Religions, ed. Joseph Runzo and Nancy M. Martin (Oxford: Oneworld Publications, 2000), 282.
} 
response to the same symbol or motif. But I hope what I have done, by focusing on emotional patterns across religious traditions, at least illustrates how the theory of religious emotions can begin to frame the rich subtlety of emotional experience in the religious life. 


\section{CHAPTER FOUR}

\section{AN ANALYSIS OF RELIGIOUS EMOTIONS OF REPULSION}

\section{Introduction}

In chapter three, I offered an analysis of the religious emotions of attractionparticularly love, longing, joy, hope, and despair. In this chapter, I will offer an analysis of the religious emotions of repulsion. For Aquinas, these passions include hate, aversion, sorrow, fear, daring, and anger. While this completes Aquinas's list of the eleven basic passions, we must remember that this framework allows for the analysis of other emotional states. For example, last chapter we saw that wonder can be analyzed either as a type of longing, a type of joy, or both. Similarly, compassion includes both an element of sorrow and an element of longing. So the Thomistic theory is able to handle more than the eleven basic passions by further specifying the object of the passion or the narrative context in which the passion occurs.

In chapter three, I was interested in illustrating how the model of religious emotions could be used to illustrate common emotional patterns in the devotional and spiritual life across religious traditions. This required me to begin by covering the generic forms of the all the basic passions of attraction before illustrating the religious patterns. In this chapter, I will continue to operate from a definition of religion as a set of interrelated and traditional human practices performed in response to perceived ultimacy with the end of individual, social, and/or global transformation. I will also again focus on 
Neville's model of the saint to explore how religious traditions use religious symbols to transform the sensitive appetite to better conform to perceived ultimacy. However, my objective in this chapter is not to show how the Thomistic framework can be used to trace common patterns of religious emotional experience, but to illustrate how it can be used to illuminate the diversity of saintly ideals both across and within religious traditions. Given the focus is not on emotional patterns, but the role each emotion plays in the devotional life, I will not need to cover all the generic emotions first. Instead, I will begin by offering an analysis of Aquinas's account of hatred and then explore some of the various roles this emotion plays in the religious life. This pattern will continue for the remaining five passions of repulsion before concluding with some general reflections. My hope is that by highlighting the potential for the framework to shed light on nuanced differences in various saintly ideals (in addition to its ability to bring to light common emotional patterns), I will further illustrate the frameworks promise in comparative religion projects.

\section{The Passion of Hatred}

For Aquinas, hatred is the dissonance of the sensitive appetite with that which is apprehended as unsuitable in some way (repugnant, harmful, dangerous, etc.). In this sense, it is the contrary of love. As love is the harmony of the appetite with that which is perceived as good, so hatred is the dissonance with what is perceived as evil. ${ }^{297}$ As love is the principle of movement toward that which is perceived as suitable, so hate is the principle of movement away from that which is perceived as harmful in some way. It is a

\footnotetext{
${ }^{297}$ Thomas Aquinas, Summa Theologiae I-II, q. 29, a. 1, trans. Fathers of the English Dominican Province (New York: Benzinger Bros., 1948).
} 
principle that we mist presuppose of we are to account for other motions of aversion in relation to what is perceived as evil or bad in some way. ${ }^{298}$ While hatred might often lead toward aversion, fear, anger, or sorrow (and perhaps occur simultaneously with these emotions), it must be distinguished from other negative passions. Diana Fritz Cates explains that for Aquinas, hatred is "the simple act of being pained at the apprehension that one stands (in a particular respect) in relation to an object that is poised to actualize (more of) its potential at one's expense - and one is thus poised to be (further) hurt."299

As in the case of love, Aquinas distinguishes hate as a passion from the analogous usages of the term in relation to the natural and intellective appetite. Just as plants are naturally attuned and adapted toward that which is suitable such that we can analogously say, 'The plant loves the sun,' so things are naturally averse toward that which is harmful such that we can say, 'The plant hates this excessive heat.' But hate as a passion belongs to the sensitive appetite and is the natural inclination away from what is sensorily apprehended as harmful. It follows from this analysis that the concept of hatred, by itself, does not necessarily have a negative moral connotation. Every sensible being is vulnerable in relation to certain objects or situations, and hate, in its simplest form, in just the initial dissonance of the appetite with that which is perceived to impinge on one's well-being. This very general definition of hatred allows Aquinas to capture a wide variety of our usages of the term. When we think of hatred, the immoral and irrational forms of racism and sexism may spring to mind, but, as Cates observes, we might also "speak of hating the conditions that lead to the rampant sexual abuse of

\footnotetext{
${ }^{298}$ Diana Fritz Cates, Aquinas on the Emotions: A Religious-Ethical Inquiry (Washington, D.C.: Georgetown University Press, 2009), 145.

299 Diana Fritz Cates, Aquinas on the Emotions: A Religious-Ethical Inquiry (Washington, D.C.: Georgetown University Press, 2009), 145.
} 
women and girls around the world. On a lighter note, we might speak of hating rush-hour traffic, certain forms of music, mosquitoes, or the cold of winter." 300

Aquinas also distinguishes the passion of hate from purely intellectual hate.

Aquinas continues to draw on his distinction between the passions and the non-passionate affections to argue that as a sensitive passion, hatred cannot be directed at universal concepts "because the universal is obtained by abstraction from individual matter, on which every sensitive power is based."301 It is only by an analogous use of the term that the prophet hates injustice as such. However, Aquinas also notes there is another sense in which the passion of hate can be and often is directed toward the universal. ${ }^{302}$ "Hatred in the sensitive faculty can regard something universally: because this thing, by reason of its common nature, and not merely as an individual, is hostile to the animal—for instance, a wolf in regard to a sheep. Hence a sheep hates the wolf universally. ${ }^{, 303}$ Of course the sheep cannot apprehend the universal. Rather, it is qualities in common to all wolves that activate the passion of hatred in the sheep. Aquinas is more concerned with human emotions, and he makes this observation to help distinguish hate from anger. "On the other hand, anger is always caused by something in particular: because it is caused by some action of the one that hurts us; and actions proceed from individuals." As we shall see, one aspect of the object of anger for Aquinas is some perceived slight. Thus anger is always anger at some particular action by some particular person. But hatred often arises

\footnotetext{
300 Joel Gereboff, Keith Green, Diana Fritz Cates, and Maria Heim, "The Nature of the Beast: Hatred in Cross-Traditional Religious and Philosophical Perspective," Journal of the Society of Christian Ethics 29 (2009): 186.

${ }^{301}$ Thomas Aquinas, Summa Theologiae I-II, q. 29, a. 6, trans. Fathers of the English Dominican Province (New York: Benzinger Bros., 1948).

302 Thomas Aquinas, Summa Theologiae I-II, q. 29, a. 6, trans. Fathers of the English Dominican Province (New York: Benzinger Bros., 1948).

${ }^{303}$ Thomas Aquinas, Summa Theologiae I-II, q. 29, a. 1, trans. Fathers of the English Dominican Province (New York: Benzinger Bros., 1948).
} 
in response to the type of person/thing one is, rather than some particular action. As Robert Roberts remarks, "unlike anger, hatred does not necessarily construe its object in terms of some culpable offense. The only 'reason' for the evil look of the hated object may be that it is the object that it is." ${ }^{\text {304 }}$ Likewise, Keith Green explains, "Precisely because whole classes of objects and persons can have a consistent relationship to specific wants and interests, hatred, ... may have whole classes or general kinds as its object." ${ }^{305}$ My hatred for celebrity reality television shows in general is not directed at some perceived injustice. They simply get on my nerves in virtue of being the type of show they are. Or, in more Thomistic language, my sensitive appetite is in dissonance with such programing. Aaron Ben-ze'ev, in his discussion on hate and anger, also notices the tendency in hate to be directed toward universals: "Hate is often directed at different groups regardless of the personal differences between their individuals.”306 But both Aquinas and Ben-ze'ev also recognize that the object of hate must have some degree of specificity in order to account for its emotional intensity. ${ }^{307}$ Thus, the universal as such cannot be the object of passionate hatred, but the universal as instantiated in the particular can be.

While the object of hate is some perceived evil, Aquinas also argues that hate, like all other passions, is rooted and grounded in love. Aquinas writes that "a thing disagrees with another, through destroying or hindering that which agrees with it. Consequently . .

\footnotetext{
${ }^{304}$ Robert Roberts, Emotions: An Essay in the Aid of Moral Psychology (Cambridge: Cambridge University Press, 2003), 250.

${ }^{305}$ Keith Green, "Aquinas on Attachment, Envy, and Hatred in the Summa Theologica," Journal of Religious Ethics 35 (2007): 412

306 Aaron Ben-ze-ev, The Subtlety of Emotions (Cambridge: Massachusetts Institute of Technology), 384.

307 See Aaron Ben-ze-ev, The Subtlety of Emotions (Cambridge: Massachusetts Institute of Technology), 381 .
} 
. nothing is hated, save through being contrary of a suitable thing which is loved." ${ }^{, 308}$ In the last chapter we saw that love both gives rise to and persists in longing and joy such that love is both a cause and a necessary condition of longing and joy. Likewise, Aquinas claims love is a cause and a necessary condition of hate. My love for one object disposes me to hate some other object that threatens the beloved. Keith Green summarizes Aquinas's principles on the relationship between love and hate as follows: "For any rational creature: If one loves $\mathrm{A}$, then one is thereby predisposed . . . to hate whatever impedes obtaining or harms A."309 But in claiming that love persists in hate, Aquinas does not mean that I experience love when I experience hate. The relationship is logical rather than phenomenological. As Aquinas states, "Now love and hatred are naturally simultaneous, logically but not really.",310

\section{Religious Hatred}

When one hears the term 'religious hatred,' perhaps what immediately comes to mind is the long history of hate-filled violence promoted by religious ideologies and institutions. Whether such instances should be included in the category of religious emotions as psychosomatic forms of concern toward devotional religious symbols is an interesting one. Certainly people can be profoundly mistaken in their perception of ultimacy such that the conformity of concern to this misunderstanding may lead to horrific violence. Robert Neville remarks that "a small mistake in saintly reasoning can

\footnotetext{
308 Thomas Aquinas, Summa Theologiae I-II, q. 29, a. 2, trans. Fathers of the English Dominican Province (New York: Benzinger Bros., 1948).

${ }^{309}$ Keith Green, "Aquinas on Attachment, Envy, and Hatred in the Summa Theologica," Journal of Religious Ethics 35 (2007): 414

310 Thomas Aquinas, Summa Theologiae I-II, q. 29, a. 2, trans. Fathers of the English Dominican Province (New York: Benzinger Bros., 1948).
} 
unleash a mighty power for harm. If a misdirected solider is dangerous, a mistaken saint is close to Satan!"311 However, we must remember the broadness of Aquinas's understanding of hatred. Given this account, Aquinas's does not advocate an a priori rejection of hatred in all its forms. Whether a particular instance of hatred is healthy depends upon the open question of what is, in fact, good for human beings both individually and collectively. ${ }^{312}$ My hatred for celebrity reality television shows is only irrational or immoral if watching such programing is a necessary constituent of the good life. If watching such programming is counter to the conduciveness of human flourishing, such hatred should be consented to and perhaps even cultivated. Similarly, religious traditions which offer a vision of the fully realized saint, junzi, or mensch may advocate hatred of that which is perceived to run counter to the spiritual quest. Luke's Jesus informs the crowd that discipleship requires a hatred toward the attachments of family and even life itself. ${ }^{313}$ The apostle Paul commands his readers to hate sin and what is evil. ${ }^{314}$ In his Religious Affections, Jonathan Edwards lists hatred and abhorrence of sin as a necessary corollary of the love of God. ${ }^{315}$ The writer of Ecclesiastes speaks of a time to love and a time to hate. ${ }^{316}$ In the Bhagavad Gita, Arjuna declares his hatred for triumph, domination, wealth, and ease. ${ }^{317}$ Thus, the object of religious hatred is whatever is perceived as unsuitable to proper conformity with perceived ultimacy. As a

\footnotetext{
${ }^{311}$ Robert C. Neville, Solider, Sage, Saint (New York: Fordham University Press, 1978), 89.

${ }^{312}$ See Joel Gereboff, Keith Green, Diana Fritz Cates, and Maria Heim, "The Nature of the Beast: Hatred in Cross-Traditional Religious and Philosophical Perspective," Journal of the Society of Christian Ethics 29 (2009): 191.

${ }^{313}$ Luke 14:25-6, NRSV

314 Romans 12:9, NRSV.

315 Jonathan Edwards, The Religious Affections in Three Parts (Grand Rapids, Michigan: Sovereign Grace Publishers, 1971), 33.

${ }^{316}$ Ecclesiastes 3:8, NRSV.

${ }^{317}$ Philip Novak, ed., "The Bhagavad Gita," in The World's Wisdom (New York: HaperCollins Publishers, 1994), 24.
} 
result, the objects of sin, wealth, power, etc. serve as indexical symbols comporting the heart of the devoted to what is of highest value. But we can distinguish religious hate from other religious emotions of repulsion. I may feel guilty about some particular sin I have committed, but guilt is a form of sorrow at some particular evil action that has already been committed. But I may hate adultery only because I see it as potentially harmful toward achieving some spiritual ideal.

However, the notion of a virtuous hatred is foreign to certain saintly ideals. In her discussion of the saintly arhat in Therevada Buddhism, Maria Heim notes that the great thinker "Buddhaghosa finds no value whatsoever in hatred: There are no instances of righteous or legitimate hatred or anger in these sources." 318 Hatred in this tradition is included with greed and delusion as the root of all pain and suffering. Accordingly, the conformity of the heart in response to perceived ultimacy would involve eliminating all forms of hate. Buddhaghosa advises a number of practices to help one achieve this transformation. First, there are meditative techniques designed to break down the barrier between self and other. According to Heim, this practice begins by generating lovingkindness toward oneself. Once this is achieved, one begins to extend such feelings to friends, then to neutrals, and eventually even to enemies. ${ }^{319}$ Here, the thoughts of self, friends, neutrals, and enemies serve as indexical symbols connecting and attuning the interpreters with the ultimacy of enlightenment. In other practices, stories of the Buddha serve as devotional symbols for similar purposes. "One may take inspiration from the

\footnotetext{
${ }^{318}$ Joel Gereboff, Keith Green, Diana Fritz Cates, and Maria Heim, "The Nature of the Beast: Hatred in Cross-Traditional Religious and Philosophical Perspective," Journal of the Society of Christian Ethics 29 (2009): 193-4.

${ }^{319}$ Joel Gereboff, Keith Green, Diana Fritz Cates, and Maria Heim, "The Nature of the Beast: Hatred in Cross-Traditional Religious and Philosophical Perspective," Journal of the Society of Christian Ethics 29 (2009): 194.
} 
previous lives of the Buddha when he was a Bodhisattva and practiced forbearance, such as the story of when he was torn limb by limb by a king and did not feel the slightest anger." ${ }^{320}$ Other practices include using the concept of samsara, the wheel of rebirth, to alter one's construal of the object of hatred. Given that we have lived innumerable lives, we have all been in various relationships with others such that it is quite possible that the object of hatred had once been the subject's mother. Thus one should construe the object of hate as someone who has "carried me in her womb for ten months and removed from me without disgust, as if it were yellow sandalwood, my urine, excrement, spittle, snot, etc., and played with me, nourished me, carrying me about on her hip." ${ }^{321}$ This is a vivid example of the way abstract concepts, such as samsara, can, through the imagination, shape our sensory apprehension of others such that they serve as indexical symbols attuning the subject with perceived ultimacy.

\section{The Passion of Aversion}

Aversion is the only basic passion that Aquinas does not address specifically in questions 26-48 when he addresses the particular passions. Rather, Aquinas simply notes the structure of aversion in his account of the passions generally. Here, he speaks of aversion as the contrary of desire: "If the good be not yet possessed, it causes in the appetite a movement towards the attainment of the good beloved: and this belongs to the passion of desire or concupiscence: and contrary to it, in respect of evil, is the passion of

\footnotetext{
${ }^{320}$ Joel Gereboff, Keith Green, Diana Fritz Cates, and Maria Heim, “The Nature of the Beast: Hatred in Cross-Traditional Religious and Philosophical Perspective," Journal of the Society of Christian Ethics 29 (2009): 194.

${ }^{321}$ Bhadantácariya Buddhaghosa, The Path of Purification, trans. Bhikku Náóamoli (Kandy, Sri Lanka: Buddhist Publication Society), 300.
} 
aversion." ${ }^{322}$ Given that aversion is the contrary of desire, we can glean Aquinas's understanding of aversion from his account of longing. Just as longing was a craving for some type of union with some particular object which is apprehended as good in some way (pleasant, suitable, etc.), so aversion is an appetitible movement away from some particular which is perceived as bad in some way (painful, unsuitable, etc.). Aquinas further defines aversion by contrasting it with fear. The distinction between aversion and fear is rooted in a broader distinction between the concupiscible and irascible appetitible powers. Aquinas writes that "the object of the concupiscible power is sensible good or evil, simply apprehended as such, which causes pleasure or pain. But, since the soul must, of necessity, experience difficulty or struggle at times, in acquiring some such good, or avoiding some such evil, ... this very good or evil, inasmuch as is of an arduous or difficult nature, is the object of the irascible faculty.",323 While fear is also an appetitive movement away from that which is perceived as bad in some way, the object of fear is perceived as difficult to avoid, which is not the case with simple aversion. Thus we might classify forms of disgust or repugnance as forms of aversion rather than fear. Finally, given its parallel structure to longing, we can make a distinction between natural and non-natural aversion much as Aquinas made explicit in the context of longing. The object of natural aversion is an object which is naturally unsuitable due to the biology of the organism (the disgust of rotten food, perhaps), while the object of non-natural aversion is something which is understood (correctly or incorrectly) to be evil or unsuitable (such as sexual taboos).

\footnotetext{
322 Thomas Aquinas, Summa Theologiae I-II, q. 23, a. 4, trans. Fathers of the English Dominican Province (New York: Benzinger Bros., 1948).

${ }^{323}$ Thomas Aquinas, Summa Theologiae I-II, q. 23, a. 1, trans. Fathers of the English Dominican Province (New York: Benzinger Bros., 1948).
} 


\section{Religious Aversion}

The Theravada Buddhist practice of corpse meditation serves as a good example for an analysis of religious disgust. In The Path of Purification, Buddhaghosa outlines "foulness as a meditation subject" by listing ten forms of corpse meditation: the bloated, the livid, the festering, the cut up, the gnawed, the scattered, the hacked and scattered, the bleeding, the worm-infested, and the skeleton. ${ }^{324}$ Buddhaghosa offers rather detailed instruction on how meditation on these various types of corpses should occur in order to ensure safety and effectiveness. The immediate purpose of such meditation is to conquer various forms of bodily lust and desire. For example, meditation on the bloated is prescribed for those who are easily aroused by the shape of the body; the livid is for those who are aroused by skin color; the festering helps those who are aroused by perfume. ${ }^{325}$ But, according to Buddhaghosa, there are other benefits to deliberately inculcating disgust than just taming sexual desire. "And repulsive as this object is, still it arouses joy and happiness in him by his seeing its advantages thus, 'Surely in this way I shall be liberated for aging and death.",326 The point is not only to eliminate particular lusts and desires, but selfish desires in general which lie at the heart of the suffering needed to be overcome. Additionally, focus on the disgusting aspects of the body help to eliminate unjust social distinctions. After describing the entrails of the body in gory detail, Buddhaghosa concludes that in terms of the "universal repulsiveness of the body ... even

\footnotetext{
${ }^{324}$ Bhadantácariya Buddhaghosa, The Path of Purification, trans. Bhikku Náóamoli (Kandy, Sri Lanka: Buddhist Publication Society), 169-70.

${ }^{325}$ Bhadantácariya Buddhaghosa, The Path of Purification, trans. Bhikku Náóamoli (Kandy, Sri Lanka: Buddhist Publication Society), 182.

${ }^{326}$ Bhadantácariya Buddhaghosa, The Path of Purification, trans. Bhikku Náóamoli (Kandy, Sri Lanka: Buddhist Publication Society), 183.
} 
a king, if he wandered from village to village with his hair in its natural wild disorder, [is] no different from a flower-scavenger or an outcaste or what you will. So there is no distinction between a king's body and an outcaste's in so far as its impure stinking nauseating repulsiveness is concerned." ${ }^{327}$ Thus the benefits of such meditation is not simply transformation of individual desires, but social transformation as well.

There are also examples of prescriptions to deliberately inculcate disgust in the Jewish mystical tradition, although for quite different spiritual ends. Sixteenth century Palestinian Rabbi Elijah de Vidas wrote a Kabbalistic ethical treatise entitled Reshit Hochma (The Beginning of Wisdom), which is still widely studied by Orthodox Jews today. In this work, de Vidas identifies anger as a religious vice because it is rooted in a pride that is incompatible with submission to God. "Anger is a result of pride since if a person's heart was broken and crushed most certainly he would not become angered and would not respond to insult." ${ }^{, 328}$ De Vidas offers various methods to eliminate anger in order to better conform to the saintly ideal he envisions: "If an individual will be despised in his own eyes and will consider himself to be disgusting, he will not respond to his being shamed. The way in which to consider himself disgusting is to think about the defects and lowliness of his soul, such that he is disgusting in the eyes of the Creator by virtue of his evil deeds." ${ }^{329}$ Like Buddhaghosa, de Vidas prescribes a religious disgust as a means for transformation. In this example, the subject's sinful soul serves as the indexical symbol that initiates the transformation. Solomon Schimmel explains the offended subject is instructed construe the wrongs as but a tiny fraction of his or her own

\footnotetext{
${ }^{327}$ Bhadantácariya Buddhaghosa, The Path of Purification, trans. Bhikku Nááamoli (Kandy, Sri Lanka: Buddhist Publication Society), 183.

${ }^{328}$ de Vidas, Reshit Hochma (Poland: Beyozefof, 1868), 174.

${ }^{329}$ de Vidas, Reshit Hochma (Poland: Beyozefof, 1868), 177.
} 
sins against the divine realm, such the extent of his or her injury pails in comparison to the damage wrought by the subject. ${ }^{330}$ De Vidas encourages not only cultivation of moral disgust, but also bodily disgust. He exhorts his reader to "think about his vileness both in life and in death; while alive that his head is covered with worms and lice and in death man is a worm that is disgusting in virtue of its stench and the foul odor of his intestines." ${ }^{, 31}$ This imaginative exercise will reduce anger, for such a man "will say to himself 'does a rotten corpse respond to insult?' Surely he will not respond as it would be irrational to do so." ${ }^{332}$ While both Buddhaghosa and de Vidas advocate religious disgust as a means of transformation, they envision quite different religious ends. For de Vidas, the disgust is not advocated as a means to reduce the desire that is at the root of suffering, but to reduce the pride that is at the root of sin and rebellion against the Torah.

Additionally, for de Vidas, this elimination of pride and anger has eternal ramifications. Solomon explains that according to de Vidas, "just as in life, he, through his anger, cast out the Divine Presence from its natural terrestrial residence, the human soul, so upon his death, the Holy One, blessed be He, will prevent his soul's entry into the realm of the divine. ${ }^{333}$

\section{The Passion of Sorrow}

Of all the passions, Aquinas dedicates the most extended treatment to sorrow. $\mathrm{He}$ begins by distinguishing bodily pain from sorrow. According to Aquinas, pain (dolor), in

\footnotetext{
${ }^{330}$ Solomon Schimmel, "Education of the Emotions in Jewish Devotional Literature: Anger and Its Control," Journal of Religious Ethics 8 (Fall 1980): 262.

${ }^{331}$ de Vidas, Reshit Hochma (Poland: Beyozefof, 1868), 177.

332 de Vidas, Reshit Hochma (Poland: Beyozefof, 1868), 177.

${ }^{333}$ Solomon Schimmel, "Education of the Emotions in Jewish Devotional Literature: Anger and Its Control," Journal of Religious Ethics 8 (Fall 1980): 263.
} 
the broadest sense of the term, is a passion and sorrow (tristitia) is one form of pain. We do not typically think of pain as an emotion, as it is associated with the body rather than the mind. Likewise, Aquinas's objectors argue that pain is not a passion "because no passion of the soul is in the body. ${ }^{334}$ However, Aquinas argues that "we speak of the body, because the cause of pain is in the body... . But the movement of pain is always in the soul; since 'the body cannot feel pain unless the soul feels it.","335 Thus, for Aquinas, the consciousness of pain is a change in the sensitive appetite to some perceived present evil. However, Aquinas distinguishes physical pain from sorrow on the grounds that physical pain arises "from the apprehension of an exterior sense" while sorrow arises "from the interior apprehension of the intellect or of the imagination.,"336 For Thomas, the 'exterior senses' are the five senses of touch, taste, smell, hearing, and sight. Physical pain is the change in the sensitive appetite to evil perceived simply though the external senses. This would presumably include not just the pain of touch (for example a paper cut), but also noise irritation, blinding lights, bitter tastes, etc. Sorrow, on the other hand, involves a change in the sensitive appetite to evil perceived through the imagination, where imagination is understood in the broad sense as the ability to perceive objects or images and such objects and images may, for humans, be informed by the ideas of the intellect. $^{337}$

${ }^{334}$ Thomas Aquinas, Summa Theologiae I-II, q. 35, a. 1, trans. Fathers of the English Dominican Province (New York: Benzinger Bros., 1948).

${ }^{335}$ Thomas Aquinas, Summa Theologiae I-II, q. 35, a. 1, trans. Fathers of the English Dominican Province (New York: Benzinger Bros., 1948).

${ }^{336}$ Thomas Aquinas, Summa Theologiae I-II, q. 35, a. 2, trans. Fathers of the English Dominican Province (New York: Benzinger Bros., 1948).

${ }^{337}$ In this same article, Aquinas also makes a parallel distinction between pleasure and delight, where pleasure is a result of the apprehension purely from the exterior senses, while delight is a response to objects of the imagination. On Thomas Miner's reading, tristitia is a specifically human passion and is the counterpart to joy rather than delight. Accordingly, Aquinas's taxonomy involves dolor exterior (pain caused by any of the immediate proper senses), dolor interior (pain caused by the imagination, felt by 
The fact that objects of sorrow are images of the imagination explain how the objects of sorrow can include objects of memory and anticipation. Aquinas writes that the "external sense perceives only what is present; but the interior cognitive power can perceive the present, past and future. Consequently sorrow can regard present, past and future: whereas bodily pain, which follows apprehension of the external senses, can only regard something present." ${ }^{338}$ At first glance, this might seem at odds with Aquinas's placement of sorrow in relationship to aversion. Since aversion is distinguished from sorrow by the fact that, in aversion, the evil is not present while sorrow is identified as an appetitive response to some present evil, how can sorrow regard the future? Part of the answer has to do with the nature of the appetitive response. Aversion involves some sort of striving away from the absent evil, much as longing is a craving for the absent good. However, Aquinas describes the appetitive response of sorrow in terms of rest, as a kind of "violent repose." 339 Diane Fritz Cates explains that "sorrow is a cessation of the motion of withdrawing from and trying to avoid the unsuitable union.... Sorrow is, in other words, a motion of being-weighed-down, crushed, or 'depressed." ${ }^{340}$ So, sorrow occurs when the striving away (if the opportunity to strive away even presented itself in the first place) gives up, so to speak. For example, Aquinas classifies worry as a kind of

irrational as well as rational creatures), and tristitia (pain caused by rational apprehension, but involving a motion of the sensitive appetite). His rationale for limiting tristitia to human forms of sorrow is that Aquinas later (q. 35, a. 7) adopts the language of exterior and interior pain (rather than tristitia). According to Miner, "the implication is that dolor interior cannot be identified with tristitia." Thus, tristitia is a specifically human form of interior dolor. However, Aquinas, as far as I know, never explicitly limits tristitia to rational animals. But I do agree with Miner that there are, on Aquinas's account, specifically human forms of tristitia, which occur when reason is brought to bear on particulars. See Thomas Miner, Thomas Aquinas on the Passion (Cambridge, Cambridge University Press, 2009), 195-6.

${ }^{338}$ Thomas Aquinas, Summa Theologiae I-II, q. 35, a. 2, trans. Fathers of the English Dominican Province (New York: Benzinger Bros., 1948).

${ }^{339}$ Thomas Aquinas, Summa Theologiae I-II, q. 31, a. 8, trans. Fathers of the English Dominican Province (New York: Benzinger Bros., 1948).

${ }^{340}$ Diane Fritz Cates, Aquinas on the Emotions: A Religious-Ethical Inquiry (Washington D.C.: Georgetown University Press, 2009), 147. 
sorrow rather than a form of fear. Worry "weighs on the mind, so as to make escape seem impossible." ${ }^{341}$ Fear involves the apprehension that the evil object can be avoided. The central question in worry is not so much, "how can I avoid this evil?" but "what am I going to do given this evil will befall me?" Thus, there is a certain acceptance of the evil involved in sorrow, and in that sense the evil is present.

In his second question dedicated to sorrow, Aquinas considers whether it is better to understand the object of sorrow as a lack of good rather than a present evil, which leads naturally to a discussion of the relationship between longing and sorrow.

Regarding the first issue, Aquinas observes that while a lack of good is the cause of sorrow, the object of sorrow is a present evil. On Aquinas's metaphysics of value, evil simply is lack of good. Thus Aquinas writes that "if privations, as considered by the mind, were what they are in reality, this question would seem to be of no importance. . . But sorrow is a movement of the appetite in consequence of an apprehension: and even a privation, as apprehended, has the aspect of being. ${ }^{\text {342 }}$ Whether or not we agree with Aquinas's axiology, his observation is still important. The subject must apprehend the loss of good as an evil in order for sorrow to occur. For instance, to the extent that one sees their loss of employment as an opportunity for positive change, sorrow will be replaced by hope. Thus, while a cause of sorrow is necessarily a lack of good, the object of sorrow is a perceived present evil.

In addition to lack of good, Aquinas also identifies desire and longing as possible causes of sorrow. He explains that "whatever hinders a movement from reaching its end

\footnotetext{
${ }^{341}$ Thomas Aquinas, Summa Theologiae I-II, q. 35, a. 8, trans. Fathers of the English Dominican Province (New York: Benzinger Bros., 1948).

${ }^{342}$ Thomas Aquinas, Summa Theologiae I-II, q. 36, a. 1, trans. Fathers of the English Dominican Province (New York: Benzinger Bros., 1948).
} 
is contrary to that movement. Now that which is contrary to that movement of the appetite, is a cause of sorrow. Consequently, desire becomes a cause of sorrow, in so far as we sorrow for the delay of a desired good, or for its entire removal. ${ }^{\text {"343 }}$ Due to the fact that a couple desires children, they experience sorrow at the news of infertility. Because the athlete wants to win, she sorrows at the loss. But Aquinas also claims that desire is not a universal cause of sorrow, because we often sorrow more for the loss of an already possessed good than we do for not being able to obtain some good in the first place. ${ }^{344}$ For example, the parent's grief at the death of a child is greater than the sorrow resulting from the frustrated desire to have children. So while love and attachment is a universal cause of sorrow, desire is not.

Having considered both the causes and object of sorrow, Aquinas next considers the effects of sorrow. At first glance, it may appear that, given the effects of sorrow he concentrates on, Aquinas views the value of sorrow in a purely negative light. He argues that pain deprives one of the power to learn, that sorrow is a burden to the soul, that it weakens activity, and is the passion that is most harmful to the body. However, a closer reading suggests that sorrow, when rationally appropriate, is necessary for human flourishing. For example, Aquinas observes the obvious when he notes that acute pain draws the mind's attention to itself such that "man is prevented at the time from learning anything: indeed it can be so acute, that, as long as it lasts, a man is unable to give his attention even to that which he knew already., ${ }^{345}$ But Aquinas does not state that such an

\footnotetext{
${ }^{343}$ Thomas Aquinas, Summa Theologiae I-II, q. 36, a. 2, trans. Fathers of the English Dominican Province (New York: Benzinger Bros., 1948).

${ }^{344}$ Thomas Aquinas, Summa Theologiae I-II, q. 36, a. 2, trans. Fathers of the English Dominican Province (New York: Benzinger Bros., 1948).

${ }^{345}$ Thomas Aquinas, Summa Theologiae I-II, q. 37, a. 1, trans. Fathers of the English Dominican Province (New York: Benzinger Bros., 1948).
} 
effect is negative in the sense that it is not conducive to one's well-being. The ability to ignore my toothache in order to contemplate whether an a priori/synthetic proposition is possible might not be in my self-interest. Additionally, Aquinas claims that "moderate sorrow, that does not cause the mind to wander, can conduce to the acquisition of learning especially in regard to those things by which a man hopes to be freed from sorrow." "346 Aquinas recognizes that extreme depression often is counter to the flourishing of the subject. In this extreme form, "the soul, through being depressed so as to be unable to attend freely to outward things, withdraws to itself, closing itself up as it were." ${ }^{347}$ But in Aquinas's view, not all forms of sorrow are so debilitating, for "the uplifting of the soul ensues from the sorrow which is according to God." ${ }^{\text {,348 }}$

Aquinas addresses the value of sorrow more explicitly in the final question dedicated to the topic. He begins by distinguishing two ways in which an emotion can be considered to be good or evil. An emotion might be evil in the sense that no one would want to experience it. But the same emotion might be good in the sense that it is a sign of the subjects proper rejection of evil. ${ }^{349}$ For Aquinas, sorrow is evil in the sense that no one desires to be sorrowful or to be united with the evil that is a precondition to sorrow. But sorrow is a good in the sense that it can be a sign of virtuous character and can assist human flourishing and moral/spiritual maturity. It is good "inasmuch as it

\footnotetext{
${ }^{346}$ Thomas Aquinas, Summa Theologiae I-II, q. 37, a. 1, trans. Fathers of the English Dominican Province (New York: Benzinger Bros., 1948).

${ }^{347}$ Thomas Aquinas, Summa Theologiae I-II, q. 37, a. 2, trans. Fathers of the English Dominican Province (New York: Benzinger Bros., 1948).

348 Thomas Aquinas, Summa Theologiae I-II, q. 37, a. 2, trans. Fathers of the English Dominican Province (New York: Benzinger Bros., 1948).

${ }^{349}$ Thomas Aquinas, Summa Theologiae I-II, q. 39, a. 1, trans. Fathers of the English Dominican Province (New York: Benzinger Bros., 1948).
} 
denotes perception and rejection of evil." ${ }^{350}$ In fact, sorrow can be a virtue when the perception of evil is due to a right judgment of reason and the rejection of evil is rooted in the will. This should not be taken to mean that the virtue is passionless. Rather, "all the passions of the soul should be regulated according to the rule of reason, which is the root of the virtuous good."351 So for Aquinas, sorrow is not only useful for human survival and flourishing, but can also be constitutive of virtuous character. As we will now explore, sorrow often plays a central role in the transformation involved in the spiritual life.

\section{Religious Sorrow}

In his article on religious melancholy, Julius Rubin contrasts the role of sorrow in evangelical pietism and Christian mysticism. ${ }^{352}$ After noting the deep concern for the assurance of election in 17th and 18th century Calvinist pietism, Rubin remarks that the "spiritual itinerary from sin to salvation (ordo salutis) provided devotional exercises where the faithful would experience an initial godly sorrow for sin that progressed in severity by means of the 'inquisition of self-examination' into despair and the desired state of selfless ecstasy-holy desperation." ${ }^{, 353}$ The symbol of sin attunes and transforms the pietist to ultimacy by way of sorrow in the form of guilt. Such sorrow is saintly in

\footnotetext{
350 Thomas Aquinas, Summa Theologiae I-II, q. 39, a. 2, trans. Fathers of the English Dominican Province (New York: Benzinger Bros., 1948).

${ }^{351}$ Thomas Aquinas, Summa Theologiae I-II, q. 39, a. 2, trans. Fathers of the English Dominican Province (New York: Benzinger Bros., 1948).

352 Julius Rubin, "Melancholy," in The Oxford Handbook of Religion and Emotion, ed. John Corrigan (Oxford: Oxford University Press, 2008), 290-309.

353 Julius Rubin, "Melancholy," in The Oxford Handbook of Religion and Emotion, ed. John Corrigan (Oxford: Oxford University Press, 2008), 294.
} 
that it, in Aquinas's words, "denotes perception and rejection of evil." ${ }^{354}$ It allows the Calvinist to apprehend the total depravity of humanity and the sovereignty of God thus resulting in a holy desperation. Peter Iver Kaufman explains that "the pietists wanted to structure character and desire and took a special interest in the therapeutic value of despair."355 The value of guilt over one's sins, according to this evangelical pietism, is that it leads to despair in one's own power to transform the self, which, in turn, leaves room for the redemption and healing of Christ's work.

Drawing on Max Weber's distinction between "the active asceticism that is a God-willed action of the devout who are God's tools [Calvinism] with the contemplative possession of the holy as found in mysticism," 356 Rubin proceeds to contrast pietistic sorrow with Christian mystical sorrow. However, his initial description of mystical sorrow sounds similar to the pietistic sorrow analyzed above: "The mystic viewed the melancholy dark night as an indispensable spiritual exercise that was essential to wean the soul from worldliness and sin and prepare the soul for the ultimate and complete assimilation to God." 357 The role of sorrow in Christian mysticism is structurally similar to its role in pietism in that it is an essential step of preparation for the religious end. However, in pietism, sorrow results in the despair of one's will so that this will may be submitted to God's. In Rubin's language, the individual is a tool of God's will in pietism. However, in Christian mysticism, the sorrow of the dark night allows for an

\footnotetext{
${ }^{354}$ Thomas Aquinas, Summa Theologiae I-II, q. 39, a. 2, trans. Fathers of the English Dominican Province (New York: Benzinger Bros., 1948).

${ }^{355}$ Peter Ivan Kaufman, Prayer, Despair, and Drama: Elizabethan Introspection (Urbana, University of Illinois Press, 1996), 36.

${ }^{356}$ Julius Rubin, "Melancholy," in The Oxford Handbook of Religion and Emotion, ed. John Corrigan (Oxford: Oxford University Press, 2008), 297.

357 Julius Rubin, "Melancholy," in The Oxford Handbook of Religion and Emotion, ed. John Corrigan (Oxford: Oxford University Press, 2008), 298.
} 
experiential union with the divine. Here, "the individual is not a tool, but a vessel.,"358 Sorrow of worldliness and sin is thus a necessary prerequisite for the experience of God's love and the goal of the unitive life and deification.

In chapter three, I explored the Buddhist ideal of the bodhisattva primarily focusing on the compassionate longing/sympathetic joy dialect of this path. But the transformation of the Bodhisattva involves not only sympathetic joy (mudita in Pali and Sanskrit), but also karuna, or the compassionate feeling of another's suffering and the longing to extinguish it. This form of sorrow is welcome in the Bodhisattva path not only because it amounts to the erosion or the transcendence of the ego, but also because it is necessary for more social, global, and even cosmic transformation. The Bodhisattva vows to "take upon myself the burden of all suffering. . . And why? . . My endeavors do not merely aim at my own deliverance. . . I must rescue all beings from the stream of samsara. ... So I will help all beings to freedom, in all the states of woe that may be found in any world whatsoever." 359 Here, the suffering of other sentient beings serves as an indexical symbol that conforms not just the Bodhisattva, but all sentient beings, to the ultimacy of the awareness of Emptiness. So while the sorrow of the Calvinist weakens the will to the end of submission to a sovereign ontological Other and the sorrow of the Christian mystic is a necessary step toward union with an ontological Other, the bodhisattva endures the sorrow of samara to help others toward awareness that there is no ontological permanence — an awareness that will free others from the desire-rooted disease and sorrow of the human condition.

\footnotetext{
358 Julius Rubin, "Melancholy," in The Oxford Handbook of Religion and Emotion, ed. John Corrigan (Oxford: Oxford University Press, 2008), 297.

359 Santideva, "Siksasamuccaya," in Buddhist Texts Through The Ages, ed. Conze et al. (New York: Harper \& Row, 1964), 131-2.
} 


\section{The Passions of Fear and Daring}

Aquinas's treatment of fear is similar in structure to his treatment of other specific passions. He begins by specifying fear in contrast to other passions by paying close attention to the object of fear. For Aquinas, three necessary conditions of the object of fear are 1) that it be a perceived evil, 2) that the evil is perceived as a future evil, and 3) that the future evil be perceived as difficult to avoid. Aquinas devotes an entire question to drawing out the ramifications of these conditions to further clarify the logic of fear. He begins by addressing objections which state that the object of fear may be some good. His objectors note that the object of fear is often some perceived good, particularly power, God, and the loss of good things. Aquinas responds that fear can "regard good also, in so far as referable to evil."360 For example, fear may regard health insofar as one fears the loss of health. But the object of fear is the loss of health (an evil) rather than health itself. Also, fear may regard some perceived good as the cause of evil. While power may be good in itself, it can be a cause of some perceived evil. Aquinas writes that "one fears to be over another, i.e. to lean on another, so that it is his power to do us a harm: thus a man fears another, who knows him to be guilty of a crime, lest he reveal it to others." ${ }^{\mathbf{3 6 1}}$ We do not fear power in itself. Rather, we fear the power of others insofar as it leaves us vulnerable. Likewise, Aquinas notes that people do not fear God as God, but

\footnotetext{
${ }^{360}$ Thomas Aquinas, Summa Theologiae I-II, q. 42, a. 1, trans. Fathers of the English Dominican Province (New York: Benzinger Bros., 1948).

${ }^{361}$ Thomas Aquinas, Summa Theologiae I-II, q. 42, a. 1, trans. Fathers of the English Dominican Province (New York: Benzinger Bros., 1948).
} 
the punishments of God when such punishments are perceived as evil in some way. ${ }^{\mathbf{3 6 2}}$ Thus, the proper object of fear is always some perceived evil.

Aquinas's objectors also note that certain evils, like death and illness, are always threatening. If such evils were an object of fear, then we would always be in a state of fear. ${ }^{363}$ Aquinas responds that since fear arises from the imagination of a future evil, "whatever removes the imagination of the future evil, removes fear also."364 If our own death is not present to our imagination as a future event, it cannot serve as the object of fear. We can distract ourselves from the imagination of our own death by directing our attention elsewhere. When we do contemplate our own deaths, we often think about it abstractly and not as a real possibility. As Aquinas writes, by thinking of our own death as remote and far off, "such a thing is considered as though it were not to be."365 Aquinas also notes that fear ceases when hope of escape ceases. When there is no hope of escape, the object is not perceived as a future, threatening evil, but a present, fulfilled evil. The object of fear is considered to be probable rather than certain. Thomas Miner's offers an analogy: "like the object of a photographer's lens that comes into focus, the threatening evil can be neither too close nor too far away. What makes something threatening, however, is not simply related to time. If no hope of escape exists, the evil loses its threatening character; it is perceived as virtually present, even if some time must pass before its actual arrival.,"366

\footnotetext{
${ }^{362}$ Thomas Aquinas, Summa Theologiae I-II, q. 42, a. 1, trans. Fathers of the English Dominican Province (New York: Benzinger Bros., 1948).

${ }^{363}$ Thomas Aquinas, Summa Theologiae I-II, q. 42, a. 2, trans. Fathers of the English Dominican Province (New York: Benzinger Bros., 1948).

${ }^{364}$ Thomas Aquinas, Summa Theologiae I-II, q. 42, a. 2, trans. Fathers of the English Dominican Province (New York: Benzinger Bros., 1948).

${ }^{365}$ Thomas Aquinas, Summa Theologiae I-II, q. 42, a. 2, trans. Fathers of the English Dominican Province (New York: Benzinger Bros., 1948).

${ }^{366}$ Thomas Miner, Thomas Aquinas on the Passions (Cambridge, Cambridge University Press, 2009), 239.
} 
Aquinas notes that the conditions of the object of fear entail that the object of fear be perceived as something outside the direct control of the will. From the fact that the object of fear is a future evil which is difficult to avoid, "we may gather that whatever is entirely subject to our own power and will, is not an object of fear; and that nothing gives rise to fear save what is due to an external cause."367 So, the kind of anxious vertigo that Sartre describes is not, as Sartre maintain, an awareness of our own freedom, but an awareness that we might slip. This awareness of our limits would seem to be an element not just of fear, but of all irascible emotions (hope, despair, fear, daring, and anger). In distinguishing the concupiscible and irascible emotions, Aquinas says that while the concupiscible passions involve the simple inclinations to seek the suitable and avoid the harmful, through the irascible passions, "the animal resists these attacks that hinder what is suitable, and inflict harm. ... Whence we say that its object is something arduous, because its tendency is to overcome and rise above obstacles." ${ }^{, 368}$ Diana Fritz Cates explains that the irascible passions arise "when one apprehends an obstacle to attaining what one wants, or avoiding what one wants to avoid." 369 This observation is a central thesis in Philip Fisher's work on the vehement passions. Fisher argues that the vehement passions (fear, anger, shame, etc.) mark "the contours of the limited radius of our will by means of the injuries and humiliations of that will that are signaled to us by moments when we find ourselves in a state of vehemence - that is, in an impassioned state., ${ }^{370}$

\footnotetext{
${ }^{367}$ Thomas Aquinas, Summa Theologiae I-II, q. 42, a. 3, trans. Fathers of the English Dominican Province (New York: Benzinger Bros., 1948).

${ }^{368}$ Thomas Aquinas, Summa Theologiae I q. 81, a. 2, trans. Fathers of the English Dominican Province (New York: Benzinger Bros., 1948).

${ }^{369}$ Diana Fritz Cates, Aquinas on the Emotions: A Religious-Ethical Inquiry (Washington, D.C.: Georgetown University Press, 2009), 117.

${ }^{370}$ Philip Fisher, The Vehement Passions (Princeton and Oxford: Princeton University Press, 2002), 280.
} 
Thus, for an object to be an object of fear, it must be a future evil that is perceived to be out of the control of one's will.

Aquinas also discusses the varieties of fear, based upon the varieties of possible objects of fear. Fear can vary both in terms of intensity and form. Regarding the former, Aquinas argues that, all other things being equal, sudden evils are feared with greater intensity. Aquinas notes that difficulty as a necessary condition of fear "is due to one of two causes: to the greatness of the evil, or to the weakness of him that fears; while unwontedness and suddenness conduce to both causes."371 Sudden evils are perceived to be greater evils and the suddenness deprives the subject of resources to overcome or forestall the evil. Aquinas cites an example of a rich man who suddenly becomes poor. The poverty is all the more disagreeable due to its suddenness. The fear of a rich man who fears he will lose all his savings in a recent gamble is more vehement then the fear of a rich man who fears his expenses will slowly erode his wealth. The intensity of fear is also affected by whether the subject perceives there to be any remedy to the evil he/she fears. "The object of fear is evil: consequently whatever tends to increase evil, conduces to the increase of fear. Now evil is increased not only in its species of evil, but also in respect of circumstances. ... And of all the circumstances, longlastingness, or even everlastingness, seems to have the greatest bearing on the increase of evil."372 Thomas Miner offers fear of chemical and nuclear warfare as examples of fear of an evil with no

\footnotetext{
${ }^{371}$ Thomas Aquinas, Summa Theologiae I-II q. 42, a. 5, trans. Fathers of the English Dominican Province (New York: Benzinger Bros., 1948).

${ }^{372}$ Thomas Aquinas, Summa Theologiae I-II q. 42, a. 6, trans. Fathers of the English Dominican Province (New York: Benzinger Bros., 1948).
} 
remedy. The fact that the suffering associated with chemical and nuclear warfare last for many years makes these events particularly terrible. ${ }^{373}$

In addition to intensity, Aquinas also delineates various forms of fear based on the circumstances of the object of fear. In this context, he attempts to defend the traditional list of species of fear given by Damascene as "laziness, shamefacedness, shame, amazement, stupor, and anxiety." ${ }^{, 374}$ Thomas Miner suggests that the unusual amount of objections to this traditional list that Aquinas offers shows he recognizes the tradition involves some difficulty. Nonetheless, Aquinas defends the tradition by analyzing laziness as fear of work that burdens one's nature; shamefacedness as fear of social disgrace as a result of a deed yet to be done; shame as fear of social disgrace as a result of a deed already done; amazement as fear of a great evil the outcome of which the subject is unable to gauge; stupor as fear of some unusual, strange, or unwonted evil; and anxiety as fear of some evil under the aspect of unforseeability. While we might question the details of these analyses or wish for more specification, the important point here is that Aquinas's basic framework can be used to analyze emotions not included in the eleven basic passions.

Aquinas concludes his treatment of fear by considering its causes and effects. Aquinas argues for two necessary causes of fear: love and defect. Aquinas begins by recalling the distinction between the object and cause of a passion. The object of a passion is the formal properties of any possible target of fear (a perceived, future evil that is difficult to avoid). The cause of a passion, on the other hand, is whatever serves as a

${ }^{373}$ Thomas Miner, Thomas Aquinas on the Passions (Cambridge, Cambridge University Press, 2009), 242. ${ }^{374}$ Thomas Aquinas, Summa Theologiae I-II q. 41, a. 4, trans. Fathers of the English Dominican Province (New York: Benzinger Bros., 1948). 
cause of the object of the passion. ${ }^{375}$ Aquinas then distinguishes between the efficient and material causes of fear. Since the object of fear is some future evil, "that which can inflict such an evil, is the efficient cause of the object of fear, and, consequently of fear itself." 376 In the case of an adolescent who fears being grounded on the night of the party, his/her parents would serve as an efficient cause. The material cause, on the other hand, is "that which renders a man so disposed [such that the object] is such an evil to him. ${ }^{, 377}$ If I fear being bitten by some particular dog, the owner who just let the dog off the leash might be an efficient cause of the fear, while some dramatic childhood encounter with another dog might be a material cause. As Robert Miner expresses it, a material cause of fear is anything that "dispose[s] a person to construe something as possessing features that inspire fear, that is, to perceive the thing as an obiectum timoris. ${ }^{, 378}$ For Aquinas, love is a necessary material cause of fear "since it is through his loving a certain good, that whatever deprives a man of that good is an evil to him, and that consequently he fears it as evil."379 Thus, the adolescents's love for someone at the party might serve as a material cause of the adolescent's fear of being grounded. Love of myself serves as a material cause of my fear of the dog. Fear, like all other emotions, is grounded in love. Defect is also a necessary material cause of fear "for it is owing to some lack of power that one is unable easily to repulse a threatening evil." ${ }^{380}$ Given the

\footnotetext{
375 Thomas Aquinas, Summa Theologiae I-II q. 43, a. 1, trans. Fathers of the English Dominican Province (New York: Benzinger Bros., 1948).

${ }^{376}$ Thomas Aquinas, Summa Theologiae I-II q. 43, a. 1, trans. Fathers of the English Dominican Province (New York: Benzinger Bros., 1948).

377 Thomas Aquinas, Summa Theologiae I-II q. 43, a. 1, trans. Fathers of the English Dominican Province (New York: Benzinger Bros., 1948).

378 Thomas Miner, Thomas Aquinas on the Passions (Cambridge, Cambridge University Press, 2009 ), 242.

379 Thomas Aquinas, Summa Theologiae I-II q. 43, a. 1, trans. Fathers of the English Dominican Province (New York: Benzinger Bros., 1948).

${ }^{380}$ Thomas Aquinas, Summa Theologiae I-II q. 43, a. 2, trans. Fathers of the English Dominican Province (New York: Benzinger Bros., 1948).
} 
object of fear must appear as threatening, it must limit our will to some extent. So, our limited will disposes us to perceive objects as threatening.

In addressing the effects of fear, Aquinas gives due attention to the feeling aspect of fear. Aquinas reiterates his view that the passions are necessarily psychosomatic. The movement of the sensitive appetite is the formal element of the passion, while the bodily change is the material element. Aquinas claims these two elements are generally proportionate in degree and that the bodily transmutation resembles the appetitive movement in some way. ${ }^{381}$ Since the motivational component of fear involves a kind of retreat, Aquinas suggests there is a similar somatic effect of contraction. More specifically, "a similar contraction of heat and vital spirits towards the inner parts takes place in regard to the body." ${ }^{, 382}$ While this is obviously outdated physiology, Thomas Miner notes a certain value in Aquinas's remarks. "The conviction that motivates [Aquinas's claim] retains its validity. The conviction is that different motions of the sensitive appetite will produce corresponding different somatic effects. Feeling hot with anger or cold with fear are experiences grounded in nature. While the explanans may change as natural science changes, the explanandum will remain the same. ${ }^{383}$ Given Aquinas's view that the body and soul are fundamentally integrated, he avoids the view that the somatic effects are simply 'added-on' to the essential cognitive, evaluative, and motivational components. The formal and material aspects of the passions are closely intertwined. As Peter Goldie argues, "our entire mind and body is engaged in the

\footnotetext{
${ }^{381}$ Thomas Aquinas, Summa Theologiae I-II q. 44, a. 1, trans. Fathers of the English Dominican Province (New York: Benzinger Bros., 1948).

${ }^{382}$ Thomas Aquinas, Summa Theologiae I-II q. 44, a. 1, trans. Fathers of the English Dominican Province (New York: Benzinger Bros., 1948).

${ }^{383}$ Thomas Miner, Thomas Aquinas on the Passions (Cambridge, Cambridge University Press, 2009), 247.
} 
emotional experience, and all the feelings are 'united in consciousness' in being directed toward its object: united 'body and soul,' 'heart and mind.",384

Aquinas devotes considerably less space to the passion of daring than he does to fear. Aquinas is content to briefly discuss the relationship of daring to both fear and hope and then quickly note its causes and effects. Aquinas argues that daring is the contrary of fear in the sense that "fear turns away from the future hurt, on account of its victory over him that fears it; whereas daring turns on threatened danger because of its own victory over that same danger." ${ }^{385}$ As this quote illustrates, there is a parallel between daring and despair. Just as despair retreats from the good because it seen as impossible to obtain, so daring approaches evil because it is seen as possible to overcome. This observation leads Aquinas to the position that daring proceeds from hope "since it is in the hope of overcoming the threatening object of fear, that one attacks it boldly." ${ }^{386}$ So, just as despair presupposes a fear of losing some good, so daring presupposes the hope of overcoming some evil. Aquinas's analysis of daring is similar to Aaron Ben-Ze'ev's analysis of courage (considered simply as an affective state rather than a virtue). BenZe'ev writes that "the most significant difference between fear and courage concerns the motivational component: whereas in fear flight is the typical behavior, in courage the agent usually confronts the threat, as the agent believes she can successfully overcome it." ${ }^{387}$ As Ben-Ze'ev's final clause suggests, the object of daring is construed differently than the object of fear. In fear, the object is perceived as evil and unlikely to be avoided,

\footnotetext{
${ }^{384}$ Peter Goldie, The Emotions: A Philosophical Exploration (Oxford: Clarendon Press, 2000), 55.

385 Thomas Aquinas, Summa Theologiae I-II q. 45, a. 1, trans. Fathers of the English Dominican Province (New York: Benzinger Bros., 1948).

${ }^{386}$ Thomas Aquinas, Summa Theologiae I-II q. 45, a. 2, trans. Fathers of the English Dominican Province (New York: Benzinger Bros., 1948).

${ }^{387}$ Aaron Ben-Ze'ev, The Subtlety of Emotions (Cambridge, MA: Massachusetts Institute of Technology, 2000), 483.
} 
whereas in daring, the object is perceived as likely to be overcome. Whereas the object of fear is perceived to be outside the control of one's will, the object of daring is perceived to be at the very limit, but not beyond the limit, of one's will. So whereas weakness and defect dispose one to construe an object as fearful, strength, previous experiences of danger, and external assistance predispose one to view an evil as worth trying to overcome. ${ }^{388}$

\section{Religious Fear and Daring}

In the Christian tradition, perhaps there is no more paradigmatic symbol of fear than the symbol of hell. The object of the fear of hell is a future state which one apprehends as profoundly unsuitable and nearly impossible to avoid without divine grace. Diane Fritz Cates observes that "the object of this fear can become increasingly abstract as one moves, say, from the image of being burned in a fire . . to the thought that this image . . . is but a way of trying to imagine what it would be like to live in complete absence of goodness ... to the thought that repeated acts of wrong doing give rise to habits that destroy one's capacity to function well as a human and destroy one's capacity even to recognize that this destruction is taking place." ${ }^{, 39}$ But however one understands the object of the symbol of hell, the symbol itself remains one of the sensory imagination. And this sensory quality of the symbol is necessary to engender the passion of fear. As Cates notes, the abstract idea of evil or the ideal that moral violation is its own

\footnotetext{
388 Thomas Aquinas, Summa Theologiae I-II q. 45, a. 3, trans. Fathers of the English Dominican Province (New York: Benzinger Bros., 1948).

${ }^{389}$ Diana Fritz Cates, Aquinas on the Emotions: A Religious-Ethical Inquiry (Washington, D.C.: Georgetown University Press, 2009), 218.
} 
punishment does not cause a human being to fear or panic apart from concrete sensory representation. $^{390}$

Cates's observation is one that Jonathan Edwards was clearly aware of when writing his (in)famous sermon Sinners in the Hands of an Angry God. Edwards creates vivid images of hell in the attempt to awaken the congregation from their spiritual slumber. The language and theology of Edwards stresses the complete vulnerability of unbelievers: "the Pit is prepared, the Fire is made ready, the Furnace is now hot, ready to receive them, the Flames do now rage and glow. The glittering Sword is whet, and held over them, and the Pit hath opened her Mouth under them." ${ }^{391}$ Edwards emphasizes that it is only because of the will of God that unbelievers are not already burning in hell, adding to the sense of the precarious nature of their situation. It is only the hand of God, which He could at any moment remove, that prevents the unbelievers from slipping into the Devil's pit. The presentation of hell at any moment is entirely outside the will and control of the unbeliever. Edwards explicitly address the ability of the unconverted to distract themselves from this possibility by redirecting their imagination. "You probably are not sensible of this; you find you are kept out of Hell, but don't see the Hand of God in it, but look at other Things, as the good State of your bodily Constitution, your Care of your own Life, and the Means you use for your own Preservation. But indeed these Things are nothing." ${ }^{392}$ Edwards forcefully returns hell to the imagination of his congregation to awaken them to the danger of their condition and orient their attitudes and concerns in a salvifically productive manner.

\footnotetext{
${ }^{390}$ Diana Fritz Cates, Aquinas on the Emotions: A Religious-Ethical Inquiry (Washington, D.C.: Georgetown University Press, 2009), 218.

391 Jonathan Edwards, Sinners in the Hands of an Angry God (Boston: S. Kneeland and T. Green, 1741$), 7$. 392 Jonathan Edwards, Sinners in the Hands of an Angry God (Boston: S. Kneeland and T. Green, 1741), 12.
} 
Edwards elicits fear initially as a means of cognitive transformation. He writes that "whatever some have imagined and pretended about Promises made to natural Men's earnest seeking and knocking, 'tis plain and manifest that whatever Pains a natural Man takes in Religion, whatever Prayers he makes, till he believes in Christ, God is under no manner of Obligation to keep him a Moment from eternal destruction." ${ }^{\text {,393 }}$ An admirer of St. Augustine, Edwards would have been aware of his claim that the process of holiness is the transformation of fear of God into love of God. But belief, for Edwards, seems to be an intermediary. Here, transformation of belief is salvifically prior to practice such as prayer. In other traditions, however, symbols of fear are most directly intended to shape practice or other affections. Diane Fritz Cates offers an example of a Tibetan Buddhist nun who cites her biggest fear, when she is tempted to neglect her duties, is that she will be reincarnated into a much lower life form such as an ant. ${ }^{394}$ The image of being reincarnated into some particular lower life form serves as an indexical symbol attuning the nun toward ultimacy. Instead of a cognitive transformation, the most immediate purpose of the symbol of reincarnation in this case is practical- to keep the nun from neglecting her sacred obligations. In his classic work on male initiation rituals in New Guinea, social anthropologist Donald Tuzin observes how rites of terror can be used to inspire feelings of love, gratitude, and "deep identification" in the novice for the initiators. ${ }^{395}$ He identifies similarities between the novice-initiator relationship and Stockholm syndrome where hostages express empathy toward their captors. In such rites,

\footnotetext{
393 Jonathan Edwards, Sinners in the Hands of an Angry God (Boston: S. Kneeland and T. Green, 1741), 11. Emphasis added.

394 Diana Fritz Cates, Aquinas on the Emotions: A Religious-Ethical Inquiry (Washington, D.C.: Georgetown University Press, 2009), 220.

395 Donald F. Tunzin, The Voice of Tambaran: Truth and Illusion in Ilahita Arapesh Religion (Berkeley: University of California Press, 1980), 77-79.
} 
the rituals serve as indexical symbols which attune the passions to certain religiously normative standards. In this case, the affective transformation is most immediate and prior to the cognitive and the practical. In the following chapter, we will explore the relationship between religious beliefs, practice, and emotion. But for now, we can note how symbols of fear can be put to different immediate purposes.

Hebrew scriptures are filled with religious symbols of daring. Any narrative describing someone who obeys the will of God in the face of danger can serve as such a symbol. Moses raising his staff; Rahab keeping her secret; David picking up his stones; Esther entering into the king's presence; and Daniel praying in the den all serve as heroic ideals. Similarly, the Christian New Testament is permeated with symbols of daring. The prodigal son risks rejection and humiliation in his return home. The author of Acts writes of the boldness of Peter and John in the face of the threats of the elder council. Anna M. Gade notes that in the Islamic tradition, Muhammad serves as a "beautiful model." "Through an affective focus and devotion to the prophet, as developed in the 'middle period' (1270-1700) of Islam, Muslims may in effect achieve a radical internalization of the idea of sunnah, ${ }^{, 396}$ a guide for normative behavior based on the life and practice of the Prophet. Like Peter and John, Muhammad dares to follow the divine command to recite to a Meccan community unwilling to hear. What all of these narratives have in common is that, at least on a prima facie reading, the danger to be faced with daring is quite real, but the daring necessary for the task at hand is secured by a confidence in a divine plan or divine external assistance.

\footnotetext{
${ }^{396}$ Anna M. Gade, "Islam," in The Oxford Handbook of Religion and Emotion, ed. John Corrigan (Oxford: Oxford University Press, 2008), 43.
} 
However, in other religious hero narratives, the courage necessary to meet a threat is gained when the threat is put into its proper perspective. It is not the assurance of divine power by which the hero moves from fear to daring, but in the awareness of the danger's weakness. In the Bhagavad Gita, the saintly warrior Arjuna, who is profoundly disturbed at the prospect of civil war, is faced with his social duty as a warrior to protect his family. The Divine Lord, Krishna, offers the following advice to the fear stricken and wary general: "What is this weakness? It is beneath you. Is it for nothing men call you the foe-consumer? Shake off this cowardice Arjuna. Stand up. Your words are wise, Arjuna, but your sorrow is for nothing. The truly wise mourn neither for the living nor the dead. There was never a time when I did not exist, nor you, nor any of these kings. Nor is there any future in which we shall cease to be. ${ }^{״ 397}$ In this case, the evil Arjuna feared and grieved over was ultimately illusory. "Just as the dweller in this body passes though childhood, youth, and old age, so at death he merely passes into another kind of body. The wise are not deceived by that. ${ }^{, 398}$ Krishna summons Arjuna's daring by helping him realize the Eternal Self within. Krishna proceeds with a lengthy teaching on the ways of the illumined person, one who is not longer enslaved to action and dragged on by selfish desire. Krishna reminds Arjuna the real foe he must dare to consume is himself. Of the two wars Arjuna is facing, the war against his own ego is, as the Muslim would say, the greater jihad.

\section{The Passion of Anger}

\footnotetext{
${ }^{397}$ Philip Novak, ed., "The Bhagavad Gita," in The World's Wisdom (New York: HaperCollins Publishers, 1994), 27.

${ }^{398}$ Philip Novak, ed., "The Bhagavad Gita," in The World's Wisdom (New York: HaperCollins Publishers, 1994), 27.
} 
The nature of anger among the passions is unique and complex in many ways according to Aquinas's account. First, anger is caused by a concurrence of several emotions "because the movement of anger does not arise save on account of some pain inflicted, and unless there be desire and hope of revenge. ${ }^{399}$ Anger only arises when the endurance of sorrow is combined with a desire for vindication. Secondly, anger is complex in the sense that its object is twofold. Aquinas insists that it is not entirely correct to say that the object of anger is some evil, for anger consists in both a desire for vengeance (a perceived good) upon some person or for some slight that bears the character of evil. ${ }^{400}$ So, while in ordinary language it is common to express the object of anger as some evil, Aquinas holds that desire and hope, in addition to the sorrow of some slight, are necessary preconditions for anger. Finally, anger is unique in that is has no contrary. From the fact that anger is a complex emotion including elements of desire, hope, and sorrow, "it includes in itself contrariety: and consequently it has not contrary outside itself. Thus also in mixed colors there is no contrariety, except that of the simple colors from which they are made.."${ }^{401}$ However, this color analogy should not be taken too far. Aquinas later explains that "anger is said to be composed of sorrow and desire, not as though they were its parts, but because they are its causes. ${ }^{, 402}$ It is for this reason

\footnotetext{
${ }^{399}$ Thomas Aquinas, Summa Theologiae I-II q. 46, a. 1, trans. Fathers of the English Dominican Province (New York: Benzinger Bros., 1948). Thomas Miner notes that the term 'revenge' in this quote is a mistranslation. 'Vindicta does not mean 'revenge' or even necessarily 'vengeance,' as the term is often translated. When Aquinas wants to convey what English-speakers usually mean by 'revenge,' he will use a form of ulcisor. The appetite for revenge is one mode of seeking vindication, but vindicta ipsa cannot be reduced to revenge." Miner translates vindicta as "vindication." See Thomas Miner, Thomas Aquinas on the Passions (Cambridge, Cambridge University Press, 2009), 271.

${ }^{400}$ Thomas Aquinas, Summa Theologiae I-II q. 46, a. 2, trans. Fathers of the English Dominican Province (New York: Benzinger Bros., 1948).

${ }^{401}$ Thomas Aquinas, Summa Theologiae I-II q. 46, a. 1, trans. Fathers of the English Dominican Province (New York: Benzinger Bros., 1948).

402 Thomas Aquinas, Summa Theologiae I-II q. 46, a. 3, trans. Fathers of the English Dominican Province (New York: Benzinger Bros., 1948).
} 
that Aquinas holds anger to be a basic passion as opposed to a species or form of either desire, sorrow, or both. Aquinas is fairly explicit about his commitment to the eleven passions as being basic and the only basic passions: "Consequently, there are all together eleven basic passions differing specifically; six in the concupiscible, and five in the irascible; and under these all the passions of the soul are contained." ${ }^{403}$ I believe Aquinas's insistence on both the complex nature of anger and its status as a basic passion leads to some difficulties. But before I can address these difficulties, we must first examine Aquinas's view on the relationship between anger and reason.

Yet another unique feature of anger, according to Aquinas, is that it is not only possible for anger to participate in reason, but "anger, in a fashion, requires an act of reason. ${ }^{404}$ On Aquinas's line of thinking, the desire for vindication implies a comparison between the offense and the punishment. Since such a comparison is an inference, which is an act of reason, anger requires an act of reason. This would seem to imply that anger is a uniquely human emotion. Aquinas responds that animals have something analogous to anger by virtue of a "natural instinct imparted to them by the Divine Reason. ${ }^{, 405}$ I agree with Aquinas that paradigmatic cases of anger involve the desire for vindication. As Ben-Ze'ev observes, "In anger, we want to personally punish the other person who is seen as deserving punishment. ${ }^{, 406}$ The desire for vindication seems to be an essential feature of the object of anger, for anger generally subsides if we come to view the once offensive action as unintentional. We might speak of getting

\footnotetext{
${ }^{403}$ Thomas Aquinas, Summa Theologiae I-II q. 23, a. 4, trans. Fathers of the English Dominican Province (New York: Benzinger Bros., 1948).

${ }^{404}$ Thomas Aquinas, Summa Theologiae I-II q. 46, a. 4, trans. Fathers of the English Dominican Province (New York: Benzinger Bros., 1948).

${ }^{405}$ Thomas Aquinas, Summa Theologiae I-II q. 46, a. 4, trans. Fathers of the English Dominican Province (New York: Benzinger Bros., 1948).

${ }^{406}$ Aaron Ben-Ze'ev, The Subtlety of Emotions (Cambridge, MA: Massachusetts Institute of Technology, 2000), 384.
} 
angry at inanimate objects when they thwart our will, but in such cases we can more carefully distinguish frustration or annoyance from anger. However, I have trouble attributing the desire for vindication to non-rational animals, even with the aid of divine assistance. Similarly, Thomas Miner suggests that "for animals, the [distinction between daring and anger] comes close to breaking down."407 So, I suggest we step fully into the view toward which Aquinas leans - that anger is peculiar to rational beings.

However, this position of anger as a rational emotion might be devastating to Aquinas's insistence on its status as a basic emotion. Terruwe and Baars remark that it is odd that an emotion of the sensory appetite would derive its distinguishing characteristic from reason. Additionally, they argue that it is not clear how animal rage could have anything to do with revenge, rather that a defense against further evil. ${ }^{408}$ This leads Terruww and Baars to suggest that anger and daring should not be seen as separate emotions, but differing forms of the same emotion. While anger always presupposes a present or past evil, "it is also possible for a threatening danger to bring about all the symptoms of anger and rage. And when the manifestations are the same, one should assume the emotions are one and the same."409 Aquinas would rightly disagree with this last statement. It is the object that differentiates emotions, not the expressions. Joy and embarrassment might both manifest in a smile, but these are certainly not the same emotions. And there is a difference in object between daring and anger. Daring's object is a future, threatening evil which is perceived as worth trying to overcome, while the object of anger is necessarily, in part, a present or past evil. It is not clear to me,

\footnotetext{
407 Thomas Miner, Thomas Aquinas on the Passions (Cambridge, Cambridge University Press, 2009), 266.

${ }^{408}$ Anna A. Terruwe, MD and Conrad W. Baars MD, Loving and Curing the Neurotic: A New Look at Emotional Illness (New Rochelle, NY: Arlington House, 1972), 37n10.

409 Anna A. Terruwe, MD and Conrad W. Baars MD, Loving and Curing the Neurotic: A New Look at Emotional Illness (New Rochelle, NY: Arlington House, 1972), 37n10.
} 
however, why Aquinas insists on anger being a basic passion when other emotions which are similar in terms of their complex nature are not. We saw, for instance, how Aquinas's analyzes compassion in terms of both sorrow at another's misfortune or suffering and a desire to alleviate such suffering. One could offer a similar analysis of anger such that anger is sorrow at one's own unjust suffering and a desire for vindication. Thus, contra Aquinas, I think it makes more sense to consider anger as a complex emotional state involving both longing and sorrow. ${ }^{410}$ But the rationale for Aquinas's insistence on anger as a basic passion is not crucial for my purposes here. Basic or not, anger is an important emotion in religious contexts.

\section{Religious Anger}

According to many saintly ideals, the emotion of anger is one to be eliminated rather that purposively inculcated. This is perhaps due to the common observation that anger can be a particularly powerful and consuming passion. Just as there is no such thing as virtuous hatred in Theravada Buddhism, the same is true for virtuous anger. Many Buddhist meditative techniques are designed to ameliorate negative emotional experiences such as anger. For example, Maria Heim explains that in mindfulness meditation, "a part of the mind can learn to stand back and observe the rage arise, noting it conditions, its arc, and its dissipation. ... To observe mental episodes and habits in this way does much of the work of liberating us from them; one is no longer swallowed whole

\footnotetext{
${ }^{410}$ In addition to making more sense in terms of the logic of anger, thinking of anger as a non-basic passion has the additional advantage of satisfying my rather Thomistic desire for symmetry. This would make for ten basic passions (five of attraction and five of repulsion), each with its own contrary.
} 
by anger.",411 We also observed in the section on disgust that according to some Jewish mystical traditions, anger is a symptom of pride that must be at least tightly controlled if not eliminated altogether.

However, there are examples of anger directed at symbols of ultimacy as a means of soteriological transformation. One good example occurs in the Hebrew narrative of King David and the prophet Nathan. After David commits adultery with and impregnates Bathsheba, he murders her husband in order to quickly marry her. God sends Nathan to confront the King. Nathan purposively awakens David's anger by telling him a story of injustice symbolizing David's own actions. A rich man, with many sheep, steals the sole lamb of a poor man and prepares it for a feast in honor of a visitor. "Then David's anger was greatly kindled against the man. He said to Nathan, 'As the Lord lives, the man who has done this deserves to die; he shall restore the lamb fourfold, because he did this thing, and because he had no pity."412 Nathan's story serves as an indexical symbol awakening David to his own injustice. "Nathan said to David, 'You are the man! . . Why have you despised the word of the Lord, to do what is evil in his sight?" succeeds in arousing David's anger, the narrative is somewhat ambiguous as to whether David's pattern of concern was conformed to God's care and concern. Whereas David may have previously felt entitled to Bathsheba such that the feeling of guilt could not arise, David now recognizes his own sin. But it is not clear whether David now feels genuine contrition and anger at his own deeds, or only regrets the consequences of divine punishment. Nathan prophecies future political conflicts, the death of the child, and the

\footnotetext{
${ }^{411}$ Maria Heim, "Buddhism," in The Oxford Handbook of Religion and Emotion, ed. John Corrigan (Oxford: Oxford University Press, 2008), 25.

412 II Samuel 12:5-6. NRSV.

${ }^{413}$ II Samuel 12:7-9. NRSV.
} 
fact that one of David's own wives will be given to his neighbor before his own eyes. In response, David displays outward forms of contrition such as fasting in the hopes of avoiding the death of the child. But he quickly abandons these displays once the child dies, suggesting his concern was for his own future loss of fortune rather than his violation of God's law. While the narrative within the narrative may not have been successful in appropriately attuning David's heart, the larger narrative can serve as a devotional symbol for the contemporary reader. It reminds the reader how easily one can deceive oneself into thinking that that they are genuinely contrite, when in fact they simply fear punishment or are ashamed of their external disgrace.

We also can find examples in theistic traditions where, in certain circumstances, anger at God is deemed to be religiously/ethically valuable. In a film interview, Elie Wiesel describes a trial of God performed by three learned men in Auschwitz. After describing the solemnity and seriousness of the trail and the guilty verdict, Wiesel added that "I would like to do a story on that one day ... but I will introduce a new character who defends God, the only one who defends God, the only one who says that God's ways are justified even in Auschwitz. And I would say that that character is Satan. . . For a Jew to believe in God is good. For a Jew to protest against God is still good. But simply to ignore God - that is not good. Anger, yes. Protest, yes. Affirmation, yes. But indifference? No. You can be a Jew with God. You can be a Jew against God. But not without God." ${ }^{414}$ If affirmation of God's sovereign will is no longer possible in the twenty-first century, perhaps anger is. In this theodicy of protest, the image of God on trail with a Satan defense attorney serves as a symbol of ultimacy toward which anger is

\footnotetext{
${ }^{414}$ Elie Wiesel, "The Holocaust: Elie Wiesel on the Trail of God," in The World's Wisdom, ed. Philip Novak (New York: HaperCollins Publishers, 1994), 224.
} 
directed. In this context, it is of ultimate importance not to succumb to the evil of indifference and the symbol attunes the concern of interpreter appropriately.

\section{Conclusion}

The account of religious emotions offered in these pages can illustrate not only common patterns of characteristic emotional experience across religious boundaries, but can also shed light on the diversity and uniqueness of emotional-religious life both across and within religious traditions. Viewing religious emotions as forms of concern toward symbols of ultimacy in a devotional context can help clarify the function of symbols in the religious life and how they are used in various patterns of transformation. However, religion as a set of interrelated and traditional human practices performed in response to perceived ultimacy has as its goal not merely emotional transformation and attunement, but a transformation of the entire self-heart, mind, and strength. In the next and final chapter of this project, we will explore the relationship between religious emotions, beliefs, and practice in order to illustrate the role of the emotions in the broader religious life. 


\section{CHAPTER FIVE}

\section{RELIGIOUS EMOTION, COGNITION, AND PRACTICE}

\section{Introduction}

In the previous two chapters, I applied my account of religious emotions generally to an analysis of particular religious emotions and emotional patterns in order to illustrate the promise of the framework in comparative religious studies. In this final chapter of the project, I want to broaden my focus back to religious emotions generally in order to explore the relationship between emotion, cognition, and practice in the religious life. David Morgan notes that "the academic study of religion in the modern West has been shaped by the idea that a religion is what someone believes, which consists of a discrete, subjective experience of assent to propositions concerning the origin of the cosmos, the nature of humanity, the existence of deities, or the purpose of life." ${ }^{, 415}$ While this overemphasis on belief may be loosening in religious studies generally, Morgan's statement is still largely true of contemporary analytic philosophy of religion. Whether religious beliefs are epistemically justified/warranted or whether certain religious concepts are coherent still occupies a central place in the philosophical agenda. ${ }^{416}$ But as Leszek Kalokowski reminds us, "Religion is not a set of propositions, it is the realm of worship wherein understanding, knowledge, and the feeling of participation in the

415 David Morgan, "Introduction: The Matter of Belief," in Religion and Material Culture, ed. David Morgan (London and New York: Routledge, 2010), 1.

${ }^{416}$ See article titles from the 2012 volumes of Religious Studies: An International Journal for the Philosophy of Religion. 
ultimate reality and moral commitment [all] appear as a single act, whose subsequent segregation into separate classes of metaphysical, moral and other assertions might be useful, but is bound to distort the sense of the original act of worship." ${ }^{\not 17}$ Similarly, Paul Tillich observes that "faith as being ultimately concerned is a centered act of the whole personality. If one of the functions which constitute the totality of the personality is partly or completely identified with faith, the meaning of faith is distorted." ${ }^{, 418}$ The aim of this chapter is to show how Neville's understanding of religious symbols can help illuminate the relationship between emotion, cognition, and practice in a religious context that respects the integrity of the religious life that Kalokowski and Tillich mention. This chapter is divided into two sections. The first section explores the relationship between emotion and cognition in religious life. Here, I will make an important distinction between what I will call "mystical feelings" and religious emotions and explore the relationship between mystical feelings, religious understanding, and religious emotions. By religious understanding, I am referring to the broadly cognitive dimension of religion, which includes religious beliefs, doctrines, worldviews as well as objects of the imagination such as religious symbols (myths, icons, etc.). I will argue that while mystical feelings have a logical priority to religious understanding, they do not necessarily have a practical priority. While religious myths, beliefs, and doctrines arise historically out of the impulse provided by mystical feelings, individuals often experience mystical feelings after and through objects of religious understanding and with the aid of religious emotions. The second section will build off the first by discussing the role of religious practice in relation to religious emotions and understanding, arguing for what

${ }^{417}$ Leszek Kalalowski, Religion (South Bend: St. Augustine's Press, 2001), 165.

${ }^{418}$ Paul Tillich, The Dynamics of Faith (New York: Harper \& Row), 30. 
John Cottingham refers to as the "primacy of praxis." ${ }^{419}$ According to this view, it is of the very nature of religious understanding that it is rooted in and arises out of religious practice. I will add to Cottingham's point by further developing the concept of religious practice and show how religious emotions sustain the practices at the center of religious life. I will conclude by showing how this account of the relationship between religious understanding, practice, and emotion has the added advantage of squaring nicely with Aquinas's understanding of faith.

\section{Mystical Feelings, Religious Understanding, and Religious Emotions}

In his work The Felt Meanings of the World, Quentin Smith offers an interesting distinction between what he calls "the metaphysics of reason" and "the metaphysics of feeling." The metaphysics of reason is metaphysics as traditionally taught in philosophy departments. It is concerned with providing an explanation of the world as a whole. Why is there something rather than nothing? The metaphysics of feeling, on the other hand, "is concerned with the value or importance of the world, rather than with its causal or explanatory ground." ${ }^{420}$ Moreover, the most basic way of registering such value of the world as a whole is through what Smith calls "intuitive feelings of global importances." Smith explains that these intuitive, immediate registerings may vary in feeling from a kind of awesome fear to a marveling attraction. But in any case, there is a direct sense of a meaningful whole with a response of feeling. ${ }^{421}$

\footnotetext{
419 John Cottingham, The Spiritual Dimension: Religion, Philosophy and Human Value (Cambridge: Cambridge University Press, 2005), 5.

${ }^{420}$ Mark Wynn, Emotional Experience and Religious Understanding: Integrating Perception, Conception, and Feeling (Cambridge: Cambridge University Press, 2005), 63.

${ }^{421}$ Quentin Smith, The Felt Meanings of the World: A Metaphysics of Feeing (West Lafayette, IN: Purdue University Press, 1986).
} 
The feeling Smith describes is at least similar to what Wittgenstein labels the mystical. "It is not how things are in the world that is mystical, but that it exists. . . To view the world sub specie aeterni is to view it as a whole - a limited whole. Feeling the world as a limited whole-it is this that is mystical." ${ }^{, 422}$ In another writing, Wittgenstein describes this feeling as a sense of wonder, or what Smith labels a captivated marveling. "I believe the best way of describing [this experience] is to say that when I have it $I$ wonder at the existence of the world. And I am then inclined to use such phrases as 'how extraordinary that anything should exist' or 'how extraordinary that the world should exist." ${ }^{423}$ Martin Heidegger expresses a similar sentiment of mystical contemplation. "“Why are there beings, why is there anything at all, rather than nothing?' . . Many ... never encounter this question, if by encounter we mean not merely to hear and read about it [but] to feel its inevitability." ${ }^{424}$ One finds similar accounts of mystical feelings in Friedrich Schleiermacher's notion of "the feeling of absolute dependence" and Rudolf Otto's "mysterium tremendum." While much academic ink has been spilt on such mystical feelings, without getting mired in interpretative details we can say that such feelings have as their "object" either that which transcends finite particularities (the world as a whole) or the relationship between the self and that which transcends all existence. Additionally, such feelings are generally presented as non-discursive, non-conceptual, and immediately grasped. In his analysis of the mysterium, Otto writes that such an experience "strikes us dumb" for the mysterium is "that which is quite beyond the sphere of the usual, the intelligible, and the familiar, filing the mind with blank wonder and

\footnotetext{
422 Ludwig Wittgenstein, Tractatus Logico-Philosophicus, trans. D. F. Pears and B. F. McGuiness (London and New York: Routledge, 1961), 6.44, 6.55.

423 Ludwig Wittgenstein, "A Lecture on Ethics," The Philosophical Review 74 (1965): 8.

424 Martin Heidegger, An Introduction to Metaphysics, trans. Ralph Mannheim (Garden City, New York: Anchor Books, 1961), 1. Emphasis added.
} 
astonishment." ${ }^{225}$ Again, as Wittgenstein reminds us, "there are indeed things that cannot be put into words. They make themselves manifest. They are what is mystical."426

It is important to distinguish mystical feelings from what I have been referring to as religious emotions. Mystical feelings do not have as their object a religious symbol, but the world as a whole, the transcendent, or the relationship between the self and the transcendent. This is not to suggest that such states have nothing to do with the religious life. To the contrary, there is a long philosophical tradition of understanding such states to be the foundation of the religious life. In his 1830 edition of The Christian Faith, Friedrich Schleiermacher famously identified the basis of religion in a feeling of absolute dependence. "The piety which forms the basis of all ecclesiastical communions is, considered purely in itself, neither a Knowing nor a Doing, but a modification of Feeling." 427 Otto identifies the basis of religion in the feeling of coming into contact with the "the numinous," or the non-rational aspect of the Holy which cannot be apprehended conceptually, but only immediately intuited through feeling. ${ }^{428}$ William James writes that religious beliefs must "be classed as over-beliefs, buildings-out performed by the intellect into directions of which feeling originally supplied the hint." ${ }^{, 429}$ But James also noticed the distinction between pre-conceptual mystical feelings and what he referred to as religious sentiments, which are conceptual in the sense that they are simply ordinary emotions with reference to some type of religious object. James explains that "there is

425 Rudolf Otto, The Idea of the Holy, trans. John W. Harvey (Oxford: Oxford University Press, 1950), 26.

${ }^{426}$ Ludwig Wittgenstein, Tractatus Logico-Philosophicus, trans. D. F. Pears and B. F. McGuiness (London and New York: Routledge, 1961), 6.522.

427 Friedrich Schleiermacher, The Christian Faith, trans. H. R. Mackintosh and J. S. Stewart (Edinburg: T. \& T. Clark, 1999), 5.

428 Rudolf Otto, The Idea of the Holy (London: Oxford University Press, 1950).

${ }^{429}$ William James, The Varieties of Religious Experience: A Study in Human Nature (New York: The Modern Library, 1929), 422. 
religious fear, religious love, religious awe, religious joy, and so forth. But religious love is only man's natural love directed to a religious object.. ${ }^{430}$ Thus, religious fear is natural fear directed at a religious image of divine retribution; religious joy is the natural joy one might feel at receiving a gift, but directed at the perception of God's grace in one's life. These religious emotions must be distinguished from mystical experiences, for, as we saw earlier, James claims that mystical feelings serve as the ground and impetus for religious ideas, whereas the religious ideas (God's grace, divine retribution, etc.) serve as the ground for religious emotions. On these accounts, mystical feelings have a logical priority to religious concepts, symbols, and doctrines. Mystical wonder provides the impetus for the creation of religious myths, doctrines, and worldviews.

In his recent work, Mark Wynn develops this theme of the relationship between mystical feeling and religious understanding with the aid of contemporary developments in the philosophy of emotion. ${ }^{431}$ Wynn draws on various contemporary philosophical models of the emotions in order to establish the relationship between emotion and religious understanding. Given that, according to some of these models, certain intellectual content is not otherwise available except through the emotional experience, Wynn argues that feeling is not just constructive, but indispensable to religious understanding. While the various models differ in important respects, Wynn maintains that each can contribute to an overarching account of the relationship between feeling and religious understanding.

One such model is based on the work of John Deigh who argues that the emotions can be thought of as pre-conceptual forms of sensibility. Deigh distinguishes between

\footnotetext{
${ }^{430}$ William James, The Varieties of Religious Experience (Glasgow: Collins, 1960), 47.

${ }^{431}$ Mark Wynn, Emotional Experience and Religious Understanding: Integrating Perception, Conception, and Feeling (Cambridge: Cambridge University Press, 2005), xi.
} 
sensibility of differences from the ability of conceptual predication. Sensibility involves being able to detect properties and discriminate those things that have the property from those that do not, while conceptual predication involves being able to grasp general concepts and use them in propositional thought. For example, beagles are able to detect the smell of rabbit and discriminate those things that have it from those that do not, even though they lack the concept of rabbit and the ability to locate it in a system of propositional thought. ${ }^{432}$ Deigh then argues that sensibility is sometimes achieved through the emotions. For instance, the emotion of fear is the perception of an object's scariness, which is distinct from predicating the dangerousness of the object. On Wynn's interpretation of this model, the emotions are an immediate (non-conceptual) apprehension of some quality or a non-conceptual grasp of the world's character. However, these pre-conceptual emotions can then be shaped and educated by conceptual thought. For instance, Deigh notes that children begin to acquire the concept of the dangerous and can then distinguish the dangerous from what is sensibly scary. This conceptual ability often weakens the impact of the sensory phenomena. For example, a child with the ability to distinguish the harmful from the perceptually scary can recognize that the movie, while perceptually scary, is not harmful or dangerous and this will weaken the emotional impact of the film. So, the child's emotional susceptibilities change with this conceptual ability. ${ }^{433}$ However, as any fan of horror films knows, this conceptual ability may shape our emotional responses, but it does not always deaden them. Thus, Wynn suggests that in addition to the 'primitive' non-conceptual emotions and the conceptual temper of these emotions, there are also cases where an object can

432 John Deigh, "Cognitivism in the Theory of Emotions," Ethics 104 (1994), 840.
433 John Deigh, "Cognitivism in the Theory of Emotions," Ethics 104 (1994), 853. 
continue to excite perceptual-like response, but where this response is permeated with a conceptually informed understanding. ${ }^{434}$ Wynn then applies this model of the emotions as pre-conceptual forms of sensation to religious understanding. "Perhaps there are certain primal, affectively toned responses to the world which can be taken up into larger affective complexes which are structured by concepts and by the work of the imagination; and perhaps it is in this way that affects can contribute to an affectively toned perception of God." ${ }^{, 435}$

Next, Wynn develops a second model based on Peter Goldie's understanding of emotion. Goldie gives an example of someone who, having fallen on ice, may come to think of the dangerousness of the ice in a new, emotionally relevant way. Goldie observes that this new understanding is not simply the old understanding with a feeling added on. Rather, the whole way of being aware of the ice changes, even if this awareness cannot be articulated in words. ${ }^{436}$ Like Deigh, Goldie insists that emotional experiences have content beyond propositional content. Additionally, for Goldie, the emotions are not responses of concern toward perceptual or conceptual content such that the new fear of ice is a response to a new understanding. Rather the fear is itself a new understanding. Wynn then relates this model to Deigh's account. On Deigh's model, emotions can involve an initial, concept-independent affective response which is then infused with conceptual thoughts to produce an affectively toned awareness of the world. Goldie's model works in the reverse direction. For Goldie, feeling builds non-conceptual

\footnotetext{
434 Mark Wynn, Emotional Experience and Religious Understanding: Integrating Perception, Conception, and Feeling (Cambridge: Cambridge University Press, 2005), 95.

435 Mark Wynn, Emotional Experience and Religious Understanding: Integrating Perception, Conception, and Feeling (Cambridge: Cambridge University Press, 2005), 97.

${ }^{436}$ Peter Goldie, The Emotions: A Philosophical Exploration (Oxford: Oxford University Press, 2000), 5960.
} 
content onto a previously achieved conceptual understanding. This is not to suggest that there are two understandings, one conceptual and one non-conceptual, running alongside each other. Rather, the two form one unitary understanding. There is an initial conceptual understanding of the world which the emotions build upon to allow for a new and deeper appreciation. In his example, the feeling allows for a deepening understanding of the dangers of the ice. ${ }^{437}$ On Deigh's model, feeling is penetrated by conceptual understanding. In Goldie's model, conceptual understanding is penetrated by feeling.

With these two models in place, Wynn combines them to build on his view regarding the relationship between feeling and religious understanding. "In the style of [Rudolf] Otto, we can say that a certain kind of religious understanding is available only in affective experience. ... [This] primitive affective responsiveness . . . can help generate new doctrinal reflections, which in turn can help to produce new possibilities of religious feelings, and so on... . The spiral may also involve feeling, which has its own content, being penetrated by discursive thought (following Deigh's model) and feeling taking further (while remaining infused with) the understanding achieved in discursive or doctrinal thought (as Goldie proposes). ${ }^{, 438}$ Wynn admits that, due to intrinsic features of the subject matter, the Deigh-Goldie model is somewhat messy, ${ }^{439}$ but I think he has something like the following account in mind. First, a certain kind of non-conceptual feeling is explanatorily fundamental to religious understanding. Wynn explicitly notes

\footnotetext{
437 Mark Wynn, Emotional Experience and Religious Understanding: Integrating Perception, Conception, and Feeling (Cambridge: Cambridge University Press, 2005), 98-9.

${ }^{438}$ Mark Wynn, Emotional Experience and Religious Understanding: Integrating Perception, Conception, and Feeling (Cambridge: Cambridge University Press, 2005), 133.

${ }^{439}$ Mark Wynn, Emotional Experience and Religious Understanding: Integrating Perception, Conception, and Feeling (Cambridge: Cambridge University Press, 2005), 147.
} 
that if it were not for this non-conceptual religious feeling, religious movements and doctrines would not have developed. ${ }^{440}$ I take it that Deigh's distinction between the ability to be sensible of differences from the ability of conceptual predication explains how such non-conceptual feeling is possible, even if it often later becomes shaped and controlled by conceptual thought. It allows for, as Wynn puts it, "the possibility of a 'primitive' affectively toned sense of God." ${ }^{441}$ Goldie's model is designed to show how such non-conceptual feeling can deepen pre-existing conceptual thoughts. It "allows for the possibility that feeling may be infused by prior doctrinal commitments while building upon and deepening those commitments." ${ }^{442}$ For Wynn, the emotions as perceptions of value can contribute to a religious epistemology, for while they are non-conceptual, they are not non-cognitive if we understand cognition broadly to include perceptual-like content in addition to propositional content.

Wynn draws on two further models of the emotions to contribute to this account of the relationship between feeling and religious understanding. However, the second two, like Aquinas, stress the conative aspect of emotion. First, Wynn turns toward Ronald de Sousa's view of the emotions as constituting patterns of salience. De Sousa does not view the emotions as particular modes of perception or understanding, but as a framework for cognitions. In this sense, they are like Kuhn's notion of scientific paradigms. De Sousa explains that "paying attention to certain things is a source of reasons but comes before them. Similarly, scientific paradigms . . . are better at

\footnotetext{
440 Mark Wynn, Emotional Experience and Religious Understanding: Integrating Perception, Conception, and Feeling (Cambridge: Cambridge University Press, 2005), 147.

${ }^{441}$ Mark Wynn, Emotional Experience and Religious Understanding: Integrating Perception, Conception, and Feeling (Cambridge: Cambridge University Press, 2005), 148.

442 Mark Wynn, Emotional Experience and Religious Understanding: Integrating Perception, Conception, and Feeling (Cambridge: Cambridge University Press, 2005), 148.
} 
stimulating research than at finding compelling and fair reasons for their own adoption. They are too 'deep' for that, too unlike specific, easily formulated beliefs." ${ }^{443} \mathrm{De}$ Sousa's point is that the emotions, like paradigms, set the agenda for our thinking by fixing our concerns and interests. They make certain features of our experience more prominent and salient, giving these features an import that they would have otherwise lacked. Given the amount of information we receive in our experience of the world, we need some way to direct our attention, and the emotions provide this direction, for they, as Wynn explains, "constitute patterns of salience, lighting up some matters as deserving attention and leaving others at the periphery of our awareness."

Applying this to religious life, Wynn suggests that by setting the agenda for our thinking, the emotions can pave the way for the formation of certain kinds of religious understanding. For example, pre-conceptual religious feelings of the kind identified on Deigh's model shapes and sustain discursive religious reflection. ${ }^{445}$ Wynn draws on the work of French philosopher and historian Pierre Hadot to illustrate this point. Hadot is famous for arguing that ancient philosophy was not "philosophical discourse" or abstract theories about the world, but spiritual ways of life designed to transform the student. Instead of offering an abstract metaphysical view from which an ethic is derived, Hadot suggests the reverse was the case in ancient philosophy. The metaphysics is created in order to justify the existential attitude. But the metaphysical discourse alone is not the philosophy, but simply one element of it and an element that is secondary to and derived

\footnotetext{
443 Ronald de Sousa, "The Rationality of Emotions," in Explaining Emotions, ed. Amelie Rorty (Berkeley, CA: University of California Press, 1980), 139.

${ }^{444}$ Mark Wynn, Emotional Experience and Religious Understanding: Integrating Perception, Conception, and Feeling (Cambridge: Cambridge University Press, 2005), 104.

${ }^{445}$ Mark Wynn, Emotional Experience and Religious Understanding: Integrating Perception, Conception, and Feeling (Cambridge: Cambridge University Press, 2005), 105-6.
} 
from the more basic attitude toward life. ${ }^{446}$ According to Hadot, Epicureanism represented the attitude of relaxation, serenity, and the joy of existing, while Stoicism exemplified a feeling of tension, duty, and moral consciousness. Their respective metaphysics were created to justify this basic attitude. For example, the Epicurean doctrine that the gods are indifferent to human affairs justifies the attitude of serenity, since it implies that we need not fear their capricious punishments. On Wynn's interpretation, Hadot is suggesting we can have an intuitive, pre-theoretical affective appreciation of the kind of life that befits a human being, which can then be articulated in and reinforced by a religious worldview.

Building on his theme of feeling having priority over religious conceptualization, Wynn seems to be suggesting the de Sousa's model offers a way of accounting for how religious doctrines both get off and stay off the ground, so to speak. The pre-conceptual feelings set the agenda for religious and spiritual reflection. "And in this way," writes Wynn, "an affective state may propel a person quite properly to think about certain issues, and to examine those issues in the light of certain concerns, and thereby arrive at one kind of worldview rather than another. ${ }^{, 447}$ Wynn recognizes that this way of accounting for religious understanding might seem like a kind of wish fulfillment. The emotional paradigms serve as a kind of template in terms of which experience is construed. He notes that "a pervasive interpretive strategy of this kind may leave a person locked in an illusory world, unable to see the force of genuine counter-evidence, because of their predisposition to read the evidence in ways that conform to their prior

\footnotetext{
${ }^{446}$ Arnold Davidson, "Introduction," in Philosophy as a Way of Life: Spiritual Exercises from Socrates to Foucault, by Pierre Hadot, trans. Michael Chase (Oxford: Blackwell, 1995), 30-1.

${ }^{447}$ Mark Wynn, Emotional Experience and Religious Understanding: Integrating Perception, Conception, and Feeling (Cambridge: Cambridge University Press, 2005), 136.
} 
assumptions." ${ }^{448}$ But he argues that while it might be tempting to set aside the existential attitudes and "approach the world free from any overarching preconception of its sense," ${ }^{449}$ this is neither psychologically possible nor practically rational.

Psychologically, the pre-conceptual existential attitudes are too deeply engrained to set aside. Additionally, given that according to most religious worldviews the religious object is beyond the comprehension of the human mind and is intimately wrapped up in human concern, an attempt to evaluate religious worldviews from a detached perspective is, as John Cottingham notes, "to evade them. A different strategy, a strategy of involvement, . . . is required by the nature of the material." 450

Wynn's final model is derived from Geoffrey Madell's work on emotion and music. Arguing that music can arouse emotions (as opposed to objectless moods), Madell writes that "hearing the dominant seventh evokes a desire, and sometimes something akin to a longing, for its resolution. That is a state of consciousness directed to an intentional object; it is also an affective state of consciousness. . . . It is a mode of 'feeling towards' its intentional object."451 On this view, the object of the emotional tension upon hearing a dominant seventh chord is the resolution on the tonic. But here the intentionality is primarily conative. The mind is cast forward in desire toward an anticipated resolution. Applying this to a religious context, Wynn suggests that such longings and desires point to whatever it would take to satisfy them. "If so, this provides

\footnotetext{
448 Mark Wynn, Emotional Experience and Religious Understanding: Integrating Perception, Conception, and Feeling (Cambridge: Cambridge University Press, 2005), 137.

449 Mark Wynn, Emotional Experience and Religious Understanding: Integrating Perception, Conception, and Feeling (Cambridge: Cambridge University Press, 2005), 137.

450 John Cottingham, The Spiritual Dimension: Religion, Philosophy and Human Value (Cambridge: Cambridge University Press, 2005), 12.

451 Geoffrey Madell, "What Music Teaches About Emotion,” Philosophy 71 (1996): 76.
} 
a further way in which an understanding of God may be embedded in feeling. $" 452$

To take stock, Wynn offers an account of emotional feeling as a mode of value perception and then considers various ways in which mystical feelings relate to religious understanding. Wynn is in agreement with Schleiermacher, Otto, and James that mystical feelings are the grounds of religious conceptualization. As a mode of value perception, Wynn argues that [on the Deigh-Goldie model] such feelings can carry religious import. Additionally, while such feelings themselves are non-discursive, they may serve to direct the development of discursive religious understanding [on the de Sousa model]. Finally [following Madell's model], they may point toward the divine as an object of longing.

While I do not always agree with the details of each of Wynn's models, I can grant his broader point that mystical feelings such as the wonder at the existence of the world provide the impetus for the creation of religious imagination and thought. However, the priority of mystical feeling should only be understood as a logical priority rather than a practical priority. It is not the case, for instance, that individuals create religious worldviews wholesale out the promoting of mystical feelings. While religion may have historically developed out of mystical wonder and the like, as a practical matter, people are generally born into religious communities with pre-existing traditional symbols, beliefs, and practices and become fluent in the network meaning of these inherited symbols long before they have transcendent experiences. For instance, Neville writes that "childhood vests one with a host of . . symbols of religious matters. These symbols are picked up from the media, from school, perhaps from participation in a religious

\footnotetext{
452 Mark Wynn, Emotional Experience and Religious Understanding: Integrating Perception, Conception, and Feeling (Cambridge: Cambridge University Press, 2005), 143.
} 
community, and from friends who have their own religious communities. ${ }^{\text {453 }}$ One often becomes acquainted with the network meaning of religious symbols to some degree in community and only later has an experience that, as Neville phases it, "shocks the person suddenly to see the limits, the particularity, the finiteness of the life-world"454 (content meaning). Neville notes that there is a difference between simply interpreting one's life within the play of religious symbols - a merely network understanding of the symbols typically learned in religious community and practice — and using the symbols to engage the divine. Wynn may be correct that mystical feelings are logically prior to religious symbols and doctrines such that the symbols and doctrines are created in response to such mystical feelings. But Neville reminds us that the symbols are often practically prior to mystical feeling.

Given the symbolic character of the object of religious emotions, these religious emotions can be transformed into mystical feelings once it is grasped that this particular object or concept symbolizes that which lies beyond all finite particularities. A child or hopelessly naïve believer may believe that God really is an old man with a white beard seated on a throne (or whatever else the infinite is symbolized as in one's culture). However, this image, or an image of Christ dying on a cross, or of Durga wielding her arms, or a cathedral pointing one's gaze skyward can suddenly evoke a sense of one's limits in contrast to the infinite. Religious symbols are expressions of mystical feeling, but they are also a means by which such feelings are evoked. But without an initial form of concern toward the symbol itself (perhaps in the form of gratitude or compassion), the symbol could not evoke such a response.

\footnotetext{
${ }^{453}$ Robert C. Neville, The Truth of Broken Symbols, 163.

${ }^{454}$ Robert C. Neville, The Truth of Broken Symbols, 163.
} 
There are, for example, instances in which a symbol cannot work because, due to contingent circumstances of the interpreter, it cannot elicit an appropriate form of concern. The effectiveness of symbols is relative to the spiritual state and stage of the interpreter. For example, Neville notes that for the Romans in antiquity, Jesus was dressed as a philosopher. For the seventeenth century Dutch, the disciples were burghers. For many white Americans, Jesus is blond and dressed in a choir robe. While none of these presentations are historically accurate, it would have been impossible for these groups to relate to a wandering, Aramaic-speaking, Galilean teacher. ${ }^{455}$ Of course, a person's devotional state can grow in order to accommodate a more historically accurate image, but, in a devotional context, the symbol must meet the devotee where they are and certain symbols cannot be effective given one's contingent circumstances. A historically accurate representation of Jesus would not be able to transform someone who does not speak Aramaic. On the other extreme, a white, blond, blue-eyed Jesus is likely to strike many more sophisticated believers as false. The Calvinist symbol of total depravity will likely not be able to effectively transform a victim of sexual abuse who sees guilt in only psychological terms. If a symbol cannot evoke a religious emotion/concern, it cannot transform this concern to mystical feeling.

\section{Religious Practice and Religious Emotion}

The religious life, however, is not simply about evoking mystical feelings or experiences. Huston Smith famously said in an interview that "the important thing [in

\footnotetext{
455 Robert Cummings Neville, The Truth of Broken Symbols (Albany, NY: State University of New York Press, 1996), 254-5.
} 
the spiritual life] is not altered states, but altered traits of life."456 I cannot argue for such a position here, but it is an important aspect of the working definition of religion I offered in chapter two. According to this definition, religion as a set of interrelated and traditional human practices performed in response to perceived ultimacy with the end of individual, social, and/or global transformation. A part of this transformation involves approaching the saintly ideals discussed in chapter four. This account of religious emotions can also shed light on the relationship between religious practice and religious emotion in this process of transformation.

It will be helpful at this point to remind the reader of the devotional context in which symbols that serve as objects of religious emotions are situated. Symbols serve different purposes in different contexts and whether or not a particular symbol will be effective is relative to, in part, the context. The devotional context "is dominated by the purposes of conforming the soul or self to the religious object [ultimacy in the anthropological sense $]^{457}$ in whatever respects the symbols can represent the object."458 Given the purpose in this context is not to come to a theoretical understanding of the divine, as it is in the theological context, the symbols can be much more fantastic. One need not believe in a literal Inferno for Dante's narrative to awaken one to moral deficiencies in their life. As a result of this clear difference in contexts, the way in which symbols are evaluated vary from context to context. The criteria by which symbols are evaluated are in terms of whether they serve their contextual purpose. Neville explains that "because the nature of devotion is to be radically transformative, the [symbolic]

\footnotetext{
456 Huston Smith, The Way Things Are: Conversations with Huston Smith on the Spiritual Life, ed. Phil Cousineau (Berkeley: University of California Press, 2003), 227.

457 See the beginning of chapter two for what I mean by the anthropological sense of ultimacy.

458 Robert C. Neville, Religion in Late Modernity, 60.
} 
carryover is something like the realization of the divine in the person. But of course different symbol systems express this differently, both regarding the nature of the divine and the kind of human state thought to realize this." ${ }^{459}$ For Neville, part of what it means for a symbol to be "true" in the devotional context is that it helps conform the interpreter to the transformative end.

With this context of the object of religious emotions in mind, we can begin to make some initial observations about the relationship between religious practice and religious understanding. Echoing a point I made in the previous section, there is a sense in which religious practice is prior to religious understanding (and therefore religious emotion). Grasping the network meaning of religious symbols occurs through participation in religious community. Again, I do not mean that it necessarily requires involvement in a religious institution, but simply that religious symbols are socially acquired and culturally embedded. Like any language, fluency in symbols of ultimacy requires social participation. But while having a grasp of the network meaning of religious symbols is necessary in order for such symbols to be appropriately transformative, it is not sufficient.

To see this, we need to develop the concept of religious practice a bit more, which I would like to do by drawing on the work on Alasdair MacIntyre. For MacIntryre, practice is a technical term referring to "any coherent and complex form of socially established cooperative human activity through which goods internal to that form of activity are realized in the course of trying to achieve those standards of excellence which are appropriate to, and partially definitive of, that form of activity, which the results that

\footnotetext{
${ }^{459}$ Robert Cummings Neville, The Truth of Broken Symbols (Albany, NY: State University of New York Press, 1996), 252-3.
} 
human powers to achieve excellence, and human conceptions of the ends and goods involved, are systematically extended." ${ }^{460}$ I want to suggest that we can understand the religious life as a practice in this sense. By "internal goods," MacIntrye means goods that can only be identified, recognized, and achieved by the experience of participating in the practice in question. To clarify, MacIntyre offers his famous example of the practice of chess and the chess-playing child.

Consider the example of a highly intelligent seven-year old child whom I wish to teach to play chess, although the child has no particular desire to learn the game. The child does however have a very strong desire for candy and little chance of obtaining it. I therefore tell the child that if the child will play chess with me once a week I will give the child 50 cents worth of candy; moreover I tell the child that I will always play in such a way that it will be difficult, but not impossible, for the child to win and that, if the child wins, the child will receive an extra 50 cents worth of candy. Thus motivated the child plays and plays to win. Notice however that, so long as it is the candy alone which provides the child with a good reason for playing chess, the child has no reason not to cheat and every reason to cheat, provided he or she can do so successfully. But, so we may hope, there will come a time when the child will find in those goods specific to chess, in the achievement of a certain highly particular kind of analytical skill, strategic imagination and competitive intensity, a new set of reasons, reason now not just for winning on a particular occasion, but for trying to excel in whatever way the game of chess demands. Now if the child cheats, he or she will be defeating not me, but himself or herself. ${ }^{461}$

Notice that the goods internal to chess (acquisition of particular kinds of skills and the experience of particular types of appreciative enjoyments), as opposed to the external good of candy, can only be understood and achieved though participation in the game.

But participation in the game does not guarantee that the internal goods will be achieved. Here we can make an analogy with religious practice. One may participate in the symbolic rituals of a particular tradition, without ever even appreciating the good of the saintly ideal within that tradition. One may even have a terrific grasp of the network

${ }^{460}$ Alasdair MacIntyre, After Virtue (Notre Dame, IN: Notre Dame University Press, 2007), 187.
${ }^{461}$ Alasdair MacIntyre, After Virtue (Notre Dame, IN: Notre Dame University Press, 2007), 188. 
meaning of the symbols involved and know, for example, that the bread and wine refer to the body and blood of Christ, which in turn refers to the God's grace, etc., without ever seeing the value of having their concerns conformed to the ideal end of the tradition, much like the child may know how to move the pieces around board, without ever gaining an appreciation for the game of chess. There may come a time when the participant in the religious tradition does have their emotional concerns shaped by the symbols toward the religious end, but much like no one fully appreciates, much less acquires, the goods internal to chess before they play it, so religious practice comes prior to seeing the value of religious practice.

This raises an important epistemological point. Given that the religious life is primarily about embarking on a path of self-transformation, it is not practically rational to expect impartial, rational grounds for participating in the religious life. For Cottingham, this primacy of praxis explains the "strange sense of distortion, or wrong focus, which one has when confronted with many of the classic debates on philosophy of religion in the academic literature - the sense that despite the grandeur and apparent centrality of the issues raised, they do not capture what is at the heart of the religious enterprise." ${ }^{462}$ Cottingham's point is not simply that we learn religious language (network meaning) through participation in a religious community, a point that seems obvious enough. Rather it is that it is in the very nature of religious understanding (content meaning) that it characteristically stems from practical involvement rather than rational analysis. The religious life requires, as Cottingham phrases it, a "strategy of involvement."463

\footnotetext{
462 John Cottingham, The Spiritual Dimension: Religion, Philosophy and Human Value (Cambridge: Cambridge University Press, 2005), 5.

463 John Cottingham, The Spiritual Dimension: Religion, Philosophy and Human Value (Cambridge: Cambridge University Press, 2005), 12.
} 
The notion that it is not practically rational to expect impartial reasons to serve as epistemic grounds for religious participation and that those who lack participatory experience are inadequate judges should not be construed as implying support for an uncritical religious fideism. To illustrate this, we can draw on MacIntryre's concept of a narrative quest. MacIntyre argues for a narrative concept of selfhood such that "like characters in a fictional narrative we do not know what will happen next, but nonetheless our lives have a certain form which projects itself towards our future. Thus the narrative which we live out has both an unpredictable and a partially teleological character." ${ }^{464}$ Moreover, if this narrative is to be intelligible, it must be conceived of in terms of some ultimate telos. "When someone complains ... that his or her life is meaningless, he or she is often and perhaps characteristically complaining the narrative of their life has become unintelligible to them, that it lacks any point, any movement towards a climax or a telos. ${ }^{\$ 65}$ Thus, MacIntyre distinguishes between particular internal goods recognized and achieved through various practices and "a telos which transcends the limited goods of practices by constituting the good of a whole human life.,"466 This quest for an ultimate telos provides a unity to the narrative of life and it is precisely at this level of the good, of ultimacy, that we meet the religious life in its various forms. MacIntrye observes two important characteristics of this final telos. First, this telos must be at least partially determinate if it is to serve as the final goal of one's narrative life. However, and secondly, the final telos is never fully determinate. The life in pursuit of some final telos "is not at all that of a search for something already adequately characterized, as

\footnotetext{
464 Alasdair MacIntyre, After Virtue (Notre Dame, IN: Notre Dame University Press, 2007), 216.

465 Alasdair MacIntyre, After Virtue (Notre Dame, IN: Notre Dame University Press, 2007), 217.

466 Alasdair MacIntyre, After Virtue (Notre Dame, IN: Notre Dame University Press, 2007), 203.
} 
miners search for gold of geologist for oil. . . A quest is always an education both as to the character of that which is sought and in self-knowledge."467 Precisely because the final telos is never fully determinate, MacIntyre emphasizes the importance of rational criticism within traditions. "When a tradition is in good order it is always partially constituted by an argument about the goods the pursuit of which gives that tradition its particular point and purpose. . . A living tradition then is an historically extended, socially embodied argument, and an argument precisely in part about the goods which constitute that tradition."

Framing the religious life as a quest for some good where the good and the self in pursuit of that good are never fully understood can illuminate the relationship between religious practice, religious emotion, and religious understanding. I grant Cottingham's and Neville's basic point regarding the primacy of practice and the fact that network understanding of religious symbols is prior to the experience of the divine through those symbols. However, religious emotions, when properly ordered in terms of the saintly ideals discussed in the previous two chapters, can help sustain religious practice. MacIntryre notes a similar point in his discussion of the virtues, which are, in part, a proper ordering of the emotions. "The virtues therefore are to be understood as those dispositions which will not only sustain practices and enable us to achieve the goods internal to practices, but which will also sustain us in the relevant kind of quest for the good, by enabling us to overcome the harms, dangers, temptations and distractions which we encounter, and which will furnish us with increasing self-knowledge and increasing

467 Alasdair MacIntyre, After Virtue (Notre Dame, IN: Notre Dame University Press, 2007), 219.
468 Alasdair MacIntyre, After Virtue (Notre Dame, IN: Notre Dame University Press, 2007), 222. 
knowledge of the good. ${ }^{\circ 69}$ We saw in the previous two chapters how religious symbols help engender certain transformations of the heart. The point I want to make here is that these emotional responses - these transformations of the heart - then serve to sustain further engagements with religious symbols designed to produce an experiential awareness of the divine. For example, a Muslim child may participate in the daily prayers without any understanding of the goods internal to that practice. He or she may simply participate in order to achieve certain external goods, perhaps in search of some reward or the avoidance of punishment from his or her parents. However, there may come a time when the practice of repetitive prayer and bodily prostrations, along with a whole host of other symbolic practices, engender some experience of dependency and an emotional response of pious submission. This transformation of the heart can then begin to sustain further devotional practices, which, in turn, results in further experiential understanding and transformation. The transformation of the Muslim's cares, concerns, and interests are always mediated through various symbolic engagements, but also serve to support further symbolic engagement, and, thus, further transformation.

Mark Wynn attempted to show that the emotions carry unique cognitive evaluative content, a move he found necessary to secure an important epistemic contribution of the emotions in the religious life. While the model religious emotions I have offered would not suggest that the emotions themselves carry cognitive content, it still provides an important epistemic role to the emotions. Religious emotions sustain the religious practices which are the precondition for deepening religious understanding. Just as the detached scrutiny of the scientist would be inappropriate when applied to personal

${ }^{469}$ Alasdair MacIntyre, After Virtue (Notre Dame, IN: Notre Dame University Press, 2007), 219. 
relationships, so the religious life requires a "strategy of involvement" can only be maintained in concert with the emotions. Religious emotions sustain the religious practices that are so fundamental to the transformation at the heart of the religious and spiritual life.

Understanding the religious life in this way has the added advantage of squaring well with Aquinas's account of faith. Aquinas writes that "believers assent to what they believe not because their minds see it to be true, either directly or by reduction to selfevident premises, but because their wills command their minds to assent. And this is ... because believing is willed as a good." 471 For Aquinas, in cases of faith, the mind does not grasp the object. Paul MacDonald explains that according to Aquinas, the will moves the intellect to assent to the propositions of faith "not as an object to be understood but as good (as of yet not possessed) to be desired," ${ }^{, 42}$ and so in this sense the intellect does not fully understand or "see" what it is that it assents to. The primary purpose of the religious life for Aquinas is not to gain a correct worldview, but to be transformed. The "infused virtues [faith, hope, and love] dispose man in a higher manner and towards a higher end, and consequently in relation to some higher nature, i.e. in relation to a participation of the Divine Nature."

This chapter has presented the relationship between mystical feelings, religious understanding, religious emotions, and religious practice. Mystical feelings must be distinguished from religious emotions on the basis that the object of mystical feelings is

\footnotetext{
470 John Cottingham, The Spiritual Dimension: Religion, Philosophy and Human Value (Cambridge: Cambridge University Press, 2005), 12.

471 Thomas Aquinas, Summa Theologiae II-II, q. 5, a. 1 trans. Timothy McDermott.

472 Paul A. MacDonald, Jr., “A Realist Epistemology of Faith,” Religious Studies 41 (2005): 374.

473 Thomas Aquinas, Summa Theologiae I-II, q. 110, a. 3, trans. Fathers of the English Dominican Province (New York: Benzinger Bros., 1948).
} 
not a religious symbol, but that which transcends finite particularities. Mark Wynn shows how mystical feelings can form the basis of religious symbols. The account of religious emotion offered in this project contributes to this discussion by showing that this priority of mystical feeling is not a practical priority, for it is often through such symbols that religious seekers engage with that which transcends all finite particularities. Given the symbolic nature of the objects of religious emotions, such emotions can be transformed into mystical feeling. Finally, I further developed John Cottinghams's position regarding the primacy of praxis. It is through practical participation in the religious life that one acquires both a network understanding of religious symbols and an increasing awareness of and appreciation for the goods internal to religious practice. 


\section{CONCLUSION}

The underlying thesis of this dissertation has been that my model of religious emotions can help explain and illuminate the nature of religious emotions and their integration with religious understanding and practice. I have shown that the Thomistic theory of emotion is robust and nuanced enough to account for the facts that any good theory of emotion needs to explain. By conceiving of the emotions as psychosomatic forms of transformational concern, one is able to account for the fact that emotions are intentional — that they take "objects" and that the emotions are distinguished based on the type of object they take. The emphasis on the conative aspect of emotion also allows one to account for the fact that emotions are paradigmatically motivational. They move us to tears, to laughter, to contemplation, to action. Aquinas also explains how we have some, but not full, voluntary control over our emotions. The fact that emotions come in degrees of intensity can be explain both in terms of the formal appetitive aspect and the material feeling aspect. Aquinas also accounts for the fact that our emotions are subject to rational assessment.

In addition to being a comprehensive account of the passions generally, Aquinas's taxonomy of basic emotions, while perhaps not ontologically grounded or the only way of organizing the emotions, provides an excellent framework for seeing connections between various religious emotions and for comparing common and distinctive emotional patterns both within and across religious boundaries. Aquinas's organization of the 
passions of attraction (love, longing, joy, hope, and despair) allows one to see the commonalities in the emotional lives of the ideal saints (the model of the perfection of impulses of the heart) across religious traditions. For example, one can detect a common emotional dialectical pattern, an oscillation of religious joy and religious longing, across many religious traditions. Moreover, this pattern often transforms into a similar oscillation of religious hope and despair. Aquinas's close attention to the relationship between various emotions helps bring these connections to the surface.

In addition to illuminating commonalities in the religious versions of ideal saints, the theory of religious emotions also brings distinctive features of various saintly ideals to light. For example, we saw certain traditions valuing the hatred of whatever is perceived as unsuitable to the proper conformity with perceived ultimacy (sin, attachments, etc.), while the notion of a virtuous hatred is foreign to other saintly ideals. We saw examples of religious disgust being used as a means to quite different religious ends. Concerning sorrow, the Calvinist's guilt (a form of sorrow) weakens the will to the end of submission to a sovereign ontological Other. The sorrow of the Christian mystic, on the other hand, is a necessary step toward union with an ontological Other.

Viewing religious emotions as emotions that have religious symbols as their objects allows one to resist the temptation to limit religious emotions to some distinctive experience. On the framework presented here, any emotion can be religious. While mystical feelings (which are often taken to be paradigmatic religious emotions) are of great importance to the religious life, limiting one's attention to these experiences fails to do full justice to the role of emotions in religious life. It was also necessary to have a theory of religious symbolism as nuanced as Neville's to make important distinctions. 
For example, the triadic structure of Neville's account of interpretation as involving not just a signifier and signified, but also an interpreter, allows one to account for why the feeling of wonder at the craftsmanship of the representations of the gods by a tourist in a Japanese temple is not (necessarily) a religious wonder. If the symbol is not interpreted in a devotional context—in the context of conforming one's self to ultimacy—it fails to be a religious emotion because the gods fail to signify one's ultimate concern. Also, Neville's distinction between the theological and devotional context, as well has his distinction between iconic and indexical symbolism, allows us to see how extremely fantastic images_-images of devil, hells, lush paradises, etc.—can nevertheless symbolize the divine and serve as objects of religious emotions.

Finally, this account of religious emotions also provided a way to explore the relationship between emotions, cognition, and practice in the religious life. It allowed for the important distinction between mystical feelings and religious emotions, and to see how religious emotions sustain religious practices at the heart of the religious path of transformation and can themselves be transformed into mystical feelings given the symbolic nature of their object. The relationship between emotions, cognition, and practice also has important epistemological significance. Given the fact that religious practice characteristically precedes religious understanding and that the goal of the religious quest, while never fully determinate, comes to be appreciated through religious practice, it is not practically rational to expect impartial justification for religious worldviews prior to religious participation. Religious emotions, therefore, provide an important epistemic role in that they motivate and sustain the practices so fundamental to religious understanding. Emotions can move the religious person to activities of prayer, 
prostration, giving, weeping, pilgrimage, confession, meditation, etc. It is through such practices that the religious seeker begins to realize the goods internal such practices.

This thesis has broad significance for the phenomenological/comparative study of religion. David Morgan notes that "the academic study of religion in the modern West has been shaped by the idea that a religion is what someone believes, which consists of a discrete, subjective experience of assent to propositions concerning the origin of the cosmos, the nature of humanity, the existence of deities, or the purpose of life." 474 The problem with this tendency is that it reduces religion to a body of assertions demanding assent. Morgan argues that in order for scholars to compare accounts of different religions in a way that allows for both their similarities and differences to surface, religious life must be understood broadly in somatic and material terms. "People report the reality of UFOs, the presence of angels, hearing the voice of God, the power of spirits to work for good or ill, the ability of Quranic text to bestow baraka [blessing], of passages of Torah bundled in a mezuzah to do the same, of the Bible opened randomly to reveal a pertinent scripture verse. Describing these as beliefs in the thin sense of affirmed dogmas fails miserably to help us understand what is happening in the lives of those in which these practices may be observed." 475 In addition to belief, Morgan cites memory, imagination, sensation, emotion, and material objects as important elements of study. In many ways, the study of religious emotions provides an entry point into the study of these more somatic and material elements of the religious

\footnotetext{
${ }^{474}$ David Morgan, "The Matter of Belief," in Religion and Material Culture: The Matter of Belief, ed. David Morgan (New York: Routledge, 2010), 1.

${ }^{475}$ David Morgan, "The Matter of Belief," in Religion and Material Culture: The Matter of Belief, ed. David Morgan (New York: Routledge, 2010), 3.
} 
life. For as we have seen, imaginings, memories, sensations, and material objects serve as symbolic objects of religious emotion. The comparative study of religious emotion is miniscule compared to the attention worldviews and practices receive in academic literature. This project begins to fill this gap in academic research and provides a framework for further research.

Finally, there are further steps one could take with the theory that has been developed in this thesis. The recent renewal of philosophical interest in the emotions has led to much research in ethical and aesthetic emotions. One potential development could be to compare the logic of religious emotions with that of ethical and aesthetic emotions. For example, one might naturally distinguish moral and aesthetic emotions based on the distinction between moral and aesthetic value. For instance, a movie may be aesthetically beautiful but morally corrupting. Thus, one might take aesthetic delight in the sensuous forms of the film, but be disgusted by the violent and immoral content. But whether or not this is an appropriate way of distinguishing moral and aesthetic emotions, it is not clear whether religious emotions can be distinguished from moral and aesthetic emotions in the same way. For it is often the aesthetic quality of religious symbols that give them their symbolic character. Writing on Orthodox icons, David Brown writes that "it is that very lack of realism which ... will enable [the viewer] to acknowledge an immaterial world beyond its own." ${ }^{476}$ This thesis has discussed what makes an emotion a religious emotion, but it still remains to be seen whether an emotion can be both aesthetic and religious—or moral and religious. Given the close interaction between

\footnotetext{
${ }^{476}$ David Brown, God and Enchantment of Place: Reclaiming Human Experience (Oxford: Oxford University Press, 2004), 41.
} 
the moral, aesthetic and religious sphere, this theory might be able inform and be informed by work in these other fields.

There are many ways of approaching the topic of religion and emotion. Neuroscience, social/behavioral sciences, history, theology, and philosophy can all make important contributions to this field. The emotions are constitutive of the religious life and in order to better understand the phenomenon of religion, we need to better understand the emotions and their role in this context. Willem Lemmens and Walter Van Herck note that "the philosophical study of religious emotions has only just begun." ${ }^{477}$ My hope is that this project contributes to this emerging discussion in some small way and helps keep the conversation moving forward.

${ }^{477}$ Willem Lemmens and Walter Van Herck, "Introduction," in Religious Emotions: Some Philosophical Explorations, ed. Willem Lemmens and Walter Van Herck (Cambridge: Cambridge Scholars Publishing, 2008), 10. 


\section{REFERENCES}

Alston, William. Perceiving God: The Epistemology of Religious Experience. Ithaca, NY: Cornell University Press, 1993.

Aristotle. Physics, translated by R. P. Hardie and R. K. Gayle. The Internet Classics Archive. Accessed April 12, 2013. http://classics.mit.edu/Aristotle/physics.3.iii.html

Bedford, Errol. "Emotions.” In The Philosophy of Mind, edited by V. C. Chappell 110126. Englewood Cliffs, NJ: Prentice Hall, 1962.

Ben-Ze'ev, Aaron. The Subtlety of Emotions. Cambridge, MA: Massachusetts Institute of Technology Press, 2000.

Brown, David. God and Enchantment of Place: Reclaiming Human Experience. Oxford: Oxford University Press, 2004.

---. God and Grace of Body: Sacrament in Ordinary. Oxford: Oxford University Press, 2007.

Buddhaghosa, Bhadantácariya. The Path of Purification, translated by Bhikku Náóamoli. Kandy, Sri Lanka: Buddhist Publication Society, 2011.

Carroll, Noel. "Art and the Moral Realm.” In The Blackwell Guide to Aesthetics. Edited by Peter Kivy. Malden, MA: Blackwell Publishing, 2004.

Casey, John. Pagan Virtue: An Essay in Ethics. Oxford: Clarendon Press, 1990.

Cates, Diana Fritz. "The Religious Dimension of Ordinary Human Emotions.” Journal of 
the Society of Christian Ethics 25 (2005): 35-53.

---. Aquinas on the Emotions: A Religious-Ethical Inquiry. Washington D. C.:

Georgetown University Press, 2009.

Cottingham, John. The Spiritual Dimension: Religion, Philosophy, and Human Value.

Cambridge: Cambridge University Press, 2005.

Damasio, Antonio. Descartes' Error: Emotion, Reason, and the Human Brain. New York: Putnam, 1994.

---. Looking for Spinoza: Joy, Sorrow, and the Feeling Brain. Orlando: Harcourt, 2003.

---. Self Comes to Mind: Constructing the Conscious Brain. New York: Pantheon, 2010.

Davidson, Arnold. "Introduction." In Philosophy as a Way of Life: Spiritual Exercises from Socrates to Foucault, by Pierre Hadot, translated by Michael Chase. Oxford: Blackwell, 1995.

Deigh, John. "Cognitivism in the Theory of Emotions.” Ethics 104 (1994): 824-854.

Delaney, Neil. "Romantic Love and Loving Commitment: Articulating a Modern Ideal." American Philosophical Quarterly 33 (1996): 339-356.

Dixon, Thomas. From Passions to Emotions: The Creation of a Secular Psychological Category. Cambridge: Cambridge University Press, 2003.

Dupré, Louis. Religious Mystery and Rational Reflection. Grand Rapids, MI: Wm. B. Eerdmans Publishing Company, 1998.

---. Symbols of the Sacred. Grand Rapids, MI: Wm. B. Eerdmans Publishing Company, 2000.

Eckel, Malcolm David with John J. Thatmanil. "Cooking the Last Fruit of Nihilism: Buddhist Approaches to Ultimate Reality." In Ultimate Realities, edited by Robert 
Cummings Neville, 125-150. Albany, State University of New York Press, 2001.

Edwards, Jonathan. The Religious Affections in Three Parts. Grand Rapids, Michigan: Sovereign Grace Publishers, 1971.

Edwards, Jonathan. Sinners in the Hands of an Angry God. Boston: S. Kneeland and T. Green, 1741.

Elster, Jon. Alchemies of the Mind. Cambridge: Cambridge University Press, 2000.

Fisher, Philip. The Vehement Passions. Princeton and Oxford: Princeton University Press, 2002.

Frankfurt, Harry. "Freedom of the Will and the Concept of a Person." The Journal of Philosophy 68 (1971): 5-20

Fuller, Robert C. Wonder: From Emotion to Spirituality. Chapel Hill: University of North Carolina Press, 2006.

Gade, Anna M. "Islam." In The Oxford Handbook of Religion and Emotion, edited by John Corrigan, 35-50. Oxford: Oxford University Press, 2008.

Gereboff, Joel, Keith Green, Diana Fritz Cates, and Maria Heim. "The Nature of the Beast: Hatred in Cross-Traditional Religious and Philosophical Perspective." Journal of the Society of Christian Ethics 29 (2009): 175-205.

Goldie, Peter. The Emotions. Oxford: Clarendon Press, 2000.

---. "Intellectual Emotions and Religious Emotions." Faith and Philosophy 82 (2011): 93-101.

Green, Keith. "Aquinas on Attachment, Envy, and Hatred in the Summa Theologica." Journal of Religious Ethics 35 (2007): 403-428.

Heidegger, Martin. An Introduction to Metaphysics, translated by Ralph Mannheim. 
Garden City, New York: Anchor Books, 1961.

Helm, Bennett. "Freedom of the Heart." Pacific Philosophical Quarterly 77 (1996): 7187.

Helm, Bennett. "Love.” The Stanford Encyclopedia of Philosophy (Fall 2009 Edition). Edited by Edward N. Zalta, URL = $<$ http://plato.stanford.edu/archives/fall2009/entries/love/>.

Hick, John. An Interpretation of Religion: Human Responses to the Transcendent (New Haven, Yale University Press, 2004.

--- “The Religious Meaning of Life." In The Meaning of Life in the World Religions, edited by Joseph Runzo and Nancy M. Martin, 269-288. Oxford: Oneworld Publications, 2000.

Hjort, Mette and Sue Laver, ed. Emotion and the Arts. Oxford: Oxford University Press, 1997.

James, Susan. Passion and Action: The Emotions in Seventeenth Century Philosophy. Oxford: Clarendon Press, 1997.

James, William. "What is an Emotion?" In What is an Emotion?, edited by Robert C. Solomon, 66-76. New York: Oxford University Press, 2004.

---. The Varieties of Religious Experience: A Study in Human Nature. New York: The Modern Library, 1929.

---. The Varieties of Religious Experience. Glasgow: Collins, 1960.

Järveläinen, Petri. "What are Religious Emotions." In Religious Emotions: Some Philosophical Explorations, edited by Willem Lemmens and Walter Van Herck, 12-26. Cambridge: Cambridge Scholars Publishing, 2008. 
Kalalowski, Leszek. Religion. South Bend: St. Augustine’s Press, 2001.

Kaufman, Peter Ivan. Prayer, Despair, and Drama: Elizabethan Introspection. Urbana: University of Illinois Press, 1996.

Kenny, Anthony. Action, Emotion, and Will. London: Routledge and Kegan-Paul, 1963.

---. Aquinas on Mind. New York: Routledge, 1993.

Kerr, Fergus. Theology After Wittgenstein. Oxford: Oxford University Press, 1986.

King, Peter. "Aquinas on the Emotions." In The Oxford Handbook to Aquinas, edited by Brian Davies and Eleonore Stump 209-226. Englewood Cliffs, NJ: Prentice Hall, 1962.

Koran. Translated by N. J. Dawood. New York: Penguin, 1990.

Lane, Richard. The Cognitive Neuroscience of Emotion. New York: Oxford University Press, 1999.

Leemens, Willem and Walter Van Herck, ed. Religious Emotions: Some Philosophical Explorations. Cambridge: Cambridge Scholars Publishing, 2008.

Lombardo, Nicholas E. The Logic of Desire: Aquinas on Emotion. Washington D. C.: The Catholic University of America Press, 2011.

Lugo, Luis, Director. “'Nones’ on the Rise: One-in-Five Adults Have No Religious Affiliation." The Pew Forum on Religion and Public Life. Washington, D.C.: Pew Research Center, 2012, accessed February 10, 2013, http://www.pewforum.org/uploadedFiles/Topics/Religious_Affiliation/Unaffiliate d/NonesOnTheRise-full.pdf.

Lyons, William, Emotions. Cambridge: Cambridge University Press, 1980.

MacDonald, Paul A. “A Realist Epistemology of Faith.” Religious Studies 41 (2005): 
373-393.

MacIntyre, Alasdair. After Virtue. Notre Dame, IN: Notre Dame University Press, 2007. Madell, Geoffrey. "What Music Teaches About Emotion.” Philosophy 71 (1996): 63-82. Maimonides, Moses. “The Guide for the Perplexed.” In The Jewish Mystical Tradition, translated by Ben Zion Bokser. New York: Pilgrim Press, 1993.

Martin, Nancy M. and Joseph Runzo. "Love.” In The Oxford Handbook of Religion and Emotion, edited by John Corrigan, 310-332. Oxford: Oxford University Press, 2008.

---. "Love and Longing in Hinduism." In The Meaning of Life in the World Religions, edited by Joseph Runzo and Nancy M. Martin, 187-202. Oxford: Oneworld Publications, 2000.

McDaniel, June. "Emotion in Bengali Religious Thought." In Religion and Emotion: Approaches and Interpretations, edited by John Corrigan, 249-270. New York: Oxford University Press, 2004.

Merleau-Ponty, Maurice. "The Spatiality of One’s Own Body and Motility.” In Phenomenology of Perception, 112-170. London: Routledge, 2002.

Milbank, John and Catherine Pickstock. Truth in Aquinas. London and New York: Routledge, 2001.

Miner, Robert. Thomas Aquinas on the Passions: A Study of Summa Theologiae, 1a2ae 22-48. Cambridge: Cambridge University Press, 2011.

Morgan, David. The Sacred Gaze: Religious Visual Culture in Theory and Practice. Berkeley: University of California Press, 2005.

---. "The Matter of Belief." In Religion and Material Culture: The Matter of Belief, 
edited by David Morgan, 1-17. New York: Routledge, 2009.

---, ed. Religion and Material Culture: The Matter of Belief. New York: Routledge, 2009.

Murdoch, Iris. Existentialists and Mystics: Writings on Philosophy and Literature. London: Chatto \& Windus, 1997.

Neville, Robert C. On the Scope and Truth of Theology: Theology as Symbolic

Engagement. New York: T\&T Clark International, 2006.

---. “A Peircean Theory of Religious Interpretation.” In Pragmatism and Religion, edited by Stuart Rosenbaum, 277-302. Urbana and Chicago: University of Illinois, 2003.

---. Religion in Late Modernity. Albany, NY: State University of New York Press, 2002.

---. Soldier, Sage, and Saint. New York: Fordham University Press, 1978.

---. The Truth of Broken Symbols. Albany, NY: State University of New York Press, 1996.

---. Realism in Religion: A Pragmatist's Perspective (Albany, State University of New York Press, 2009).

Neville, Robert C. and Wesley J. Wildman. "Introduction." In Ultimate Realities, edited by Robert C. Neville, 1-8. Albany, NY: State University of New York Press, 2001.

Nietzsche, Friedrich. The Gay Science: With a Prelude in Rhymes and an Appendix of Songs. Translated by Walter Kaufman. New York: Random House, 1974.

Novak, Philip. The World's Wisdom: Sacred Texts of the World's Religions. New York: HarperOne: 1994.

Nussbaum, Martha. The Therapy of Desire. Princeton: Princeton University Press, 1996. 
---. Upheavals of Thought: The Intelligence of Emotions. Cambridge: Cambridge University Press, 2001.

Otto, Rudolf. The Idea of the Holy. Translated by John W. Harvey. London: Oxford University Press, 1950.

Pieper, Josef. Faith, Hope, Love. San Francisco: Ignatius Press, 1997.

Plato. Philebus. Translated by Dorothea Frede. In Plato's Complete Works, edited by John M. Cooper, 398-456. Indianapolis: Hackett Publishing Company, 1997.

Prothero, Stephen. God Is Not One: The Eight Rival Religions That Run the World-and Why Their Difference Matter. New York: HaperOne, 2010.

Riis, Ole and Linda Woodhead. The Sociology of Religious Emotions. Oxford: Oxford University Press, 2011.

Roberts, Robert C. Emotion: An Essay in Aid of Moral Psychology. Cambridge: Cambridge University Press, 2003.

---. "Emotions Research and Religious Experience." In The Oxford Handbook of Religion and Emotion, edited by John Corrigan, 490-506. Oxford: Oxford University Press, 2010.

---. Spiritual Emotions: A Psychology of Christian Virtues. Gran Rapids, MI: Wm. B. Eerdmans Publishing, 2007.

---. "Thomas Aquinas on the Morality of Emotions." History of Philosophy Quarterly 9 (1992): 287-305.

Robinson, Jenefer. Deeper Than Reason. New York: Oxford University Press, 2005. Rorty, Amelie, ed. Explaining Emotions. Berkeley: University of California Press, 1980. Rubin, Julius. "Melancholy." In The Oxford Handbook of Religion and Emotion, edited 
by John Corrigan, 290-309. Oxford: Oxford University Press, 2008.

Rumi, Jelaluddi. “Completely Cooked." In The World's Wisdom: Sacred Texts of the World's Religions, edited by Philip Novak, 326-327. New York: HaperOne, 1994. Santideva. "Sikshasamuccya." In Buddhist Texts Through The Ages, edited by Conze et al, 119-145. New York: Harper \& Row, 1964.

Schleiermacher, Friedrich. The Christian Faith. Translated by H. R. Mackintosh and J. S. Stewart. Edinburg: T. \& T. Clark, 1999.

Schimmel, Solomon. "Education of the Emotions in Jewish Devotional Literature: Anger and Its Control." Journal of Religious Ethics 8 (Fall 1980): 259-276.

Scruton, Roger. Sexual Desire: A Philosophical Investigation. London: Continuum, 2006.

Shneur Zalman of Lyady. "Iggeret haKodesh.” In The Jewish Mystical Tradition, translated by Ben Zion Bokser. New York: Pilgrim Press, 1993.

Singer, Irving. The Pursuit of Love. Baltimore: John Hopkins University Press, 1994.

Smith, Huston. The World's Religions: Our Great Wisdom Traditions. San Francisco: HarperCollins, 1991.

Smith, Quentin. The Felt Meanings of the World: A Metaphysics of Feeling. West Lafayette, IN: Purdue University Press, 2005.

Solomon, Robert C. The Passions. Garden City, NY: Anchor Press, 1976.

---. "What is a 'Cognitive Theory' of the Emotions?" In Philosophy and the Emotions, edited by Anthony Hatzimoysis, 1-18. Cambridge: Cambridge University Press, 2003.

---. "Emotions, Thoughts, and Feelings: Emotions as Engagements with the World." In 
Thinking About Feeling, edited by Robert Solomon 76-90. Oxford: Oxford University Press, 2004.

---. True to Our Feelings: What Our Emotions Are Really Telling Us. Oxford: Oxford University Press, 2006.

---. “The Many Dimensions of Religious Emotional Experience." In Religious Emotions: Some Philosophical Explorations, edited by Willem Lemmens and Walter Van Herck, 230-246. Cambridge: Cambridge Scholars Publishing, 2008.

de Souse, Ronald. The Rationality of Emotions. Cambridge: Massachusetts Institute of Technology Press, 1987.

---. “The Rationality of Emotions." In Explaining Emotions, edited by Amelie Rorty. Berkley, CA: University of California Press, 1980.

Stocker, Robert with Elizabeth Hegeman. Valuing Emotions. Cambridge: Cambridge University Press, 1996.

Stump, Eleonore. Aquinas. London and New York: Routledge, 2003.

---. "Love, By All Accounts." Proceedings and Addresses of the American Philosophical Association 80 (2006): 25-53.

---. "The Non-Aristotelian Character of Aquinas' Ethics: Aquinas on the Passions." Faith and Philosophy 82 (2011): 29-43.

Taylor, Charles. Sources of the Self: The Making of the Modern Identity. Cambridge, MA: Harvard University Press, 1989.

Terruwe MD, Anna A. and Conrad W. Baars MD. Loving and Curing the Neurotic: A New Look at Emotional Illness. New Rochelle, NY: Arlington House, 1972. Thomas Aquinas. Summa Theologiae. Translated by Fathers of the English Dominican 
Province. New York: Benziger Brothers, 1948.

Thomas Aquinas. Summa Theologiae: A Concise Translation. Edited and Translated by

Timothy McDermott. Notre Dame, IN: Ave Maria Press, 1991.

Thomas Aquinas. Questiones Disputatae de Veritate, translated by Robert W. Mulligan,

S. J. Chicago: Henry Regnery Company, 1952.

---. Truth. Translated by James V. McGlynn. Indianapolis, IN: Hackett, 1994.

---. “Emotions and Love.” In An Aquinas Reader. Edited by Mary T. Clark. New York:

Fordham University Press, 2000.

Tillich, Paul. The Dynamics of Faith. New York: Harper Row, 1957.

Tunzin, Donald F. The Voice of Tambaran: Truth and Illusion in Ilahita Arapesh

Religion. Berkeley: University of California Press, 1980.

de Vidas, Elijah. Reshit Hochma. Poland: Beyozefof, 1868.

Wiesel, Elie. "The Holocaust: Elie Wiesel on the Trail of God." In The World's Wisdom, edited by Philip Novak, 224. New York: HarperCollins Publishers, 1994.

Wittgenstein, Ludwig. “A Lecture on Ethics.” The Philosophical Review 74 (1965): 3-12.

Wittgenstein, Ludwig. Tractatus Logico-Philosophicus, translated by D. F. Pears and B.

F. McGuiness. London and New York: Routledge, 1961.

Wolterstorff, Nicholas. "Art and the Aesthetic: The Religious Dimension.” In The

Blackwell Guide to Aesthetics. Edited by Peter Kivy. Malden, MA: Blackwell

Publishing, 2004.

Wynn, Mark. Emotional Experience and Religious Understanding. Cambridge,

Cambridge University Press, 2005.

Zangwill, Nick. "The Myth of Religious Experience.” Religious Studies 40 (2004): 1-22. 


\title{
CURRICULUM VITAE
}

\section{John K. Dryden, Jr.}

\author{
4003 Massie Ave. \\ Louisville, KY 40207 \\ 502-548-1160 \\ johnnydrydenjr@gmail.com
}

\section{EDUCATION}

Ph.D., Humanities, University of Louisville, Louisville, KY, May 2013

Dissertation: "The Feeling of Faith: A Thomistic Approach to Religious Emotions" Advisor: Dr. Robert Kimball

Committee Members: Dr. Thomas Maloney and Dr. Mary Ann Stenger

M.A., Humanities, University of Louisville, Louisville, KY, December 2003

Thesis: "The Epistemological Problem of Religious Diversity: A Critical Analysis of John Hick's Pluralistic Philosophy"

B.A., Philosophy, University of Louisville, Louisville, KY, December 2000

\section{AREAS OF INTEREST}

Specialization: Comparative Religion, Religion and Emotion

Competence: Philosophy of Religion, Ethics, Philosophy of Emotion

\section{PUBLICATIONS}

"The Epistemological Problem of Religious Diversity" in Society for the Advancement of American Philosophy Conference Proceedings. (2004).

\section{CONFERENCE PRESENTATIONS}


"The Feeling of Faith: Aquinas's 'Treatise on the Passions' and Religious Emotions," Wesleyan Philosophical Society Annual Conference, Trevecca Nazarene University, Nashville, TN, March 1, 2012.

"False Hope: Cognition and Emotions in Plato's Philebus," Midsouth Philosophy Conference, University of Memphis, Memphis, TN, March 4, 2011.

Commentary on Lenard Ferry's "Pseudo-Passions: Needless Categorization or Insightful Distinction?," Midwest Conference of the Society for Christian Philosophers, Hope College, Holland, MI, February 25, 2011.

"Gathering the Waters: An Ecocritical Comparison of John Calvin's Theology of Creation and Shakespeare's The Tempest," Massachusetts Center for Renaissance Studies Graduate Conference, University of Massachusetts, Amherst, MA, October 2, 2010.

"Revisions of Pragmatism: Truth in Virginia Woolf's To The Lighthouse," Humanities Graduate Student Colloquium, University of Louisville, Louisville, KY, April 16, 2010.

"Good Grief: The Value of Sorrow," Graduate Research Symposium, University of Louisville, Louisville, KY, March 5, 2010.

"Religious Experience, Expression, and Mystery in The Violent Bear It Away" Humanities Graduate Student Colloquium, University of Louisville, Louisville, KY, April 3, 2009.

"Aquinas' Theory of Faith: Advantages and Challenges of a Thomistic Religious Epistemology," Graduate Research Symposium, University of Louisville, Louisville, KY, March 6, 2009.

“The Epistemological Problem of Religious Diversity," 31st Annual Conference of the Society for the Advancement of American Philosophy, University of Alabama Birmingham, Birmingham, AL, March 4-6, 2004.

“The Epistemological Problem of Religious Diversity," Intermountain West Student Philosophy Conference, University of Utah, Salt Lake City, UT, February 26-28, 2004.

\section{TEACHING EXPERIENCE}

Instructor, Philosophy/Religious Studies, Elizabethtown Community and Technical College, 2012-present.

Graduate Teaching Assistant in Humanities, University of Louisville, 2010 - 2011.

Adjunct Professor of Philosophy, Spalding University, 2006 - present.

Adjunct Professor of Humanities, City Colleges of Chicago, 2004-2006.

\section{AWARDS}

Graduate Teaching Assistant, University of Louisville. 2010-2012.

\section{COURSES TAUGHT}




\section{Elizabethtown Community and Technical College}

Comparative Religions, Spring 2012 - Present

Introduction to Philosophy, Spring 2012 - Present

Ethics, Spring 2012 - Present

University of Louisville (Graduate Teaching Assistant, 2010-2012)

Introduction to World Religions, Fall 2010 - 2012

Introduction to the Study of Religion, Spring 2008

Spalding University (Adjunct Professor, 2006 - present)

Introduction to Ethics, Fall 2006 - Present

Logic, Fall 2007 - Present

Philosophy of the Person, Spring 2011

City Colleges of Chicago (Adjunct Instructor, 2004-2006)

Philosophy, Music, and Drama (Harold Washington College), Fall 2004 - Spring 2006

Art and Philosophy on the African Continent (Harold Washington College), Spring 2006

Introduction to Humanities (Harold Washington College), Spring 2006

Comparative Mythology (Malcolm X College), Fall 2005

Classical Culture (Malcolm X College), Fall 2005

Contemporary Culture (Malcolm X College), Fall 2004 - Spring 2005

\section{SERVICE AND MEMBERSHIPS}

Humanities Colloquium Organizer: University of Louisville, 2010-2011

Member of American Philosophical Association

Member of American Academy of Religion 